\title{
State ownership, bank loans, and corporate investment
}

Article

Accepted Version

Zeng, Y. and Jiang, W. (2014) State ownership, bank loans, and corporate investment. International Review of Economics and Finance, 32. pp. 92-116. ISSN 1059-0560 doi: https://doi.org/10.1016/j.iref.2014.01.009 Available at https://centaur.reading.ac.uk/58510/

It is advisable to refer to the publisher's version if you intend to cite from the work. See Guidance on citing.

Published version at: http://www.sciencedirect.com/science/article/pii/S1059056014000100

To link to this article DOI: http://dx.doi.org/10.1016/j.iref.2014.01.009

Publisher: Elsevier

All outputs in CentAUR are protected by Intellectual Property Rights law, including copyright law. Copyright and IPR is retained by the creators or other copyright holders. Terms and conditions for use of this material are defined in the End User Agreement.

\section{www.reading.ac.uk/centaur}

\section{CentAUR}

Central Archive at the University of Reading

Reading's research outputs online 


\title{
State ownership, bank loans, and corporate investment ${ }^{\text {th }}$
}

\author{
Wei Jiang ${ }^{\mathrm{a}, \mathrm{c}, *}$, Yeqin Zeng ${ }^{\mathrm{b}, 1}$ \\ a Accounting Department, Jinan University, Guangzhou 510632, China \\ b ICMA Centre, Henley Business School, University of Reading, Reading, Berkshire RG6 6BA, UK \\ c Center for Management Accounting Research, Jinan University, Guangzhou 510632, China
}

\section{A R T I C L E I N F O}

Available online $\mathrm{xxxx}$

\section{Keywords:}

Leverage

Underinvestment

Overinvestment

State-owned banks

Disciplining role

\begin{abstract}
A B S T R A C T
We study the effect of bank loans on Chinese publicly listed firms' investment decisions based on the underinvestment and overinvestment theories of leverage. Evidence from China is of particular importance because China is the world's largest emerging and transitional economy. At first we show that there is a negative relationship between bank loan ratios and investment for Chinese publicly listed firms. And this negative relationship is much stronger for firms with low growth than firms with high growth. Secondly, we find that both short-term and longterm loan ratios are negatively correlated with investment. However, the higher the long-term loan ratios are, the weaker the negative relationship between long-term loan ratios and investment is. Thirdly, firm ownership only matters to the effect of short-term bank loans on investment in our sample. That is, the negative relationship between short-term loan ratios and investment is weaker for SOEs than for non-SOEs. Lastly, we show that the reform of China's banking system in 2003 has not strengthened the negative relationship between bank loans and investment. Our findings suggest that although Chinese state-owned banks are severely intervened by government policies, they still have a disciplining role on firms' investment, especially in firms with low growth.
\end{abstract}

(c) 2014 Elsevier Inc. All rights reserved.

\section{Introduction}

Theoretical and empirical studies have extensively investigated the impact of a firm's financial leverage on its investment decisions. Two different outcomes are documented. The first is an underinvestment problem (Myers, 1977): managers of highly levered firms are forced to give up positive net present value (NPV) projects because of debt overhang. Therefore, firms with high leverage are less likely to explore valuable growth opportunities than firms with low leverage. The second is discussed by Jensen (1986) and Stulz (1990). They argue that high leverage prevents the misuse of free cash flow by firm managers. Debt holders perform disciplining and monitoring roles in firms with low growth and high leverage, alleviating the overinvestment problem.

The majority of previous studies only focus on developed economies. Denis and Denis (1993), Lang et al. (1996), and Ahn et al. (2006) find that leverage and investment are negatively correlated for U.S. firms. They also show that the negative relationship is

\footnotetext{
is We thank Shijun Cheng, Jarrad Harford, Hongtao Shen, the two anonymous referees and the participants at the First Global Chinese Management Studies Conference (2011) for their helpful comments and discussions. Jiang acknowledges the financial support from the National Natural Science Foundation of China (71032006, 71272212), the Humanities and Social Science Foundation of the Ministry of Education of China (11YJC630076), the Humanities and Social Science Foundation of the Higher Education Institution of Guangdong Province, China (11WYXM011), and the Fundamental Research Funds for the Central Universities at Jinan University (12JNYH003).

* Corresponding author. Tel.: + 8613760883968.

E-mail addresses: tweijiang@jnu.edu.cn (W. Jiang), y.zeng@icmacentre.ac.uk (Y. Zeng).

${ }^{1}$ Tel.: + 441183788239 .
}

1059-0560/\$ - see front matter @ 2014 Elsevier Inc. All rights reserved. http://dx.doi.org/10.1016/j.iref.2014.01.009 
much stronger for firms with low growth than for firms with high growth. Aivazian et al. (2005) also find similar evidence by using Canadian firm data. These researchers support the overinvestment theory. However, other empirical studies (See, e.g., Gaver \& Gaver, 1993; Goyal et al., 2002; Jung et al., 1996; Smith \& Watts, 1992) use U.S. firm data and provide evidence that supports the underinvestment theory. The empirical findings for developed economies may not be generalized and applied to developing economies. In developed economies, banks and public debt markets provide most of the corporate debt financing. Both banks and other corporate bond holders seek maximized risk-adjusted returns on their investment. While in developing economies, public debt markets are usually nascent and commercial banks are usually controlled by governments.

According to the International Monetary Fund's World Economic Outlook Report, 154 countries were considered as emerging and developing economies by October 2009. ${ }^{2}$ These economies share some similarities: their stock markets and public debt markets are usually at premature stages; most private investors do not have substantial wealth; and state-owned banks control nearly all of the free capital in financial markets. Bank loans are the major, and sometimes the only, source of external financing for firms in developing economies. Furthermore, the lending decisions of most state-owned banks are severely intervened by state governors and their macroeconomic policies. Risk-adjusted returns are not the primary concern of state-owned banks.La Porta et al. (2002), Sapienza (2004), Dinc (2005), and Khwaja and Mian (2005) all show that state-owned banks serve mainly political and personal purposes of politicians, such as their successes in elections and bailing out poorly performing firms. Therefore, the monitoring and disciplining roles of state-owned banks are compromised in developing economies. We should not take the overinvestment theory of leverage documented in developed economies for granted when studying the relationship between leverage and investment in developing economies.

In this paper, we examine the relationship between bank loans and firm investment by using Chinese publicly listed firm data. Evidence from China is of particular importance given that China is the world's largest emerging and transitional economy. China has maintained high economic growth during the past 30 years since it opened up its economy to foreign countries in 1978 . However China's economic rise has not been well explained. Neither the stock markets nor the public corporate bond markets are well developed in China. The Shanghai Stock Exchange ${ }^{3}$ reopened in 1990 after it ceased in 1941. Chinese individual investors still cannot invest directly in corporate bonds. Only a small part of large state-owned firms have received approval from the Chinese National Development and Reform Commission (NDRC) to issue public corporate bonds. Private funds in China are only at the preliminary stage. The main source of external finance for most Chinese firms is to borrow from banks.

One unique feature of China's banking industry is that more than $98 \%$ of the banking assets are under the control of the Chinese Government (Barth et al., 2004). Therefore, we follow Firth et al. (2008) and take all bank loans on the balance sheets of Chinese publicly listed firms as state-owned bank loans. Furthermore, we can divide all publicly listed firms within our sample into two subgroups by firm ownership: state-owned enterprises (SOEs, thereafter) and non-state-owned enterprises (non-SOEs, thereafter). ${ }^{4}$ The former is formed in the process of SOEs' corporatization reform, and the latter is formed either through the acquisition of non-tradable shares from large state shareholders by private investors during firm restructuring processes or through direct IPOs. Brandt and Li (2003) and Ge and Qiu (2007) find that Chinese state-owned banks are more likely to provide loans to SOEs due to political concerns, such as improving the employment rate and enhancing social stability. State-owned banks only seek to maximize their risk-adjusted returns when they offer loans to non-SOEs. Since state-owned banks have different incentives when they lend to SOEs and non-SOEs, the homogeneity of bank ownership and the heterogeneity of listed firms in China provide us with a great opportunity to investigate the relationship between leverage and investment.

In their recent work, Firth et al. (2008) examine the impact of financial leverage on investment in Chinese publicly listed firms. They find a negative relationship between leverage and investment. What is more, this negative relationship is weaker for firms with low growth opportunities, poor operating performance, and a high level of state shareholdings. The results of Firth et al. (2008) are partly consistent with prior studies in developed economies and support the underinvestment theory. Our paper extends Firth et al. (2008)'s study in three dimensions. First of all, Firth et al. (2008) take all Chinese publicly listed firms in their sample as SOEs. But 34\% of the firms in our sample are non-SOEs. We are able to investigate the roles of leverage on investment within SOEs sample and non-SOEs sample separately. Secondly, we are able to divide bank loans by the loans' term structure and compare the roles of short-term loans and long-term loans on firms' investment. This method is seldom explored in previous studies. China has a premature public corporate bond market and a weak legal system, so it is the short-term loan that provides the major external financing for Chinese firms. This feature is rarely observed in developed countries (Rajan \& Zingales, 1995) or most of the other developing countries (Booth et al., 2001). Thirdly, we examine the effect of China's banking reform in 2003 on the relationship between bank loans and investment. The stated goal of the reform is to "transform major banks into internationally competitive joint-stock commercial banks with appropriate corporate governance structures, adequate capital, stringent internal controls, safe and sound business operations, quality services as well as desirable profitability" (Kudrna, 2007). It is interesting to test whether this reform has successfully enhanced the monitoring and disciplining roles of Chinese state-owned banks.

After mitigating the potential endogeneity problem between bank loans and investment, we have the following four major findings. At first, there is a negative relationship between bank loan ratios and investment for Chinese listed firms and this correlation is much stronger for firms with low growth. This finding is consistent with the evidence in developed economies but

\footnotetext{
2 Cuba and North Korea are not included in the emerging and developing countries.

3 The Shanghai Stock Exchange is one of the two stock exchanges in Mainland China. The other one is the Shenzhen Stock Exchange, which is relatively smaller than the Shanghai Stock Exchange.

${ }^{4}$ Non-SOEs include domestic private firms, joint ventures, and foreign private firms.
} 
against Firth et al. (2008) who show that the negative relationship between leverage and investment is weaker for firms with low growth. Secondly, we find that both short-term and long-term loan ratios are negatively correlated with investment, and that both correlations are stronger for firms with low growth. Thirdly, the higher the long-term loan ratios, the weaker the negative relationship between firms' long-term loan ratios and their investment. Furthermore, the negative relationship between firms' short-term loan ratios and investment is weaker for SOEs than for non-SOEs. The relationship between long-term loan ratios and their investment does not differ significantly between SOEs and non-SOEs. Lastly, although the Chinese government implemented the banking system reform in 2003, the negative relationship between bank loans and investment has not been strengthened yet. Overall, our results suggest that Chinese banks still have a disciplining role even though China's banking system is dominated by state-owned banks. The disciplining role is mainly imposed through short-term loans, rather than long-term loans. In addition, the state-owned banks impose a weaker disciplining role in SOEs than in non-SOEs. The disciplining roles of the state-owned banks in both SOEs and non-SOEs have not been strengthened since the 2003 banking system reform.

Our studies make four contributions to the existing literature. At first, consistent with the findings in the U.S. and Canada, we show that loans by Chinese state-owned banks also have a disciplining role in firms with low growth opportunities. Because the state ownership of banks is common in countries other than the United States (La Porta et al., 2002) and state-owned banks have dominating power in China, our findings constitute one valuable extension to the existing literature, and suggest that we cannot simply ignore the positive contribution of Chinese state-owned banks to Chinese publicly listed firms' corporate governance.

Secondly, we contribute to the empirical literature on the role of short-term debt. Our study shows that Chinese state-owned banks mainly use short-term loans to alleviate the overinvestment problem in low growth firms. This result not only provides direct empirical evidence on the monitoring role of short-term debt (Diamond, 1984; Rajan, 1992), but also provides indirect empirical evidence for the bank lending theory (Diamond, 2004).

Thirdly, we contribute to the empirical literature on the role of state-owned banks. Most previous studies only focus on the dark side of state-owned banks, such as serving political election purposes (Dinc, 2005; Khwaja \& Mian, 2005; Sapienza, 2004) and bailing out poorly performing firms (Cull \& Xu, 2003; Park \& Sehrt, 2001). Our study shows that even though Chinese banks are mostly state owned and subjected to political interventions, they still partly fulfill their disciplining role in Chinese firms. This bright side of state-owned banks has seldom been documented in the previous literature.

And the last contribution is that we extend and complete the empirical literature on the reforms of China's banking system. Both Fu and Heffernan (2009) and Lin and Zhang (2009) document that the reforms of China's banking system in the late 1990s and the early 2000s have little impact on banks' efficiency. Only Berger et al. (2009) show that minority foreign ownership of the "Big Four" state-owned banks actually improves banks' efficiency. All of the above studies examine the effects of China's banking reforms on banks' performance. Our study focuses on the effect of the 2003 banking reform on the relation between bank loans and firm investment. Therefore, our study provides a new perspective and extends the existing literature.

The rest of the paper is organized as follows. In Section 2, we review the related literature and introduce the background of China's banking system. Section 3 develops our hypotheses. In Section 4, we describe the sample and variable definition. In Section 5, we elaborate the regression models. Section 6 discusses the empirical results and other robustness tests. Section 7 concludes.

\section{Literature review and the introduction to China's Banking system}

\subsection{Prior evidence on leverage, growth opportunities, and investment}

Modigliani and Miller (1958)'s leverage irrelevance theory is based on their utopian assumption that the financial market is frictionless and complete. In their model, a firm with good investment opportunities is able to obtain external funding from either debt or equity financing. Modigliani and Miller's conclusion has been challenged many times because the real world is far from perfection. Due to different types of friction, both the underinvestment and the overinvestment theories are proposed in the previous literature. Because high leverage constrains investment for firms with high growth, the underinvestment theory suggests that firms with good growth opportunities keep lower leverage to avoid missing positive NPV projects in the future. However, the overinvestment theory predicts that high leverage prevents firm managers from abusing free cash flows, especially for firms with low growth. Empirical evidence for both the underinvestment and the overinvestment theories is documented in the previous literature.

Consistent with the prediction of the underinvestment theory, Smith and Watts (1992) and Gaver and Gaver (1993) find that firms with high growth prospects have significantly lower leverage. Similarly, Jung et al. (1996) find that firms with valuable investment opportunities are more likely to issue equity when external financing is needed. Goyal et al. (2002) investigate the U.S. defense industry and find that the debt levels of weapon manufacturers increase significantly as their growth opportunities decline.

Consistent with the prediction of the overinvestment theory, Lang et al. (1996) show that there is a negative relationship between leverage and firms' future growth, but this negative relation exists only in firms with low growth. For firms with high growth prospects, leverage does not reduce firms' investment. Recently, Aivazian et al. (2005) use Canadian firm sample and show that there is a negative relation between leverage and investment. The negative effect is significantly stronger for firms with low growth than for firms with high growth. Ahn et al. (2006) also find a negative impact of leverage on investment in diversified firms. In addition, the negative effect is significantly greater for high Tobin's $Q$ than for low Tobin's $Q$ segments and significantly greater for non-core than for core segments. Evidence from leveraged recapitalizations also supports the overinvestment 
theory. Denis and Denis (1993) find a significant reduction in firms' capital expenditures following the increase in leverage. Furthermore, the reduction in capital expenditures is associated with significant increases in the wealth of the recapitalizing firms' shareholders. Peyer and Shivdasani (2001) find that firms allocate more capital to business segments that generate greater cash flows.

Previous studies on firm value support both the underinvestment and the overinvestment theory. McConnell and Servaes (1995) report a negative impact of leverage on the value of firms with high growth, which suggests that higher leverage exacerbates the underinvestment problem and reduces firm value. But the impact of leverage on the value of firms with low growth is positive, which implies that higher leverage attenuates the overinvestment problem and increases the firm value. These two findings show the consistency between the underinvestment theory and the overinvestment theory.

\subsection{Introduction to China's banking system}

China's financial system is dominated by the "Big Four" state-owned commercial banks: the Bank of China (BOC), the Agriculture Bank of China ( $\mathrm{ABC}$ ), the Construction Bank of China ( $\mathrm{CBC}$ ), and the Industrial and Commercial Bank of China (ICBC). In addition to the "Big Four" state-owned commercial banks, there are other financial institutions, such as policy banks, national joint-stock commercial banks, regional commercial banks, and rural credit cooperatives, which play only a minor role in China's financial system. Due to the high household saving rate in China and some historical reasons, Chinese banks hold most of the free capital in the financial market. Investments from private funds are rare. Meanwhile, China's equity and bond markets are relatively small, both in terms of market capitalization and in terms of the total value traded as a percentage of its GDP (Ayyagari et al., 2010). Farrell et al. (2006) report that China's equity market capitalization, excluding non-tradable state-owned shares, is equivalent to $17 \%$ of China's annual GDP. This percentage is much lower than $60 \%$ or more in other emerging markets. In China's bond market, corporate bonds issued by non-financial companies amount to mere $1 \%$ of its GDP, compared with an average of 50\% in other emerging markets. As Dobson and Kashyap (2006) state, China's banking system has the highest share of government ownership in the world (almost 100\%). Virtually all corporate debt borrowings in China have been conducted through state-owned banks.

Allen et al. (2005) point out that the key problem for China's banking system is the non-performing loans of the "Big Four" state-owned commercial banks. They argue that a large fraction of these non-performing loans is borrowed by SOEs, and Chinese banks are forced to lend to SOEs for political or other non-economic reasons. This argument is confirmed by Chinese government officials and other empirical researchers. In 2004, Xiaochuan Zhou, the head of the Chinese central bank, reported that based on a 2003 survey, "30\% of total nonperforming loans of state-owned commercial banks were due to interventions by the central and local government; 30\% were resulted by mandatory credit support to SOEs; $10 \%$ arose from the poor legal environment and weak law enforcement in some regions; $10 \%$ stemmed from industrial restructuring in some enterprises; and the last $20 \%$ originated from the bad operational decisions of the state-owned commercial banks themselves" (Zhou, 2004). Both Park and Sehrt (2001) and Cull and Xu (2003) find that the state-owned banks have become more inefficient in allocating credit since the middle of the 1990s, because state-owned banks have been forced to bail out more and more poorly performing SOEs. Economic fundamentals have had little effect on the total lending decisions made by the state-owned banks. Brandt and Li (2003) show that Chinese state-owned banks discriminate against non-SOEs in their lending decisions for non-profit reasons. As a result, non-SOEs have to look for more expensive alternatives, such as trade credit, for external financing. Ge and Qiu (2007) also demonstrate that because of bank discrimination, non-SOEs have to take more trade credit and are more likely to have overdue trade credit outstanding and long-term trade credit than SOEs.

Although China's banking system is characterized as high state ownership, there have been several reforms in China's banking system in the process of China's economy transition. Especially during the past two decades, banking system reforms aspired to reduce Chinese government intervention. ${ }^{5}$ In 1994, the Chinese government established three specialized "policy" banks: the Agricultural Development Bank of China (ADBC), the China Development Bank (CDB), and the Export-Import Bank of China (Chexim). These three banks aim to reduce the burden of Chinese state-owned commercial banks, such as financing state-directed trades and development projects. In 1995, the Central Bank Law and the Commercial Bank Law were promulgated, in an effort to improve bank lending standards and make bank managers accountable for bank performance. In order to separate the responsibilities of the People's Bank of China (PBOC) from monetary policy and banking supervision, the Chinese Banking Regulatory Commission (CBRC) was created in 2003. The CBRC started to implement risk-based supervision and impose sanctions for infractions. Meanwhile, under the commitments of the World Trade Organization (WTO) agreement, China allows foreign investors to purchase shares in the state-owned banks and encourages foreign banks to compete with Chinese banks. In 2003, most provinces in China opened their domestic currency market to foreign banks. Also in 2003, the CBRC updated the guidelines for foreign investors and raised the purchase limit to $25 \%$ of any domestic bank's shares. ${ }^{6}$ Furthermore, aiming to improve the governance of state-owned commercial banks and their performance, the Chinese government restructured the "Big Four" state-owned commercial banks by cleaning-up non-performing loans and public capital injections. The "Big Four" began to take IPOs on foreign stock exchanges. As a result, in October 2005, the CBC took an IPO in Hong Kong and the BOC followed in June 2006; in October 2006, the ICBC took its IPO in Hong Kong; the last was ABC, which went public in Shanghai and Hong Kong on July 15 and 16, 2010.

\footnotetext{
5 See Alicia et al. (2006), Dobson and Kashyap (2006), and Kudrna (2007) for more details of China's banking system reforms.

6 The purchase limit for individual investors is $20 \%$.
} 


\section{Hypotheses}

Based on the unique features of China's banking system and the previous studies on the relationship between leverage and investment, we expect that Chinese state-owned banks have a disciplining role on firms' investment to some extent, and are able to alleviate firms' overinvestment problem. ${ }^{7}$ However, because of the soft budget constraints on SOEs during the transition of the Chinese economy (Kornai et al., 2003), Chinese state-owned banks are more likely to bail out SOEs than non-SOEs for maintaining the employment rate and social stability if both types of firms fall into financial distress (Chow et al., 2010). We also expect that the disciplining role of the state-owned banks on overinvestment may be weaker in SOEs than in non-SOEs. Therefore, we develop the first hypothesis:

- Hypothesis 1a. There is a negative relationship between firms' bank loan ratios and their investment.

- Hypothesis 1b. The negative relationship between firms' bank loan ratios and their investment is weaker for SOEs than for non-SOEs.

Levine (1997) argues that financial intermediaries, such as banks, have the advantage of acquiring information and monitoring firm managers. On the one hand, individual lenders lack the time, capacity, and resources to collect and process reliable information on firms and managers. While banks are endowed with economies of scale and are able to economize the costs of acquiring and processing information. On the other hand, individual lenders do not have an incentive to monitor firm managers because of the free-rider problem (Diamond, 1984). While banks can not only reduce the costs of acquiring information ex ante, but also mitigate the costs of monitoring firm managers and exerting corporate control ex post. The benefit of monitoring usually outweighs the cost of monitoring for large investors like banks. In addition, short-term loans may facilitate the comparative advantages of banks in acquiring information and monitoring managers, because short-term loans can be readily accessed and easily renegotiated (Rajan, 1992). ${ }^{8}$ These suggest that banks have a comparative advantage in using short-term loans to exercise their disciplining role. Given the state ownership of Chinese banks and their soft budget constraints on SOEs (Chow et al., 2010; Kornai et al., 2003), we expect that the disciplining role of short-term loans on overinvestment may be weaker in SOEs than in non-SOEs. Therefore, we formulate the second hypothesis:

- Hypothesis 2a. There is a negative relationship between firms' short-term loan ratios and their investment.

- Hypothesis $\mathbf{2 b}$. The negative relationship between firms' short-term loan ratios and their investment is weaker for SOEs than for non-SOEs.

When applying the law-finance-growth nexus to China, Allen et al. (2005) demonstrate that China's legal system is significantly less developed than most of the countries in La Porta et al.'s (1997) and Levine's (2002) samples. Diamond (2004) points out that in a legal system with expensive or ineffective contract enforcement, it is difficult to induce lenders to enforce debt contracts ex post. Short-term loans can not only provide the comparative advantages in acquiring information and monitoring managers (Diamond, 1984; Rajan, 1992) but also serve as a commitment device that provides incentives for each short-term lender to enforce his contract (Diamond, 2004); therefore banks have incentives to provide short-term loans rather than long-term loans ex ante. Consistent with Diamond's (2004) theory, Demirguc-Kunt and Maksimovic (1999), Giannetti (2003), Qian and Strahan (2007), and Delcoure (2007) show that firms in countries with weaker legal systems have lower long-term debt ratios. With the immature public corporate bond market, it is not easy for Chinese firms to obtain long-term loans even from state-owned banks. Huang and Song (2006), Bhabra et al. (2008), and Li et al. (2009) show that only large firms with substantial fixed assets can obtain long-term loans in China. ${ }^{9}$ The above discussions suggest that Chinese state-owned banks may be more cautious about supplying long-term loans than short-term loans. When banks do supply long-term loans, they usually impose stricter lending and monitoring criteria or simply are dictated by the Government regardless of firms' performance. If the former case is true, we should expect that long-term loans lent by state-owned banks also serve a disciplining purpose. However, because of the banks in China being state owned and placing soft budget constraints on SOEs (Chow et al., 2010; Kornai et al., 2003), the disciplining role of long-term loans on overinvestment may be weaker in SOEs than in non-SOEs. Therefore, we formulate the third hypothesis:

- Hypothesis 3a. There is a negative relationship between firms' long-term loan ratios and their investment.

- Hypothesis 3b. The negative relationship between long-term loan ratios and investment is weaker for SOEs than for non-SOEs.

\footnotetext{
${ }^{7}$ Fu and Heffernan (2009) and Lin and Zhang (2009) show that China's banking reform during the period of 1994 to 2004 has not improved the efficiency and performance of state-owned banks. In this case, we may not observe a disciplining role.

${ }^{8}$ Hart and Moore (1995) point out that non-postponable short-term debt forces firm managers to disgorge funds that they might otherwise use to make unprofitable but empire-building investments.

9 Huang and Song (2006) and Bhabra et al. (2008) report that the average levels of long-term debt ratios for Chinese publicly listed firms are about 8\% (scaled by book value of total assets) or 3\% (scaled by market value of total assets), which are lower than those in developed countries (Rajan \& Zingales, 1995) and lower than those in developing countries (Booth et al., 2001).
} 
In the above discussion, we argue that as China has a premature public corporate bond market, the major external finance for Chinese firms is provided by the short-term loans, not the long-term loans. Rajan (1992) indicates that state-owned banks have a comparative advantage in using short-term loans rather than long-term loans to exercise their disciplining role. In addition, with the weak legal system in China, state-owned banks have incentives to provide short-term loans rather than long-term loans to enforce their contracts (Diamond, 2004). As a result, the negative relation between bank loan ratios and investment would be weaker when the long-term loan ratios in firms' total bank loans are higher. Therefore, we formulate the forth hypothesis:

- Hypothesis 4. The higher the long-term loan ratios in firms' total bank loans are, the weaker the negative relationship between firms' bank loan ratios and their investment is.

\section{Data source and summary statistics}

We collect financial and stock price data from the China Stock Market and Accounting Research (CSMAR) database. To obtain a sample of publicly listed firms, we include all the firms listed on the Shanghai Stock Exchange and Shenzhen Stock Exchange during 2000-2011. Firms' ownership data are collected from the SinoFin database developed by the China Center for Economic Research (CCER). The SinoFin database can identify the ultimate controllers of firms as SOEs or non-SOEs. We exclude firms from our sample according to these criteria: financial services firms that make the sample heterogeneous; firms for which we cannot identify their ultimate controllers; and firms that do not have at least 3 years' consecutive sales growth data. To deal with outlier observations, we use $95 \%$ winsorization.

There are 10,451 firm-year observations in our filtered sample. Table 1 presents the descriptive statistics for our sample over the period 2000-2011. ${ }^{10}$ Panel A shows the summary statistics for the total sample: the mean (median) of bank loan ratios is $0.242(0.238)$; the mean (median) of short-term loan ratios is 0.181 (0.169); the mean (median) of long-term loan ratios is only $0.061(0.020)$; the mean (median) of loan maturity ratios is only $0.223(0.122)$, suggesting that Chinese publicly listed firms indeed rely more on short-term loans than long-term loans ${ }^{11}$; the sample mean (median) of Tobin's Q is 1.678 (1.397); and the mean (median) of sales growth rates is $0.229(0.160)$. In our sample, the average Tobin's $Q$ is higher than that reported by Firth et al. (2008) (1.231 and 1.048, respectively), while the average growth rate is lower ( 0.432 and 0.278 , respectively). In our sample, $34 \%$ of firms are identified as non-SOEs, so we are able to compare banks' lending between SOEs and non-SOEs.

Panel B and Panel C of Table 1 show the summary statistics for SOEs and non-SOEs, respectively. In the sample of SOEs, the mean (median) of bank loan ratios is 0.241 (0.235); the mean (median) of short-term loan ratios is $0.174(0.162)$; the mean (median) of long-term loan ratios is only 0.067 (0.026); and the mean (median) of loan maturity ratios is 0.242 (0.149). In the sample of non-SOEs, the mean (median) of bank loan ratios is 0.244 (0.241); the mean (median) of short-term loan ratios is 0.193 (0.184); the mean (median) of long-term loan ratios is only 0.051 (0.010); and the mean (median) of loan maturity ratios is 0.186 (0.070). In general, these statistics suggest that short-term debt financing is more popular than long-term debt financing in China. Moreover, non-SOEs depend more (less) on short-term (long-term) loans than SOEs.

Table 2 presents the correlation matrix of all the variables used in our regression models. The bank loan ratio and short-term loan ratio are negatively and significantly correlated with investment, which provides preliminary evidence to support our hypotheses. However, the long-term loan ratio and investment are significantly positively correlated. Consistent with the prior studies, the control variables, which include Tobin's Q growth rate, cash flow, sales, profitability, and firm size, are all positively and significantly related to investment. The details of all key variables are included in the Appendix A.

\section{Regression model specifications}

In this paper, we study the effect of bank loans on investment for Chinese publicly listed firms. The investment regression models we estimate resemble those of Aivazian et al. (2005), Ahn et al. (2006), and Firth et al. (2008):

$$
\begin{aligned}
\text { Investment }_{\mathrm{i}, \mathrm{t}}= & \beta_{0}+\beta_{1} \text { Debt }_{\mathrm{i}, \mathrm{t}-1}\left(\text { or Sdebt }_{\mathrm{i}, \mathrm{t}-1} \text { Ldebt }_{\mathrm{i}, \mathrm{t}-1}\right)+\beta_{2} \mathrm{Q}_{\mathrm{i}, \mathrm{t}-1}\left(\text { or Growth }_{\mathrm{i}, \mathrm{t}}\right)+\beta_{3} \text { Topshare }_{\mathrm{i}, \mathrm{t}} \\
& +\beta_{4} \text { Director }_{\mathrm{i}, \mathrm{t}}+\beta_{5} \text { Indepen }_{\mathrm{i}, \mathrm{t}}+\beta_{6} \text { Bsize }_{\mathrm{i}, \mathrm{t}}+\beta_{7} \text { CEOage }_{\mathrm{i}, \mathrm{t}}+\beta_{8} \text { CEOtenure }_{\mathrm{i}, \mathrm{t}} \\
& +\beta_{9} \text { CEOshare }_{\mathrm{i}, \mathrm{t}}+\beta_{10} \text { CF }_{\mathrm{i}, \mathrm{t}}+\beta_{11} \text { Sales }_{\mathrm{i}, \mathrm{t}-1}+\beta_{12} \text { Roa }_{\mathrm{i}, \mathrm{t}}+\beta_{13} \text { Size }_{\mathrm{i}, \mathrm{t}}+\beta_{14} \text { Market }_{\mathrm{i}, \mathrm{t}}+\varepsilon_{\mathrm{i}, \mathrm{t}}
\end{aligned}
$$

In Regression 1, Investment $t_{i, t}$ is defined as the ratio of net capital expenditure of firm $i$ at time $t$ to lagged fixed assets, and the capital expenditure includes both fixed assets and construction in progress ${ }^{12}$; Debt $_{\mathrm{i}, \mathrm{t}-1}$ is the bank loan ratio, defined as the lagged

\footnotetext{
${ }^{10}$ Although we choose 2000 as the starting year, we need to use financial data going back to 1998 in order to generate the change variables. In 1998 , Chinese publicly listed firms adopted new generally accepted accounting principles (GAAP). Chinese GAAP applies to all publicly listed firms regardless of firm ownership. Prior to 1998, the financial statement data of Chinese publicly listed firms are less consistent both cross-sectionally and in relation to time series.

11 Our sample includes 10,451 firm-year observations. 3793 observations have no long-term loans, of which 2311 observations are SOEs and 1482 observations are non-SOEs. Our results are robust if we delete the observations without long-term loans.

12 Before 2007, the Chinese accounting standards did not require a separate disclosure of R\&D, so we do not include this form of expenditure. We also consider the definition of Chen et al. (2011), which measures the capital expenditure as cash payments for fixed assets, intangible assets, and other long-term assets from the cash flow statement minus cash receipts from selling these assets, and find similar results.
} 
Table 1

Summary statistics.

\begin{tabular}{|c|c|c|c|c|c|c|}
\hline Variables & Obs. & Mean & Median & Min. & Max. & Std. \\
\hline \multicolumn{7}{|c|}{$\begin{array}{l}\text { Panel A. Total sample. This table shows the summary statistics of the variables which we use in the regression models. The sample includes all the } \\
\text { observations in our refined data set and the sample period is from } 2000 \text { to } 2011 \text {. }\end{array}$} \\
\hline Investment & 10,451 & 0.1068 & 0.0385 & -0.2786 & 0.9411 & 0.2351 \\
\hline Debt $_{t-1}$ & 10,451 & 0.2419 & 0.2375 & 0.0000 & 0.5686 & 0.1542 \\
\hline Sdebt $_{\mathrm{t}-1}$ & 10,451 & 0.1806 & 0.1690 & 0.0000 & 0.4753 & 0.1273 \\
\hline Ldebt $_{t-1}$ & 10,451 & 0.0613 & 0.0203 & 0.0000 & 0.3285 & 0.0835 \\
\hline $\mathrm{DM}_{\mathrm{t}-1}$ & 10,451 & 0.2231 & 0.1216 & 0.0000 & 1.0000 & 0.2620 \\
\hline Nature & 10,451 & 0.3370 & 0.0000 & 0.0000 & 1.0000 & 0.4727 \\
\hline$Q_{t-1}$ & 10,451 & 1.6776 & 1.3966 & 0.9766 & 4.4187 & 0.7750 \\
\hline Growth & 10,446 & 0.2293 & 0.1603 & -0.3214 & 1.6496 & 0.3592 \\
\hline Topshare & 10,451 & 0.3889 & 0.3667 & 0.1245 & 0.7186 & 0.1609 \\
\hline Director & 10,451 & 0.1348 & 0.0000 & 0.0000 & 1.0000 & 0.3415 \\
\hline Indepen & 10,451 & 0.3112 & 0.3333 & 0.0000 & 0.8000 & 0.1161 \\
\hline Bsize & 10,451 & 2.2184 & 2.1972 & 1.7918 & 2.7080 & 0.2022 \\
\hline CEOage & 10,451 & 3.8196 & 3.8286 & 3.5263 & 4.0775 & 0.1392 \\
\hline CEOtenure & 10,451 & 0.8143 & 0.8824 & 0.0000 & 1.5041 & 0.4022 \\
\hline CEOShare & 10,451 & 0.0027 & 0.0000 & 0.0000 & 0.0758 & 0.0129 \\
\hline $\mathrm{CF}$ & 10,451 & 0.1278 & 0.1103 & -0.6920 & 1.0010 & 0.2877 \\
\hline Sales $t-1$ & 10,451 & 2.0799 & 1.3499 & 0.1742 & 9.9737 & 2.1280 \\
\hline Roa & 10,451 & 0.0289 & 0.0311 & -0.1719 & 0.1461 & 0.0580 \\
\hline Size & 10,451 & 21.3609 & 21.2493 & 19.5032 & 23.7757 & 0.9951 \\
\hline Market & 10,451 & 7.5468 & 7.5600 & 0.0000 & 11.8000 & 2.2379 \\
\hline
\end{tabular}

Panel B. SOEs sample. This table shows the summary statistics of the variables which we use in the regression models. The sample includes all the observations of SOEs in our refined data set and the sample period is from 2000 to 2011.

\begin{tabular}{|c|c|c|c|c|c|c|}
\hline Investment & 6945 & 0.1069 & 0.0417 & -0.2787 & 0.9410 & 0.2281 \\
\hline Debt $_{\mathrm{t}-1}$ & 6945 & 0.2407 & 0.2350 & 0.0000 & 0.5686 & 0.1551 \\
\hline Sdebt $t_{t-1}$ & 6945 & 0.1742 & 0.1623 & 0.0000 & 0.4753 & 0.1248 \\
\hline Ldebt $_{\mathrm{t}-1}$ & 6945 & 0.0665 & 0.0256 & 0.0000 & 0.3285 & 0.0868 \\
\hline $\mathrm{DM}_{\mathrm{t}-1}$ & 6945 & 0.2417 & 0.1492 & 0.0000 & 1.0000 & 0.2674 \\
\hline$Q_{t-1}$ & 6945 & 1.6029 & 1.3561 & 0.9766 & 4.4187 & 0.6999 \\
\hline Growth & 6943 & 0.2199 & 0.1602 & -0.3213 & 1.6496 & 0.3295 \\
\hline Topshare & 6945 & 0.4208 & 0.4136 & 0.1245 & 0.7186 & 0.1623 \\
\hline Director & 6945 & 0.1042 & 0.0000 & 0.0000 & 1.0000 & 0.3055 \\
\hline Indepen & 6945 & 0.2980 & 0.3333 & 0.0000 & 0.8000 & 0.1239 \\
\hline Bsize & 6945 & 2.2444 & 2.1972 & 1.7918 & 2.7080 & 0.2044 \\
\hline CEOage & 6945 & 3.8326 & 3.8286 & 3.5264 & 4.0775 & 0.1333 \\
\hline CEOtenure & 6945 & 0.8203 & 0.9163 & 0.0000 & 1.5041 & 0.4042 \\
\hline CEOShare & 6945 & 0.0003 & 0.0000 & 0.0000 & 0.0759 & 0.0036 \\
\hline $\mathrm{CF}$ & 6945 & 0.1310 & 0.1119 & -0.6920 & 1.0010 & 0.2645 \\
\hline Sales ${ }_{t-1}$ & 6945 & 2.0327 & 1.3351 & 0.1743 & 9.9737 & 2.0791 \\
\hline Roa & 6945 & 0.0279 & 0.0299 & -0.1720 & 0.1461 & 0.0554 \\
\hline Size & 6945 & 21.4969 & 21.4064 & 19.5032 & 23.7757 & 0.9975 \\
\hline Market & 6945 & 7.2706 & 7.3000 & 0.0000 & 11.8000 & 2.1398 \\
\hline
\end{tabular}

Panel C. Non-SOEs sample. This table shows the summary statistics of the variables which we use in the regression models. The sample includes all the observations of non-SOEs in our refined data set and the sample period is from 2000 to 2011.

\begin{tabular}{|c|c|c|c|c|c|c|}
\hline Investment & 3506 & 0.1066 & 0.0318 & -0.2787 & 0.9411 & 0.2484 \\
\hline Debt $_{\mathrm{t}-1}$ & 3506 & 0.2444 & 0.2411 & 0.0000 & 0.5686 & 0.1524 \\
\hline Sdebt $_{t-1}$ & 3506 & 0.1933 & 0.1844 & 0.0000 & 0.4753 & 0.1311 \\
\hline Ldebt $_{\mathrm{t}-1}$ & 3506 & 0.0511 & 0.0104 & 0.0000 & 0.3285 & 0.0754 \\
\hline $\mathrm{DM}_{\mathrm{t}-1}$ & 3506 & 0.1861 & 0.0701 & 0.0000 & 1.0000 & 0.2466 \\
\hline$Q_{t-1}$ & 3506 & 1.8255 & 1.4905 & 0.9766 & 4.4187 & 0.8873 \\
\hline Growth & 3503 & 0.2487 & 0.1603 & -0.3214 & 1.6496 & 0.4129 \\
\hline Topshare & 3506 & 0.3260 & 0.2933 & 0.1245 & 0.7186 & 0.1386 \\
\hline Director & 3506 & 0.1950 & 0.0000 & 0.0000 & 1.0000 & 0.3963 \\
\hline Indepen & 3506 & 0.3371 & 0.3333 & 0.0000 & 0.7500 & 0.0936 \\
\hline Bsize & 3506 & 2.1674 & 2.1972 & 1.7918 & 2.7080 & 0.1875 \\
\hline CEOage & 3506 & 3.7941 & 3.8067 & 3.5264 & 4.0775 & 0.1468 \\
\hline CEOtenure & 3506 & 0.8025 & 0.8473 & 0.0000 & 1.5041 & 0.3982 \\
\hline CEOShare & 3506 & 0.0074 & 0.0000 & 0.0000 & 0.0759 & 0.0209 \\
\hline $\mathrm{CF}$ & 3506 & 0.1214 & 0.1048 & -0.6920 & 1.0010 & 0.3286 \\
\hline Sales t-1 & 3506 & 2.1735 & 1.3828 & 0.1743 & 9.9737 & 2.2189 \\
\hline Roa & 3506 & 0.0308 & 0.0346 & -0.1720 & 0.1462 & 0.0630 \\
\hline Size & 3506 & 21.0932 & 20.9937 & 19.5020 & 23.7757 & 0.9343 \\
\hline Market & 3506 & 8.0902 & 8.1400 & 0.0000 & 11.8000 & 2.3257 \\
\hline
\end{tabular}


Table 2

Correlation matrix. This table reports the correlation coefficients of the key variables used in our regression models. a and b correspond to significant level at the $1 \%$ and $5 \%$, respectively.

\begin{tabular}{|c|c|c|c|c|c|c|c|c|c|}
\hline & Investment & Debt $t-1$ & Sdebt $_{\mathrm{t}-1}$ & Ldebt $_{t-1}$ & $\mathrm{DM}_{\mathrm{t}-1}$ & Nature & $Q_{t-1}$ & Growth & Topshare \\
\hline Investment & 1 & & & & & & & & \\
\hline Debt $_{t-1}$ & $-0.054^{\mathrm{a}}$ & 1 & & & & & & & \\
\hline Sdebt $_{\mathrm{t}-1}$ & $-0.108^{a}$ & $0.820^{\mathrm{a}}$ & 1 & & & & & & \\
\hline Ldebt $_{t-1}$ & $0.066^{\mathrm{a}}$ & $0.544^{\mathrm{a}}$ & $-0.023^{\mathrm{b}}$ & 1 & & & & & \\
\hline $\mathrm{DM}_{\mathrm{t}-1}$ & $0.089^{\mathrm{a}}$ & $0.140^{\mathrm{a}}$ & $-0.382^{\mathrm{a}}$ & $0.778^{\mathrm{a}}$ & 1 & & & & \\
\hline Nature & 0.001 & 0.011 & $0.071^{\mathrm{a}}$ & $-0.086^{\mathrm{a}}$ & $-0.100^{\mathrm{a}}$ & 1 & & & \\
\hline$Q_{t-1}$ & $0.024^{\mathrm{b}}$ & $-0.204^{\mathrm{a}}$ & $-0.140^{\mathrm{a}}$ & $-0.160^{\mathrm{a}}$ & $-0.087^{\mathrm{a}}$ & $0.136^{\mathrm{a}}$ & 1 & & \\
\hline Growth & $0.210^{\mathrm{a}}$ & 0.008 & $-0.042^{\mathrm{a}}$ & $0.078^{a}$ & $0.077^{\mathrm{a}}$ & $0.038^{a}$ & $0.056^{\mathrm{a}}$ & 1 & \\
\hline Topshare & $0.107^{\mathrm{a}}$ & $-0.095^{\mathrm{a}}$ & $-0.131^{\mathrm{a}}$ & $0.027^{\mathrm{a}}$ & $0.082^{\mathrm{a}}$ & $-0.278^{\mathrm{a}}$ & $-0.181^{\mathrm{a}}$ & $0.068^{\mathrm{a}}$ & 1 \\
\hline Director & 0.014 & $-0.018^{\mathrm{b}}$ & 0.008 & $-0.046^{\mathrm{a}}$ & $-0.043^{\mathrm{a}}$ & $0.126^{\mathrm{a}}$ & $0.053^{\mathrm{a}}$ & $-0.016^{\mathrm{b}}$ & $-0.065^{\mathrm{a}}$ \\
\hline Indepen & $-0.035^{a}$ & 0.011 & -0.014 & $0.042^{\mathrm{a}}$ & $0.037^{\mathrm{a}}$ & $0.159^{a}$ & $-0.024^{\mathrm{b}}$ & $0.028^{a}$ & $-0.129^{a}$ \\
\hline Bsize & $0.063^{a}$ & $0.040^{\mathrm{a}}$ & -0.007 & $0.080^{\mathrm{a}}$ & $0.075^{\mathrm{a}}$ & $-0.180^{\mathrm{a}}$ & $-0.109^{a}$ & 0.005 & $0.030^{\mathrm{a}}$ \\
\hline CEOage & $-0.019^{\mathrm{b}}$ & -0.011 & $-0.051^{\mathrm{b}}$ & $0.054^{\mathrm{a}}$ & $0.063^{\mathrm{a}}$ & $-0.131^{\mathrm{a}}$ & $0.017^{\mathrm{b}}$ & $-0.045^{\mathrm{a}}$ & $0.043^{\mathrm{a}}$ \\
\hline CEOtenure & 0.009 & $-0.026^{\mathrm{a}}$ & $-0.035^{a}$ & 0.008 & $0.029^{a}$ & $-0.021^{b}$ & 0.005 & $-0.016^{\mathrm{b}}$ & 0.010 \\
\hline CEOShare & $0.113^{\mathrm{a}}$ & $-0.080^{\mathrm{a}}$ & $-0.046^{\mathrm{a}}$ & $-0.073^{\mathrm{a}}$ & $-0.067^{\mathrm{a}}$ & $0.260^{\mathrm{a}}$ & $0.080^{\mathrm{a}}$ & 0.004 & $-0.122^{a}$ \\
\hline $\mathrm{CF}$ & $0.124^{\mathrm{a}}$ & $-0.119^{a}$ & $-0.096^{\mathrm{a}}$ & $-0.071^{\mathrm{a}}$ & $-0.017^{\mathrm{b}}$ & $-0.016^{\mathrm{b}}$ & $0.059^{a}$ & $0.117^{\mathrm{a}}$ & $0.059^{\mathrm{a}}$ \\
\hline Sales $t-1$ & $0.113^{\mathrm{a}}$ & $-0.214^{\mathrm{a}}$ & $-0.129^{a}$ & $-0.186^{a}$ & $-0.102^{\mathrm{a}}$ & $0.031^{\mathrm{a}}$ & 0.009 & $0.119^{a}$ & $0.060^{\mathrm{a}}$ \\
\hline Roa & $0.207^{\mathrm{a}}$ & $-0.288^{\mathrm{a}}$ & $-0.323^{a}$ & $-0.028^{a}$ & $0.117^{a}$ & $0.023^{a}$ & $0.158^{\mathrm{a}}$ & $0.266^{\mathrm{a}}$ & $0.139^{\mathrm{a}}$ \\
\hline Size & $0.127^{\mathrm{a}}$ & $0.127^{a}$ & $-0.067^{\mathrm{a}}$ & $0.329^{a}$ & $0.328^{a}$ & $-0.192^{\mathrm{a}}$ & $-0.235^{\mathrm{a}}$ & $0.123^{a}$ & $0.198^{\mathrm{a}}$ \\
\hline Market & $-0.051^{\mathrm{a}}$ & $-0.076^{\mathrm{a}}$ & $-0.045^{\mathrm{a}}$ & $-0.069^{a}$ & $-0.046^{\mathrm{a}}$ & $0.173^{\mathrm{a}}$ & $0.069^{a}$ & $-0.017^{b}$ & $-0.100^{\mathrm{a}}$ \\
\hline
\end{tabular}

ratio of total bank loans to the book value of total assets ${ }^{13}$; Sdebt $_{i, t-1}$ is the short-term loan ratio, defined as the lagged ratio of short-term loans to the book value of total assets; Ldebt $_{i, t-1}$ is the long-term loan ratio, defined as the lagged ratio of long-term loans to the book value of total assets; $\mathrm{Q}_{\mathrm{i}, \mathrm{t}-1}$ is the lagged Tobin's $\mathrm{Q}$; and Growth is the average sales growth rate between $t$ and t-1. Both Tobin's Q and Growth are proxies for firms' future growth opportunities. Following previous studies (Bai et al., 2004; Firth et al., 2008), Tobin's Q is calculated as the market value of common stock plus the book value of debt divided by the book value of total assets. The book value per share is used as a proxy for the market value of non-tradable shares.

For two reasons, we notice that Tobin's Q might not be a perfect proxy for Chinese firms' future growth. First of all, publicly listed firms in China usually hold a large amount of non-tradable shares, ${ }^{14}$ which may lead to an inaccurate estimation of Tobin's Q. Secondly, China's stock market is only at its primary stage. Stock price fluctuations "tend to reflect market-level information rather than firms' fundamental information" (Firth et al., 2008). Morck et al. (2000) point out that more than $80 \%$ of the stocks listed on the Chinese exchanges move in the same direction in a given week. This fact suggests that the stock market risk dominates the individual stock risk in China's stock market. Therefore, stock returns may not be a good proxy for the performance of Chinese publicly listed firms. Apart from the above two reasons, there are many "black transactions" in the Chinese stock exchanges without being monitored by the Chinese SEC. To alleviate these concerns, we also use firms' historical sales growth as the alternative proxy for future growth.

For consistency, we follow prior studies by adding control variables to proxy for financial constraints in Regression 1: firms' cash flow, sales, profitability, and size conditions. $\mathrm{CF}_{\mathrm{i}, \mathrm{t}}$ is defined as the ratio of the operating cash flow of firm $\mathrm{i}$ at time to the lagged fixed assets; Sales $s_{i, t-1}$ is defined as the ratio of sales of firm i at time t-1 to the lagged fixed assets; Roa $a_{i, t}$ is defined as the ratio of net profits of firm $i$ at time $t$ to the book value of total assets; and Size $_{i, t}$ is defined as firm i's natural logarithm of total assets. To control for the effect of the CEO's trait and corporate governance on investment (Dong \& Gou, 2010), we also include the CEO's characteristics variables, such as age, tenure, and CEO shareholdings, and governance variables, such as the shareholdings of the largest shareholder, CEO duality dummy, board independence, board size, and regional marketization level ${ }^{15}$ in Regression 1. According to the industrial classification of the Chinese Security Regulatory Commission (CSRC), all firms in our sample are classified into 12 industries. Because most of the sample firms are classified into the manufacturing industry, the firms in the manufacturing sector are further classified into 10 sub-industries based on their 2-digit code. In the end, all the sample firms are classified into 21 industries.

\footnotetext{
${ }^{13}$ Lang et al. (1996) discuss the reasons for the use of book values. Consistent with Lang et al. (1996), Aivazian et al. (2005), and Firth et al. (2008), we also choose book values to calculate the bank loan ratio.

${ }^{14}$ In late 2005, China started a share reform program. As the reform has been completed, all of the non-tradable shares of listed firms will become tradable on the public market.

15 The regional marketization index is compiled by the National Economic Research Institute of China (Fan \& Wang, 2012). It is a comprehensive index that captures the regional market development of the following aspects: relationship between government and markets, development of non-state-owned sector in the economy, development of product markets, development of factor markets, and development of market intermediaries and legal environment. High scores of the index suggest good institutional development. This index has also been used in Wang et al. (2008) and Li et al. (2009).
} 


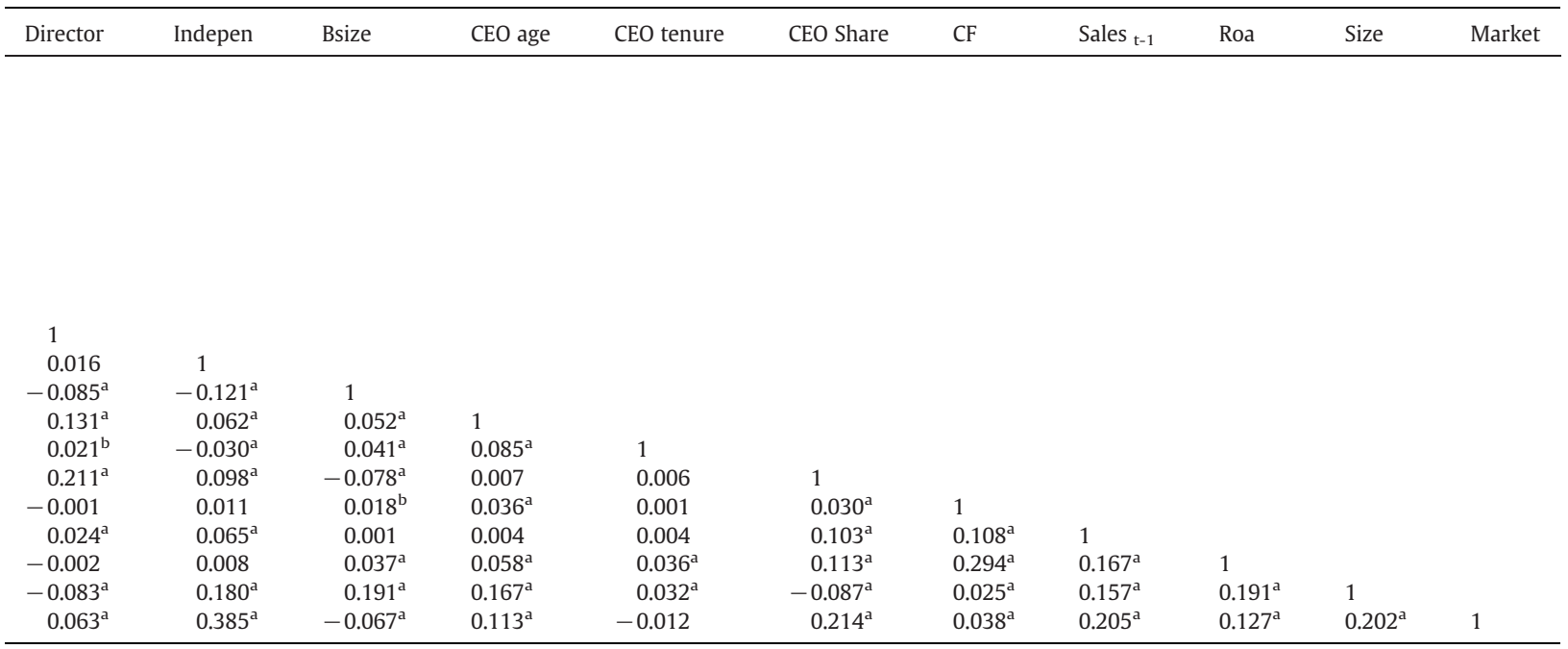

Although both the underinvestment theory and the overinvestment theory predict a negative relation between firms' leverage and their investment, these two theories have different implications for high growth versus low growth firms. In the underinvestment theory, the negative relation between firms' leverage and their investment should be stronger for high growth firms than for low growth firms due to the debt overhang problem (Myers, 1977). While the overinvestment theory suggests that the negative relation between firms' leverage and their investment should be stronger for low-growth firms than for high-growth firms because of the debt's governance effect on firm managers (Jensen, 1986; Stulz, 1990). To differentiate the roles of leverage in high-growth versus low-growth firms, we develop our empirical tests by following the studies of Aivazian et al. (2005), Ahn et al. (2006), and Firth et al. (2008). The following regressions are tested:

$$
\begin{aligned}
\text { Investment }_{\mathrm{i}, \mathrm{t}}= & \beta_{0}+\beta_{1} \text { Debt }_{\mathrm{i}, \mathrm{t}-1}\left(\text { or Sdebt }_{\mathrm{i}, \mathrm{t}-1}, \text { Ldebt }_{\mathrm{i}, \mathrm{t}-1}\right)+\beta_{2} \mathrm{Q}_{\mathrm{i}, \mathrm{t}-1}\left(\text { or Growth }_{\mathrm{i}, \mathrm{t}}\right) \\
& +\beta_{3} \text { Debt }_{\mathrm{i}, \mathrm{t}-\mathrm{1}}\left(\text { or Sdebt }_{\mathrm{i}, \mathrm{t}-\mathrm{1}} \text { Ldebt }_{\mathrm{i}, \mathrm{t}-\mathrm{1}}\right) \times \mathrm{DQ}_{\mathrm{i}, \mathrm{t}-1}\left(\text { orDG }_{\mathrm{i}, \mathrm{t}}\right)+\beta_{4} \text { Topshare }_{\mathrm{i}, \mathrm{t}} \\
& +\beta_{5} \text { Director }_{\mathrm{i}, \mathrm{t}}+\beta_{6} \text { Indepen }_{\mathrm{i}, \mathrm{t}}+\beta_{7} \text { Bsize }_{\mathrm{i}, \mathrm{t}}+\beta_{8} \text { CEOage }_{\mathrm{i}, \mathrm{t}}+\beta_{9} \text { CEOtenure }_{\mathrm{i}, \mathrm{t}} \\
& +\beta_{10} \text { CEOshare }_{\mathrm{i}, \mathrm{t}}+\beta_{11} \text { CF }_{\mathrm{i}, \mathrm{t}}+\beta_{12} \text { Sales }_{\mathrm{i}, \mathrm{t}-1}+\beta_{13} \text { Roa }_{\mathrm{i}, \mathrm{t}}+\beta_{14} \text { Size }_{\mathrm{i}, \mathrm{t}}+\beta_{15} \text { Market }_{\mathrm{i}, \mathrm{t}}+\varepsilon_{\mathrm{i}, \mathrm{t}}
\end{aligned}
$$

In Regression 2, $\mathrm{DQ}_{\mathrm{i}, \mathrm{t}-1}$ and $\mathrm{DG}_{\mathrm{i}, \mathrm{t}}$ are dummy variables. $\mathrm{DQ}_{\mathrm{i}, \mathrm{t}-1}$ is equal to 1 if $\mathrm{Q}_{\mathrm{i}, \mathrm{t}-1}$ is greater than the median value of $\mathrm{Q}_{\mathrm{i}, \mathrm{t}-1}$ in the whole sample and 0 otherwise, and $D G_{i, t}$ is equal to 1 if Growth $\mathrm{h}_{\mathrm{i}, \mathrm{t}}$ is greater than the median value of Growth $\mathrm{h}_{\mathrm{i}, \mathrm{t}}$ in the whole sample and 0 otherwise.

To compare the disciplining roles of short-term and long-term loans, we test the following regressions:

$$
\begin{aligned}
\text { Investment }_{\mathrm{i}, \mathrm{t}}= & \beta_{0}+\beta_{1} \text { Debt }_{\mathrm{i}, \mathrm{-}-1}+\beta_{2} \text { Debt }_{\mathrm{i}, \mathrm{-}-1} \times \text { DM }_{\mathrm{i}, \mathrm{t}-1}+\beta_{3} \text { DM }_{\mathrm{i}, \mathrm{t}-1}+\beta_{4} \mathrm{Q}_{\mathrm{i}, \mathrm{t}-\mathrm{1}}\left(\text { or Growth }_{\mathrm{i}, \mathrm{t}}\right) \\
& +\beta_{5} \text { Topshare }_{\mathrm{i}, \mathrm{t}}+\beta_{6} \text { Director }_{\mathrm{i}, \mathrm{t}}+\beta_{7} \text { Indepen }_{\mathrm{i}, \mathrm{t}}+\beta_{8} \text { Bsize }_{\mathrm{i}, \mathrm{t}}+\beta_{9} \text { CEOage }_{\mathrm{i}, \mathrm{t}} \\
& +\beta_{10} \text { CEOtenure }_{\mathrm{i}, \mathrm{t}}+\beta_{11} \text { CEOshare }_{\mathrm{i}, \mathrm{t}}+\beta_{12} \mathrm{CF}_{\mathrm{i}, \mathrm{t}}+\beta_{13} \text { Sales }_{\mathrm{i}, \mathrm{t}-1}+\beta_{14} \text { Roa }_{\mathrm{i}, \mathrm{t}} \\
& +\beta_{15} \text { Size }_{\mathrm{i}, \mathrm{t}}+\beta_{16} \text { Market }_{\mathrm{i}, \mathrm{t}}+\varepsilon_{\mathrm{i}, \mathrm{t}}
\end{aligned}
$$

In Regression 3, $\mathrm{DM}_{\mathrm{i}, \mathrm{t}-1}$ is defined as the lagged ratio of long-term loans to total bank loans.

\section{Empirical results}

\subsection{Main regression analysis}

Table 3 reports the regression results using Tobin's $Q$ as the proxy for firms' future growth opportunities. The model specifications are given in Regression 1 and Regression 2. Panel A of Table 3 presents the results when the independent variable is the total bank loan ratios. All seven regressions show that the coefficients of the total bank loan ratios are negative and most are significant at the $1 \%$ level, the exceptions being Columns (3) and (4). This finding is consistent with the prior studies (Ahn et al., 
Table 3

Regression analysis using Tobin's Q as the proxy for firms' future growth opportunities.

\begin{tabular}{|c|c|c|c|c|c|c|c|}
\hline & \multicolumn{3}{|l|}{ Total sample } & \multicolumn{2}{|l|}{ SOEs } & \multicolumn{2}{|l|}{ Non-SOEs } \\
\hline & $(1)$ & (2) & (3) & $(4)$ & (5) & (6) & $(7)$ \\
\hline \multicolumn{8}{|c|}{$\begin{array}{l}\text { Panel A. Total bank loans. Panel A reports the effect of total bank loans on investment using Tobin's Q as the proxy for firms' future growth opportunities. The } \\
\text { model specifications are given in Regression } 1 \text { and Regression } 2 \text {. The independent variable is the total bank loan ratio. The sample includes all the } \\
\text { observations in our refined data set and the sample period is from } 2000 \text { to } 2011 \text {. t-statistics are in parentheses. *, **, }{ }^{* * *} \text { denote significance levels of } 10 \%, 5 \% \text {, } \\
\text { and } 1 \% \text {, respectively, two-tailed. }\end{array}$} \\
\hline Intercept & $-0.752^{* * *}$ & $-0.813^{* * *}$ & $-0.803^{* * *}$ & $-0.780^{* * *}$ & $-0.844^{* * *}$ & $-0.826^{\text {*** }}$ & $-0.892^{* * *}$ \\
\hline & $(-9.63)$ & $(-10.37)$ & $(-10.01)$ & $(-7.90)$ & $(-8.52)$ & $(-5.84)$ & $(-6.30)$ \\
\hline Debt $_{t-1}$ & $\begin{array}{l}-0.038^{* * *} \\
(-2.60)\end{array}$ & $\begin{array}{l}-0.094^{* * *} \\
(-5.63)\end{array}$ & $\begin{array}{l}-0.015 \\
(-0.84)\end{array}$ & $\begin{array}{l}-0.014 \\
(-0.79)\end{array}$ & $\begin{array}{l}-0.063^{* * *} \\
(-3.15)\end{array}$ & $\begin{array}{l}-0.091^{\text {*** }} \\
(-3.54)\end{array}$ & $\begin{array}{l}-0.174^{* * *} \\
(-5.59)\end{array}$ \\
\hline $\operatorname{Debt}_{t-1} \times \mathrm{DQ}_{\mathrm{t}-1}$ & & $\begin{array}{l}0.112^{* * *} \\
(6.85)\end{array}$ & & & $\begin{array}{l}0.111^{* * *} \\
(5.42)\end{array}$ & & $\begin{array}{l}0.134^{* * *} \\
(4.70)\end{array}$ \\
\hline Debt $_{\mathrm{t}-1} \times$ Nature & & & $\begin{array}{l}-0.076^{* * *} \\
(-2.74)\end{array}$ & & & & \\
\hline Nature & & & $\begin{array}{l}0.030^{* * *} \\
(3.61)\end{array}$ & & & & \\
\hline$Q_{t-1}$ & $\begin{array}{l}0.029^{* * *} \\
(7.96)\end{array}$ & $\begin{array}{l}0.019^{* * *} \\
(4.87)\end{array}$ & $\begin{array}{l}0.029^{* * *} \\
(7.86)\end{array}$ & $\begin{array}{l}0.035^{* * *} \\
(7.21)\end{array}$ & $\begin{array}{l}0.024^{* * *} \\
(4.60)\end{array}$ & $\begin{array}{l}0.023^{* * *} \\
(3.94)\end{array}$ & $\begin{array}{l}0.013^{* *} \\
(2.01)\end{array}$ \\
\hline Topshare & $\begin{array}{l}-0.003 \\
(-0.22)\end{array}$ & $\begin{array}{l}-0.002 \\
(-0.12)\end{array}$ & $\begin{array}{l}0.004 \\
(0.30)\end{array}$ & $\begin{array}{l}-0.026 \\
(-1.52)\end{array}$ & $\begin{array}{l}-0.025 \\
(-1.48)\end{array}$ & $\begin{array}{l}0.081^{* * *} \\
(2.90)\end{array}$ & $\begin{array}{l}0.083^{* * *} \\
(2.99)\end{array}$ \\
\hline Director & $\begin{array}{l}0.009 \\
(1.41)\end{array}$ & $\begin{array}{l}0.008 \\
(1.26)\end{array}$ & $\begin{array}{l}0.008 \\
(1.24)\end{array}$ & $\begin{array}{l}0.001 \\
(0.11)\end{array}$ & $\begin{array}{l}0.000 \\
(0.01)\end{array}$ & $\begin{array}{l}0.012 \\
(1.25)\end{array}$ & $\begin{array}{l}0.011 \\
(1.08)\end{array}$ \\
\hline Indepen & $\begin{array}{l}0.019 \\
(0.51)\end{array}$ & $\begin{array}{l}0.018 \\
(0.49)\end{array}$ & $\begin{array}{l}0.017 \\
(0.46)\end{array}$ & $\begin{array}{l}0.002 \\
(0.04)\end{array}$ & $\begin{array}{l}-0.002 \\
(-0.05)\end{array}$ & $\begin{array}{l}0.039 \\
(0.58)\end{array}$ & $\begin{array}{l}0.046 \\
(0.68)\end{array}$ \\
\hline Bsize & $\begin{array}{l}0.013 \\
(1.24)\end{array}$ & $\begin{array}{l}0.013 \\
(1.17)\end{array}$ & $\begin{array}{l}0.016 \\
(1.50)\end{array}$ & $\begin{array}{l}0.008 \\
(0.66)\end{array}$ & $\begin{array}{l}0.009 \\
(0.68)\end{array}$ & $\begin{array}{l}0.023 \\
(1.09)\end{array}$ & $\begin{array}{l}0.019 \\
(0.90)\end{array}$ \\
\hline CEOage & $\begin{array}{l}-0.065^{* * *} \\
(-4.35)\end{array}$ & $\begin{array}{l}-0.061^{* * *} \\
(-4.09)\end{array}$ & $\begin{array}{l}-0.059^{* * *} \\
(-3.90)\end{array}$ & $\begin{array}{l}-0.072^{* * *} \\
(-3.75)\end{array}$ & $\begin{array}{l}-0.066^{* * *} \\
(-3.44)\end{array}$ & $\begin{array}{l}-0.032 \\
(-1.24)\end{array}$ & $\begin{array}{l}-0.030 \\
(-1.19)\end{array}$ \\
\hline CEOtenure & $\begin{array}{l}0.000 \\
(0.06)\end{array}$ & $\begin{array}{l}-0.000 \\
(-0.02)\end{array}$ & $\begin{array}{l}0.000 \\
(0.06)\end{array}$ & $\begin{array}{l}-0.004 \\
(-0.72)\end{array}$ & $\begin{array}{l}-0.005 \\
(-0.79)\end{array}$ & $\begin{array}{l}0.009 \\
(1.05)\end{array}$ & $\begin{array}{l}0.008 \\
(0.98)\end{array}$ \\
\hline CEOShare & $\begin{array}{l}1.362^{* * *} \\
(7.25)\end{array}$ & $\begin{array}{l}1.407^{* * *} \\
(7.50)\end{array}$ & $\begin{array}{l}1.253^{* * *} \\
(6.58)\end{array}$ & $\begin{array}{l}1.968^{* * *} \\
(2.64)\end{array}$ & $\begin{array}{l}2.121^{* * *} \\
(2.85)\end{array}$ & $\begin{array}{l}1.151^{* * *} \\
(5.37)\end{array}$ & $\begin{array}{l}1.182^{* * *} \\
(5.53)\end{array}$ \\
\hline $\mathrm{CF}$ & $\begin{array}{l}0.061^{* * *} \\
(8.05)\end{array}$ & $\begin{array}{l}0.063^{* * *} \\
(8.25)\end{array}$ & $\begin{array}{l}0.061^{\text {*** }} \\
(8.07)\end{array}$ & $\begin{array}{l}0.065^{* * *} \\
(6.49)\end{array}$ & $\begin{array}{l}0.066^{* * *} \\
(6.62)\end{array}$ & $\begin{array}{l}0.057^{* * *} \\
(4.81)\end{array}$ & $\begin{array}{l}0.059^{* * *} \\
(4.98)\end{array}$ \\
\hline Sales $t-1$ & $\begin{array}{l}0.011^{* * *} \\
(10.01)\end{array}$ & $\begin{array}{l}0.010^{* * *} \\
(9.87)\end{array}$ & $\begin{array}{l}0.011^{\text {*** }} \\
(9.95)\end{array}$ & $\begin{array}{l}0.009^{* * *} \\
(6.75)\end{array}$ & $\begin{array}{l}0.009^{* * *} \\
(6.64)\end{array}$ & $\begin{array}{l}0.013^{* * *} \\
(7.04)\end{array}$ & $\begin{array}{l}0.012^{* * *} \\
(6.91)\end{array}$ \\
\hline Roa & $\begin{array}{l}0.381^{\text {*** }} \\
(9.48)\end{array}$ & $\begin{array}{l}0.364^{* * *} \\
(9.04)\end{array}$ & $\begin{array}{l}0.377^{* * *} \\
(9.34)\end{array}$ & $\begin{array}{l}0.415^{* * *} \\
(8.07)\end{array}$ & $\begin{array}{l}0.401^{\text {*** }} \\
(7.78)\end{array}$ & $\begin{array}{l}0.290^{* * * *} \\
(4.39)\end{array}$ & $\begin{array}{l}0.266^{* * *} \\
(4.03)\end{array}$ \\
\hline Size & $\begin{array}{l}0.049^{* * *} \\
(18.82)\end{array}$ & $\begin{array}{l}0.053^{* * *} \\
(19.80)\end{array}$ & $\begin{array}{l}0.050^{* * *} \\
(18.93)\end{array}$ & $\begin{array}{l}0.053^{* * *} \\
(16.26)\end{array}$ & $\begin{array}{l}0.0568^{* * *} \\
(16.98)\end{array}$ & $\begin{array}{l}0.046^{* * *} \\
(9.83)\end{array}$ & $\begin{array}{l}0.050^{* * *} \\
(10.60)\end{array}$ \\
\hline Market & $\begin{array}{l}-0.009^{* * *} \\
(-7.97)\end{array}$ & $\begin{array}{l}-0.009^{* * *} \\
(-7.94)\end{array}$ & $\begin{array}{l}-0.009^{* * *} \\
(-8.09)\end{array}$ & $\begin{array}{l}-0.011^{* * *} \\
(-7.72)\end{array}$ & $\begin{array}{l}-0.011^{* * *} \\
(-7.75)\end{array}$ & $\begin{array}{l}-0.006^{\text {*** }} \\
(-3.26)\end{array}$ & $\begin{array}{l}-0.006^{* * *} \\
(-3.12)\end{array}$ \\
\hline Industry dummy & Included & Included & Included & Included & Included & Included & Included \\
\hline Year dummy & Included & Included & Included & Included & Included & Included & Included \\
\hline Adjusted $\mathrm{R}^{2}$ & 0.1274 & 0.1312 & 0.1283 & 0.1274 & 0.1310 & 0.1333 & 0.1386 \\
\hline Observations & 10,451 & 10,451 & 10,451 & 6945 & 6945 & 3506 & 3506 \\
\hline
\end{tabular}

Panel B. Short-term loans. Panel B reports the effect of short-term loans on investment using Tobin's Q as the proxy for firms' future growth opportunities. The model specifications are given in Regression 1 and Regression 2 . The independent variable is the short-term loan ratio. The sample includes all the observations in our refined data set and the sample period is from 2000 to 2011. t-statistics are in parentheses. *, **, *** denote significance levels of $10 \%, 5 \%$, and $1 \%$, respectively, two-tailed.

\begin{tabular}{|c|c|c|c|c|c|c|c|}
\hline Intercept & $-0.725^{* * *}$ & $-0.771^{* * *}$ & $-0.777^{* * *}$ & $-0.763^{* * *}$ & & & $-0.835^{* * *}$ \\
\hline Sdebt $_{\mathrm{t}-1}$ & $\begin{array}{l}(-9.29) \\
-0.081^{\text {*** }} \\
(-4.78)\end{array}$ & $\begin{array}{l}(-9.85) \\
-0.150^{* * *} \\
(-7.43)\end{array}$ & $\begin{array}{l}(-9.70) \\
-0.063^{* * *} \\
(-3.05)\end{array}$ & $\begin{array}{l}(-7.75) \\
-0.061^{* * *} \\
(-2.88)\end{array}$ & $\begin{array}{l}(-8.24) \\
-0.126^{* * *} \\
(-5.16)\end{array}$ & $\begin{array}{l}(-5.58) \\
-0.124^{\text {*** }} \\
(-4.22)\end{array}$ & $\begin{array}{l}(-5.92) \\
-0.205^{* * *} \\
(-5.65)\end{array}$ \\
\hline Sdebt $_{\mathrm{t}-1} \times \mathrm{DQ}_{\mathrm{t}-1}$ & & $\begin{array}{l}0.130^{* * *} \\
(6.30)\end{array}$ & & & $\begin{array}{l}0.137^{* * *} \\
(5.25)\end{array}$ & & $\begin{array}{l}0.132^{* * *} \\
(3.80)\end{array}$ \\
\hline Sdebt $_{\mathrm{t}-1} \times$ Nature & & & $\begin{array}{l}-0.058^{*} \\
(-1.78)\end{array}$ & & & & \\
\hline Nature & & & $\begin{array}{l}0.023^{\text {*** }} \\
(2.94)\end{array}$ & & & & \\
\hline$Q_{t-1}$ & $\begin{array}{l}0.029^{* * *} \\
(7.95)\end{array}$ & $\begin{array}{l}0.020^{* * *} \\
(5.20)\end{array}$ & $\begin{array}{l}0.029^{* * *} \\
(7.86)\end{array}$ & $\begin{array}{l}0.035^{* * *} \\
(7.18)\end{array}$ & $\begin{array}{l}0.024^{* * *} \\
(4.73)\end{array}$ & $\begin{array}{l}0.024^{* * *} \\
(3.99)\end{array}$ & $\begin{array}{l}0.016^{* *} \\
(2.48)\end{array}$ \\
\hline Topshare & $\begin{array}{l}-0.006 \\
(-0.45)\end{array}$ & $\begin{array}{l}-0.006 \\
(-0.41)\end{array}$ & $\begin{array}{l}0.001 \\
(0.08)\end{array}$ & $\begin{array}{l}-0.029^{*} \\
(-1.75)\end{array}$ & $\begin{array}{l}-0.029^{*} \\
(-1.72)\end{array}$ & $\begin{array}{l}0.080^{* * *} \\
(2.86)\end{array}$ & $\begin{array}{l}0.080^{* * *} \\
(2.89)\end{array}$ \\
\hline Director & $\begin{array}{l}0.009 \\
(1.43)\end{array}$ & $\begin{array}{l}0.008 \\
(1.33)\end{array}$ & $\begin{array}{l}0.008 \\
(1.25)\end{array}$ & $\begin{array}{l}0.001 \\
(0.16)\end{array}$ & $\begin{array}{l}0.001 \\
(0.09)\end{array}$ & $\begin{array}{l}0.012 \\
(1.21)\end{array}$ & $\begin{array}{l}0.011 \\
(1.09)\end{array}$ \\
\hline Indepen & $\begin{array}{l}0.018 \\
(0.49)\end{array}$ & $\begin{array}{l}0.017 \\
(0.46)\end{array}$ & $\begin{array}{l}0.016 \\
(0.45)\end{array}$ & $\begin{array}{l}0.002 \\
(0.03)\end{array}$ & $\begin{array}{l}-0.004 \\
(-0.09)\end{array}$ & $\begin{array}{l}0.040 \\
(0.59)\end{array}$ & $\begin{array}{l}0.045 \\
(0.66)\end{array}$ \\
\hline
\end{tabular}


Table 3 (continued)

Total sample

(1)

(2)

(3)

SOES

(4)

(5)

Panel B. Short-term loans. Panel B reports the effect of short-term loans on investment using Tobin's $Q$ as the proxy for firms' future growth opportunities. The model specifications are given in Regression 1 and Regression 2. The independent variable is the short-term loan ratio. The sample includes all the observations in our refined data set and the sample period is from 2000 to 2011. t-statistics are in parentheses. ${ }^{*},{ }^{* *},{ }^{* * *}$ denote significance levels of $10 \%, 5 \%$, and $1 \%$, respectively, two-tailed.

\begin{tabular}{|c|c|c|c|c|c|c|c|}
\hline Bsize & $\begin{array}{l}0.013 \\
(1.20)\end{array}$ & $\begin{array}{l}0.012 \\
(1.12)\end{array}$ & $\begin{array}{l}0.016 \\
(1.49)\end{array}$ & $\begin{array}{l}0.008 \\
(0.63)\end{array}$ & $\begin{array}{l}0.008 \\
(0.67)\end{array}$ & $\begin{array}{l}0.023 \\
(1.07)\end{array}$ & $\begin{array}{l}0.019 \\
(0.90)\end{array}$ \\
\hline CEOage & $\begin{array}{l}-0.066^{* * *} \\
(-4.39)\end{array}$ & $\begin{array}{l}-0.062^{* * *} \\
(-4.16)\end{array}$ & $\begin{array}{l}-0.060^{* * *} \\
(-3.95)\end{array}$ & $\begin{array}{l}-0.072^{* * *} \\
(-3.79)\end{array}$ & $\begin{array}{l}-0.067^{* * *} \\
(-3.52)\end{array}$ & $\begin{array}{l}-0.031 \\
(-1.22)\end{array}$ & $\begin{array}{l}-0.029 \\
(-1.15)\end{array}$ \\
\hline CEOtenure & $\begin{array}{l}-0.000 \\
(-0.01)\end{array}$ & $\begin{array}{l}-0.000 \\
(-0.09)\end{array}$ & $\begin{array}{l}-0.000 \\
(-0.02)\end{array}$ & $\begin{array}{l}-0.005 \\
(-0.76)\end{array}$ & $\begin{array}{l}-0.005 \\
(-0.85)\end{array}$ & $\begin{array}{l}0.009 \\
(0.99)\end{array}$ & $\begin{array}{l}0.009 \\
(0.96)\end{array}$ \\
\hline CEOShare & $\begin{array}{l}1.352^{\text {**** }} \\
(7.20)\end{array}$ & $\begin{array}{l}1.384^{* * *} \\
(7.38)\end{array}$ & $\begin{array}{l}1.265^{* * *} \\
(6.66)\end{array}$ & $\begin{array}{l}1.900^{* *} \\
(2.55)\end{array}$ & $\begin{array}{l}2.026^{* * *} \\
(2.72)\end{array}$ & $\begin{array}{l}1.152^{\text {*** }} \\
(5.38)\end{array}$ & $\begin{array}{l}1.174^{* * *} \\
(5.49)\end{array}$ \\
\hline $\mathrm{CF}$ & $\begin{array}{l}0.061^{* * *} \\
(8.10)\end{array}$ & $\begin{array}{l}0.063^{\text {*** }} \\
(8.28)\end{array}$ & $\begin{array}{l}0.062^{* * *} \\
(8.14)\end{array}$ & $\begin{array}{l}0.065^{* * *} \\
(6.53)\end{array}$ & $\begin{array}{l}0.066^{* * *} \\
(6.64)\end{array}$ & $\begin{array}{l}0.058^{* * *} \\
(4.86)\end{array}$ & $\begin{array}{l}0.060^{* * *} \\
(5.03)\end{array}$ \\
\hline Sales ${ }_{t-1}$ & $\begin{array}{l}0.011^{* * *} \\
(10.17)\end{array}$ & $\begin{array}{l}0.011^{\text {*** }} \\
(10.13)\end{array}$ & $\begin{array}{l}0.011^{\text {*** }} \\
(10.09)\end{array}$ & $\begin{array}{l}0.009^{* * *} \\
(6.78)\end{array}$ & $\begin{array}{l}0.009^{* * * *} \\
(6.78)\end{array}$ & $\begin{array}{l}0.013^{* * *} \\
(7.27)\end{array}$ & $\begin{array}{l}0.013^{* * *} \\
(7.16)\end{array}$ \\
\hline Roa & $\begin{array}{l}0.357^{* * *} \\
(8.84)\end{array}$ & $\begin{array}{l}0.344^{* * *} \\
(8.52)\end{array}$ & $\begin{array}{l}0.350^{* * *} \\
(8.65)\end{array}$ & $\begin{array}{l}0.384^{* * *} \\
(7.43)\end{array}$ & $\begin{array}{l}0.373^{\text {*** }} \\
(7.23)\end{array}$ & $\begin{array}{l}0.273^{* * *} \\
(4.12)\end{array}$ & $\begin{array}{l}0.258^{\text {*** }} \\
(3.88)\end{array}$ \\
\hline Size & $\begin{array}{l}0.048^{\text {*** }} \\
(18.83)\end{array}$ & $\begin{array}{l}0.051^{* * *} \\
(19.63)\end{array}$ & $\begin{array}{l}0.049^{\text {*** }} \\
(19.01)\end{array}$ & $\begin{array}{l}0.053^{\text {**** }} \\
(16.54)\end{array}$ & $\begin{array}{l}0.055^{\text {*** }} \\
(17.18)\end{array}$ & $\begin{array}{l}0.044^{* * *} \\
(9.57)\end{array}$ & $\begin{array}{l}0.047^{* * *} \\
(10.12)\end{array}$ \\
\hline Market & $\begin{array}{l}-0.009^{* * *} \\
(-7.67)\end{array}$ & $\begin{array}{l}-0.008^{* * *} \\
(-7.61)\end{array}$ & $\begin{array}{l}-0.009^{* * *} \\
(-7.82)\end{array}$ & $\begin{array}{l}-0.011^{* * *} \\
(-7.54)\end{array}$ & $\begin{array}{l}-0.011^{* * *} \\
(-7.55)\end{array}$ & $\begin{array}{l}-0.006^{* * *} \\
(-3.08)\end{array}$ & $\begin{array}{l}-0.006^{* * *} \\
(-2.96)\end{array}$ \\
\hline Industry dummy & Included & Included & Included & Included & Included & Included & Included \\
\hline Year dummy & Included & Included & Included & Included & Included & Included & Included \\
\hline Adjusted $\mathrm{R}^{2}$ & 0.1287 & 0.1320 & 0.1294 & 0.1284 & 0.1317 & 0.1346 & 0.1380 \\
\hline Observations & 10,451 & 10,451 & 10,451 & 6945 & 6945 & 3506 & 3506 \\
\hline
\end{tabular}

Panel C. Long-term loans. Panel C reports the effect of long-term loans on investment using Tobin's Q as the proxy for firms' future growth opportunities. The model specifications are given in Regression 1 and Regression 2 . The independent variable is the long-term loan ratio. The sample includes all the observations in our refined data set and the sample period is from 2000 to 2011 . t-statistics are in parentheses. ${ }^{*}, * *, * * *$ denote significance levels of $10 \%, 5 \%$, and $1 \%$, respectively, two-tailed.

\begin{tabular}{|c|c|c|c|c|c|c|c|}
\hline Intercept & $\begin{array}{l}-0.705^{\text {*** }} \\
(-8.92)\end{array}$ & $\begin{array}{l}-0.737^{* * *} \\
(-9.32)\end{array}$ & $\begin{array}{l}-0.745^{* * *} \\
(-9.20)\end{array}$ & $\begin{array}{l}-0.728^{* * *} \\
(-7.31)\end{array}$ & $\begin{array}{l}-0.760^{* * *} \\
(-7.62)\end{array}$ & $\begin{array}{l}-0.771^{\text {*** }} \\
(-5.39)\end{array}$ & $\begin{array}{l}-0.800^{* * *} \\
(-5.59)\end{array}$ \\
\hline Ldebt $_{\mathrm{t}-1}$ & $\begin{array}{l}0.084^{\text {*** }} \\
(3.03)\end{array}$ & $\begin{array}{l}-0.014 \\
(-0.42)\end{array}$ & $\begin{array}{l}0.108^{* * *} \\
(3.40)\end{array}$ & $\begin{array}{l}0.099^{* * *} \\
(3.02)\end{array}$ & $\begin{array}{l}0.028 \\
(0.75)\end{array}$ & $\begin{array}{l}0.033 \\
(0.63)\end{array}$ & $\begin{array}{l}-0.173^{* *} \\
(-2.50)\end{array}$ \\
\hline Ldebt $_{\mathrm{t}-1} \times \mathrm{DQ}_{\mathrm{t}-1}$ & & $\begin{array}{l}0.258^{* * *} \\
(5.82)\end{array}$ & & & $\begin{array}{l}0.228^{* * *} \\
(4.26)\end{array}$ & & $\begin{array}{l}0.383^{* * *} \\
(4.52)\end{array}$ \\
\hline Ldebt $_{\mathrm{t}-1} \times$ Nature & & & $\begin{array}{l}-0.084 \\
(-1.56)\end{array}$ & & & & \\
\hline Nature & & & $\begin{array}{l}0.015^{* * *} \\
(2.72)\end{array}$ & & & & \\
\hline $\mathrm{Q}_{\mathrm{t}-1}$ & $\begin{array}{l}0.031^{\text {*** }} \\
(8.42)\end{array}$ & $\begin{array}{l}0.026^{* * *} \\
(6.86)\end{array}$ & $\begin{array}{l}0.031^{* * *} \\
(8.40)\end{array}$ & $\begin{array}{l}0.036^{\text {*** }} \\
(7.53)\end{array}$ & $\begin{array}{l}0.031^{\text {*** }} \\
(6.33)\end{array}$ & $\begin{array}{l}0.025^{\text {*** }} \\
(4.31)\end{array}$ & $\begin{array}{l}0.019^{* * *} \\
(3.12)\end{array}$ \\
\hline Topshare & $\begin{array}{l}0.004 \\
(0.29)\end{array}$ & $\begin{array}{l}0.006 \\
(0.46)\end{array}$ & $\begin{array}{l}0.011 \\
(0.76)\end{array}$ & $\begin{array}{l}-0.020 \\
(-1.19)\end{array}$ & $\begin{array}{l}-0.019 \\
(-1.11)\end{array}$ & $\begin{array}{l}0.087^{* * *} \\
(3.13)\end{array}$ & $\begin{array}{l}0.091^{* * *} \\
(3.29)\end{array}$ \\
\hline Director & $\begin{array}{l}0.009 \\
(1.38)\end{array}$ & $\begin{array}{l}0.008 \\
(1.24)\end{array}$ & $\begin{array}{l}0.008 \\
(1.28)\end{array}$ & $\begin{array}{l}0.001 \\
(0.13)\end{array}$ & $\begin{array}{l}0.001 \\
(0.07)\end{array}$ & $\begin{array}{l}0.012 \\
(1.25)\end{array}$ & $\begin{array}{l}0.011 \\
(1.10)\end{array}$ \\
\hline Indepen & $\begin{array}{l}0.015 \\
(0.42)\end{array}$ & $\begin{array}{l}0.015 \\
(0.41)\end{array}$ & $\begin{array}{l}0.013 \\
(0.36)\end{array}$ & $\begin{array}{l}-0.00141 \\
(-0.03)\end{array}$ & $\begin{array}{l}-0.002 \\
(-0.05)\end{array}$ & $\begin{array}{l}0.036 \\
(0.53)\end{array}$ & $\begin{array}{l}0.040 \\
(0.59)\end{array}$ \\
\hline Bsize & $\begin{array}{l}0.014 \\
(1.26)\end{array}$ & $\begin{array}{l}0.013 \\
(1.24)\end{array}$ & $\begin{array}{l}0.016 \\
(1.48)\end{array}$ & $\begin{array}{l}0.009 \\
(0.69)\end{array}$ & $\begin{array}{l}0.008 \\
(0.66)\end{array}$ & $\begin{array}{l}0.021 \\
(1.00)\end{array}$ & $\begin{array}{l}0.020 \\
(0.96)\end{array}$ \\
\hline CEOage & $\begin{array}{l}-0.065^{\text {*** }} \\
(-4.31)\end{array}$ & $\begin{array}{l}-0.063^{* * *} \\
(-4.17)\end{array}$ & $\begin{array}{l}-0.060^{* * *} \\
(-3.96)\end{array}$ & $\begin{array}{l}-0.071^{* * *} \\
(-3.73)\end{array}$ & $\begin{array}{l}-0.068^{* * *} \\
(-3.54)\end{array}$ & $\begin{array}{l}-0.035 \\
(-1.37)\end{array}$ & $\begin{array}{l}-0.038 \\
(-1.48)\end{array}$ \\
\hline CEOtenure & $\begin{array}{l}0.000 \\
(0.04)\end{array}$ & $\begin{array}{l}-0.000 \\
(-0.02)\end{array}$ & $\begin{array}{l}0.000 \\
(0.04)\end{array}$ & $\begin{array}{l}-0.005 \\
(-0.76)\end{array}$ & $\begin{array}{l}-0.005 \\
(-0.79)\end{array}$ & $\begin{array}{l}0.010 \\
(1.07)\end{array}$ & $\begin{array}{l}0.009 \\
(0.98)\end{array}$ \\
\hline CEOShare & $\begin{array}{l}1.374^{\text {*** }} \\
(7.32)\end{array}$ & $\begin{array}{l}1.408^{* * *} \\
(7.51)\end{array}$ & $\begin{array}{l}1.292^{* * *} \\
(6.79)\end{array}$ & $\begin{array}{l}1.969^{* * *} \\
(2.64)\end{array}$ & $\begin{array}{l}2.053^{\text {*** }} \\
(2.76)\end{array}$ & $\begin{array}{l}1.183^{\text {*** }} \\
(5.51)\end{array}$ & $\begin{array}{l}1.210^{* * *} \\
(5.65)\end{array}$ \\
\hline $\mathrm{CF}$ & $\begin{array}{l}0.062^{\text {*** }} \\
(8.16)\end{array}$ & $\begin{array}{l}0.063^{* * *} \\
(8.29)\end{array}$ & $\begin{array}{l}0.062^{* * *} \\
(8.17)\end{array}$ & $\begin{array}{l}0.065^{* * *} \\
(6.58)\end{array}$ & $\begin{array}{l}0.067^{\text {*** }} \\
(6.69)\end{array}$ & $\begin{array}{l}0.058^{* * *} \\
(4.88)\end{array}$ & $\begin{array}{l}0.058^{* * *} \\
(4.90)\end{array}$ \\
\hline Sales $t-1$ & $\begin{array}{l}0.012^{\text {*** }} \\
(10.87)\end{array}$ & $\begin{array}{l}0.011^{* * *} \\
(10.82)\end{array}$ & $\begin{array}{l}0.012^{* * *} \\
(10.87)\end{array}$ & $\begin{array}{l}0.010^{* * *} \\
(7.36)\end{array}$ & $\begin{array}{l}0.010^{* * *} \\
(7.30)\end{array}$ & $\begin{array}{l}0.014^{\text {*** }} \\
(7.69)\end{array}$ & $\begin{array}{l}0.014^{* * *} \\
(7.72)\end{array}$ \\
\hline Roa & $\begin{array}{l}0.409^{* * *} \\
(10.46)\end{array}$ & $\begin{array}{l}0.391^{\text {*** }} \\
(10.00)\end{array}$ & $\begin{array}{l}0.405^{\text {*** }} \\
(10.34)\end{array}$ & $\begin{array}{l}0.433^{\text {*** }} \\
(8.72)\end{array}$ & $\begin{array}{l}0.417^{\text {*** }} \\
(8.39)\end{array}$ & $\begin{array}{l}0.330^{\text {*** }} \\
(5.08)\end{array}$ & $\begin{array}{l}0.309^{* * *} \\
(4.76)\end{array}$ \\
\hline Size & $\begin{array}{l}0.046^{* *} \\
(17.15)\end{array}$ & $\begin{array}{l}0.047^{* * *} \\
(17.67)\end{array}$ & $\begin{array}{l}0.046^{* * *} \\
(17.27)\end{array}$ & $\begin{array}{l}0.049^{* * *} \\
(14.92)\end{array}$ & $\begin{array}{l}0.051^{\text {*** }} \\
(15.25)\end{array}$ & $\begin{array}{l}0.042^{\text {*** }} \\
(8.89)\end{array}$ & $\begin{array}{l}0.045^{\text {*** }} \\
(9.37)\end{array}$ \\
\hline Market & $\begin{array}{l}-0.009^{\text {*** }} \\
(-7.64)\end{array}$ & $\begin{array}{l}-0.008^{* * *} \\
(-7.53)\end{array}$ & $\begin{array}{l}-0.009^{* * *} \\
(-7.75)\end{array}$ & $\begin{array}{l}-0.011^{* * *} \\
(-7.40)\end{array}$ & $\begin{array}{l}-0.010^{* * *} \\
(-7.32)\end{array}$ & $\begin{array}{l}-0.006^{* * *} \\
(-3.20)\end{array}$ & $\begin{array}{l}-0.006^{* * *} \\
(-3.11)\end{array}$ \\
\hline
\end{tabular}


Table 3 (continued)

$$
\text { Total sample }
$$

(1)

(2)

(3)

SOES

(4)
Non-SOEs

(6)
(7)

Panel C. Long-term loans. Panel C reports the effect of long-term loans on investment using Tobin's Q as the proxy for firms' future growth opportunities. The model specifications are given in Regression 1 and Regression 2. The independent variable is the long-term loan ratio. The sample includes all the observations in our refined data set and the sample period is from 2000 to 2011 . t-statistics are in parentheses. *, **, ${ }^{* * *}$ denote significance levels of $10 \%, 5 \%$, and $1 \%$, respectively, two-tailed.

\begin{tabular}{llllll} 
Industry dummy & Included & Included & Included & Included & Included \\
Year dummy & Included & Included & Included & Included & $\begin{array}{l}\text { Included } \\
\text { Included }\end{array}$ \\
Adjusted R ${ }^{2}$ & 0.1276 & 0.1303 & 0.1280 & 0.1285 & 0.1306 \\
Observations & 10,451 & 10,451 & 10,451 & 6945 & 0.1303 \\
\hline
\end{tabular}

2006; Aivazian et al., 2005; Firth et al., 2008) and also supports Hypothesis 1a. In order to investigate whether the negative coefficients of the total bank loan ratios support the overinvestment or the underinvestment theory, we add the interaction terms between bank loan ratios and Tobin's Q. Column (2) of Panel A shows that the coefficient of the interaction term (Debt $t_{\mathrm{i}, \mathrm{t}-1} \times \mathrm{DQ}_{\mathrm{i}, \mathrm{t}-1)}$ ) is positive and significant at the $1 \%$ level, suggesting that the negative relation between bank loan ratios and investment is weaker for high-growth firms than for low-growth firms. This result is consistent with the studies of Aivazian et al. (2005) and Ahn et al. (2006), and supports the overinvestment theory. Our results are contrary to those of Firth et al. (2008), which support the underinvestment theory.

Two reasons may explain why Firth et al. (2008) and our study draw opposite conclusions. The first is that the sample periods in these two papers do not completely overlap. Our sample period is from 2000 to 2011, while Firth et al. (2008) use data from 1991 to $2004 .{ }^{16}$ The data of Firth et al. (2008) cover the mid-1990s, during which credit allocation by Chinese state-owned banks was much more inefficient than it is during our sample period. Chinese state-owned banks had been forced to bail out poorly performing SOEs during the mid-1990s (Cull \& Xu, 2003; Park \& Sehrt, 2001). The other possible reason is the data bias. There could be extreme outliers in the data of Firth et al. (2008). In their sample, the minimum (maximum) of Tobin's Q is 0.267 (8.569), with a standard deviation of 0.731 , and the minimum (maximum) growth rate is 2.312 (23.122), with a standard deviation of 1.034. Meanwhile, in our data sample, the minimum (maximum) of Tobin's $Q$ is 0.977 (4.419), with a standard deviation of 0.775 , and the minimum (maximum) growth rate is -0.321 (1.650), with a standard deviation of 0.359 . In our empirical studies, we winsorize our sample data at the $2.5 \%$ level on both sides. The effect of extreme outliers has been alleviated in our analysis. Overall, our study indicates that the high level of state ownership in Chinese state-owned banks does not prevent them from fulfilling the disciplining role in the Chinese financial market, especially for firms with low growth.

Our results are also contrary to those of Tian and Estrin (2007). They find a positive relation between leverage and investment for Chinese publicly listed firms. Our findings are different from Tian and Estrin (2007) because Tian and Estrin (2007) use the current debt ratio as the dependent variable in their regression models, while we follow previous literature (Chen et al., 2011; Firth et al., 2008) and use the lagged debt ratio instead. The potential endogeneity problem between leverage and investment can be mitigated if the lagged debt ratio is the dependent variable. For example, firms may use the incremental bank loans to finance the investment in the same year, which would cause the contemporaneous positive relationship between leverage and investment.

To differentiate the roles of bank loans in SOEs and non-SOEs, we add the interaction term between bank loan ratios and nature $\left(\right.$ Debt $_{\mathrm{i}, \mathrm{t}-1} \times$ Nature $_{\mathrm{i}}$ ) into the regression model. Nature $\mathrm{i}_{\mathrm{i}}$ is equal to 1 if the ultimate controller of firm i is an individual and 0 otherwise. Column (3) in Panel A shows that the coefficient of the interaction term is negative and significant at the $1 \%$ level. The result supports Hypothesis $1 \mathrm{~b}$ that the disciplining role of the state-owned banks on overinvestment is weaker in SOEs than in non-SOEs. Kornai et al. (2003) offer an explanation for this discrimination that in transitional economies like China, state-owned banks usually have soft budget constraints on SOEs due to political interventions. Only the loans to non-SOEs are oriented towards profit maximization.

In Columns (4)-(7) of Panel A, we present the impact of bank loan ratios on investment for SOEs and non-SOEs, respectively. We find that the relation between bank loan ratios and investment is negative but not significant for SOEs, but the relation is negative and significant at the $1 \%$ level for non-SOEs. What is more, the coefficients of the interaction term between bank loan ratios and Tobin's $Q$ in both firm types are positive and significant at the $1 \%$ level. All these results support Hypothesis $1 \mathrm{~b}$.

Next we divide bank loans into short-term and long-term loans. The impact of short-term loan ratios on investment is reported in Panel B of Table 3. Columns (1) and (2) of Panel B show that the relation between short-term loan ratios and investment is negative and significant at the $1 \%$ level. In addition, the coefficient of the interaction term between short-term loan ratios and Tobin's $Q$ is positive and significant at the $1 \%$ level. Hypothesis $2 \mathrm{a}$ is supported. Short-term loans lent by Chinese

\footnotetext{
${ }^{16}$ SOEs dominate the sample of Firth et al. (2008), while our sample includes a large portion of non-SOEs. Our results show that the negative relation between firms' bank loan ratios and their investment is stronger for both SOEs and non-SOEs with low growth.
} 
state-owned banks serve a disciplining role on firms' overinvestment, in particular in firms with low growth. Our empirical evidence supports the theory of Diamond (1984) and Rajan (1992), showing that banks have a comparative advantage in supplying short-term loans to play a disciplining role.

Columns (3)-(7) in Panel B present the impact of short-term loan ratios on investment for SOEs and non-SOEs. Column (3) in Panel B shows that the coefficient of the interaction term between short-term loan ratios and nature is negative and significant at the $10 \%$ level, suggesting that the disciplining role of short-term loans on overinvestment in SOEs is weaker than in non-SOEs. In Columns (4)-(7) of Panel B, we divide the sample into SOEs and non-SOEs. As reported, the negative relation between short-term loan ratios and investment is indeed weaker for SOEs than for non-SOEs. The coefficient of short-term loan ratios is -0.061 and significant at the $1 \%$ level in SOEs, which is higher than -0.124 (significant at the $1 \%$ level) in non-SOEs. Similarly, the coefficients of the interaction term between short-term loan ratios and Tobin's $Q$ in both firm types are positive and significant at the $1 \%$ level. All these results support Hypothesis $2 b$.

Panel C reports the impact of long-term loan ratios on investment. As can be seen from Column (1), the relation between long-term loan ratios and investment is positive and significant at the $1 \%$ level. In Column (2), the relation between long-term loan ratios and investment is negative but not significant, while the coefficient of the interaction term between long-term loan ratios and Tobin's $Q$ is positive and significant at the $1 \%$ level. These results reject Hypothesis $3 a$ and are not consistent with Lang et al. (1996) and Aivazian et al. (2005) that show a negative relation between long-term debt ratios and investment in developed countries.

Columns (3)-(7) in Panel C present the impact of long-term loan ratios on investment for SOEs and non-SOEs. Column (3) in Panel C shows that although the coefficient of the interaction term between long-term loan ratios and nature is negative, it is not significant. This result rejects Hypothesis $3 \mathrm{~b}$, and indicates that there is no difference between SOEs and non-SOEs regarding the disciplining role of long-term loans by Chinese state-owned banks. Columns (4)-(7) in Panel C present the impact of long-term loan ratios on investment for SOEs and non-SOEs, respectively. It can be seen that the relationship between long-term loan ratios and investment for SOEs is positive, in particular for firms with high growth. However, the relation between long-term loan ratios and investment for non-SOEs is negative, and the negative relation is weaker for firms with high growth.

Consistent with prior studies, we find that Tobin's $Q$ is positively related to investment and the coefficients of the control variables acting as a proxy for financial constraints, such as cash flow, sales, profitability, and firm size, are all positive and significant. For the CEO's characteristics variables, we find that CEO age is negatively related to investment, especially for SOEs, and CEO shareholdings are positively related to investment. As for the corporate governance variables, we find that the shareholdings of the largest shareholder are positively related to investment for non-SOEs and the regional marketization level is negatively related to investment.

In summary, the results in Table 3 provide the evidence for Hypotheses 1 and 2, and reject Hypothesis 3. However, all the above results may be subject to the potential endogeneity problem between leverage and investment. Because a firm's leverage may be affected by expected investment opportunities, it is possible that leverage is endogenously determined by firm characteristics rather than exogenously given (Aivazian et al., 2005). This may be especially true for long-term loans. With the immature public corporate bond market and weak legal system, Chinese state-owned banks may be more cautious about supplying long-term loans than short-term loans. As a result, it may be easier for firms with high growth to obtain long-term loans from state-owned banks. This provides an explanation for the result that the relation between long-term loan ratios and investment is positive. Next we will deal with the potential endogeneity problem by using the instrumental variable approach and the firm fixed-effect model.

\subsection{Instrumental variables (IV) and two-stage least square regression}

In this subsection, we adopt an instrumental variable approach to deal with the potential endogeneity problem between leverage and investment. Similar to the previous studies by Aivazian et al. (2005) and Firth et al. (2008), we use the fixed-asset ratio and inventory ratio ${ }^{17}$ as the instrumental variables for bank loan ratios. Both fixed assets and inventory represent firms' asset tangibility. The tangibility of assets not only tends to reduce bankruptcy costs and therefore increase the use of leverage, but also is not highly correlated with firms' investment opportunities (Aivazian et al., 2005). We measure the fixed-asset ratio by the value of property, plant, and equipment divided by total assets. The inventory ratio is calculated by the value of inventory divided by total assets. We use two-step least square regressions. In the first step, we run the regression in which the bank loan ratio is predicted by the fixed-assets ratio and inventory ratio. Then we use the predicted value of the bank loan ratio in the second-stage regression.

Similarly, we use the inventory ratio as the instrumental variable for short-term loan ratios. The correlation between the shortterm loan ratio and the inventory ratio is 0.389 , while the correlation between investment and the inventory ratio is only -0.070 .

\footnotetext{
${ }^{17}$ We also use the asset tangibility as the instrumental variable. The tangibility of assets is the proportion of the value of property, plant, and equipment plus the value of inventory divided by total assets. We find that it is better to use the fixed-asset ratio and inventory ratio individually rather than to use asset tangibility, as the correlation between bank loan ratios and asset tangibility is 0.270 , compared with 0.613 in Aivazian et al. (2005), and the correlation between investment and asset tangibility is -0.088 , compared with -0.009 in Aivazian et al. (2005).
} 
These suggest that the inventory ratio is an appropriate instrumental variable. The correlation between the long-term loan ratio and the fixed-assets ratio is 0.302 , while the correlation between investment and the fixed-assets ratio is only -0.022 . These justify that the fixed-assets ratio is also an appropriate instrumental variable for the long-term loan ratio.

Table 4 presents the results attained by using instrumental variables. The results of Panel A and Panel B in Table 4 are similar to those in Table 3. Again, we find a negative relation between short-term loan ratios and investment, especially for firms with low growth. The negative relation between short-term loan ratios and investment is weaker for SOEs than for non-SOEs. These results provide evidence for Hypotheses 1 and 2, and suggest that our findings pertaining to the relationship between short-term loans and investment are robust after mitigating the endogeneity problem.

However, the results in Columns (1) and (2) of Panel C show that the relation between long-term loan ratios and investment is negative and significant at the $1 \%$ level, and the coefficient of the interaction term between long-term loan ratios and Tobin's $Q$ is positive and significant at the $1 \%$ level. The results support Hypothesis 3a, and suggest that long-term loans also play a disciplining role after mitigating the endogeneity problem.

Columns (3)-(7) in Panel C present the impact of long-term loan ratios on investment for SOEs and non-SOEs. As can be seen from Column (3) in Panel C, the coefficient of the interaction term between long-term loan ratios and nature is not significant. This rejects Hypothesis $3 \mathrm{~b}$, and indicates that the disciplining roles of long-term loans are not different between SOEs and non-SOEs. In Columns (4)-(7) of Panel B, we separate firms into SOEs and non-SOEs. As reported, the coefficient of long-term loan ratios is -0.599 and significant at the $1 \%$ level for SOEs, and it is -0.610 (significant at the $1 \%$ level) for non-SOEs. Why is there no difference between these two types of firms in the disciplining roles of long-term loans? One explanation is that Chinese state-owned banks discriminate against non-SOEs in lending decisions regarding long-term loans, which leads to fewer long-term loans for non-SOEs. Compared with SOEs, non-SOEs have to go through stricter and fussier screening procedures when they apply for long-term loans from state-owned banks. Similarly, the coefficients of the interaction term between long-term loan ratios and Tobin's Q in both types of firms are positive and significant at the $1 \%$ level, suggesting that long-term loans play a disciplining role in both types of firms.

\subsection{Firm fixed-effect model}

In this subsection, we use the firm fixed-effect model to deal with the potential endogeneity problem between leverage and investment. Table 5 shows that almost all the significant coefficients keep their signs as in Table 4 . These results are consistent with our previous findings.

\subsection{Sales growth as a substitute for Tobin's $Q$}

In the previous tests, we use Tobin's Q as a proxy for firms' future growth. However, the calculation of Tobin's Q might be inaccurate due to the non-tradable shares of Chinese publicly listed firms, and stock price changes tend to reflect market-level information rather than firm-specific information (Morck et al., 2000). Therefore, we also use past sales growth to capture firms' future growth and substitute Tobin's $Q$ in the following regressions. To adjust for the potential endogeneity problem between leverage and investment, especially for long-term loans, we use the instrumental variable approach and the firm fixed-effect model, respectively.

Table 6 reports the results by using the instrumental variable approach. As can be seen, almost all the significant coefficients keep their signs as before. The relation between short-term loan ratios and investment is still negative, especially for firms with low growth. The relation between long-term loan ratios and investment is still negative and significant. Similarly, the coefficients of the interaction term between short-term loan ratios and nature remain negative and significant. The coefficients of the interaction term between long-term loan ratios and nature are still negative but not significant. These results are consistent with our previous findings. In unreported tests, we find similar results by using the firm fixed-effect model.

\subsection{Comparison of the disciplining roles between short-term and long-term loans}

Table 7 reports the results comparing the disciplining roles between short-term and long-term loans. We use the ordinary least square regression (OLS), the instrumental variable approach (IV), and the firm fixed-effect model (FEM), respectively. As can be seen in Columns (1)-(3), no matter which method is used, the relation between bank loan ratios and investment is significantly negative and the coefficient of the interaction term $\left(\mathrm{Debt}_{\mathrm{i}, \mathrm{t}-1} \times \mathrm{DM}_{\mathrm{i}, \mathrm{t}-1}\right)$ is negative and significant at the $1 \%$ level. These results support Hypothesis 4, suggesting that Chinese state-owned banks mainly use short-term loans rather than long-term loans to exercise their disciplining role. Columns (4)-(6) in Table 7 present the results achieved using sales growth as a substitute for Tobin's Q, which are robust.

\subsection{The effect of China's banking reform in 2003}

After China joined the WTO in 2001, China's banking system and financial market speeded up its opening up to the outside world. Especially since 2003, there have been a series of important reforms in China's banking system. In order to separate the responsibilities of the PBOC for monetary policy and banking supervision, the CBRC was created in 2003. The CBRC's reform blueprint is built on international standards and best practice experiences. With the establishment of the CBRC, there were 
Table 4

Robustness tests using instrumental variables.

\begin{tabular}{|c|c|c|c|c|c|c|c|}
\hline & \multicolumn{3}{|l|}{ Total sample } & \multicolumn{2}{|l|}{ SOEs } & \multicolumn{2}{|l|}{ Non-SOEs } \\
\hline & $(1)$ & $(2)$ & (3) & $(4)$ & (5) & (6) & $(7)$ \\
\hline \multicolumn{8}{|c|}{$\begin{array}{l}\text { Panel A. Total bank loans. Panel A reports the effect of total bank loans on investment using instrumental variables: fixed-assets ratio and inventory ratio. } \\
\text { Two-step least square regressions are applied. In the first step, we run the regression in which the bank loan ratio is predicted by the fixed-assets ratio } \\
\text { and the inventory ratio. Then we use the predicted value of the bank loan ratio in the second-stage regressions which are defined in Regression } 1 \\
\text { and Regression } 2 \text {. The sample includes all the observations in our refined data set and the sample period is from } 2000 \text { to } 2011 \text {. t-statistics are in parentheses. } \\
*^{* *},{ }^{* * *} \text { denote significance levels of } 10 \%, 5 \% \text {, and } 1 \% \text {, respectively, two-tailed. }\end{array}$} \\
\hline Intercept & $-0.689^{* * *}$ & $-0.752^{* * *}$ & $-0.743^{\text {*** }}$ & $-0.713^{* * *}$ & $-0.779^{* * *}$ & $-0.725^{\text {*** }}$ & $-0.791^{* * *}$ \\
\hline Debt $_{t-1}$ & $\begin{array}{l}(-8.83) \\
-0.637^{\text {*** }} \\
(-9.03)\end{array}$ & $\begin{array}{l}(-9.62) \\
-0.743^{* * *} \\
(-10.39)\end{array}$ & $\begin{array}{l}(-9.22) \\
-0.530^{* * *} \\
(-6.41)\end{array}$ & $\begin{array}{l}(-7.23) \\
-0.600^{* * *} \\
(-6.85)\end{array}$ & $\begin{array}{l}(-7.87) \\
-0.682^{* * *} \\
(-7.72)\end{array}$ & $\begin{array}{l}(-5.15) \\
-0.751^{* * *} \\
(-6.18)\end{array}$ & $\begin{array}{l}(-5.62) \\
-0.908^{* * *} \\
(-7.29)\end{array}$ \\
\hline $\operatorname{Debt}_{\mathrm{t}-1} \times \mathrm{DQ}_{\mathrm{t}-1}$ & & $\begin{array}{l}0.177^{* * *} \\
(8.15)\end{array}$ & & & $\begin{array}{l}0.162^{* * *} \\
(6.15)\end{array}$ & & $\begin{array}{l}0.212^{* * *} \\
(5.42)\end{array}$ \\
\hline Debt $_{\mathrm{t}-1} \times$ Nature & & & $\begin{array}{l}-0.280^{* *} \\
(-2.32)\end{array}$ & & & & \\
\hline Nature & & & $\begin{array}{l}0.074^{* * *} \\
(2.58)\end{array}$ & & & & \\
\hline$Q_{t-1}$ & $\begin{array}{l}0.029^{* * *} \\
(7.95)\end{array}$ & $\begin{array}{l}0.012^{* * *} \\
(2.83)\end{array}$ & $\begin{array}{l}0.029^{* * *} \\
(7.92)\end{array}$ & $\begin{array}{l}0.035^{* * *} \\
(7.21)\end{array}$ & $\begin{array}{l}0.017^{\text {*** }} \\
(3.04)\end{array}$ & $\begin{array}{l}0.024^{* * *} \\
(4.04)\end{array}$ & $\begin{array}{l}0.006 \\
(0.93)\end{array}$ \\
\hline Topshare & $\begin{array}{l}0.004 \\
(0.27)\end{array}$ & $\begin{array}{l}0.005 \\
(0.37)\end{array}$ & $\begin{array}{l}0.009 \\
(0.67)\end{array}$ & $\begin{array}{l}-0.025 \\
(-1.51)\end{array}$ & $\begin{array}{l}-0.025 \\
(-1.50)\end{array}$ & $\begin{array}{l}0.090^{* * *} \\
(3.25)\end{array}$ & $\begin{array}{l}0.095^{* * *} \\
(3.44)\end{array}$ \\
\hline Director & $\begin{array}{l}0.008 \\
(1.35)\end{array}$ & $\begin{array}{l}0.007 \\
(1.20)\end{array}$ & $\begin{array}{l}0.007 \\
(1.22)\end{array}$ & $\begin{array}{l}0.002 \\
(0.21)\end{array}$ & $\begin{array}{l}0.001 \\
(0.09)\end{array}$ & $\begin{array}{l}0.011 \\
(1.07)\end{array}$ & $\begin{array}{l}0.009 \\
(0.90)\end{array}$ \\
\hline Indepen & $\begin{array}{l}0.018 \\
(0.50)\end{array}$ & $\begin{array}{l}0.012 \\
(0.33)\end{array}$ & $\begin{array}{l}0.016 \\
(0.43)\end{array}$ & $\begin{array}{l}0.006 \\
(0.15)\end{array}$ & $\begin{array}{l}-0.001 \\
(-0.03)\end{array}$ & $\begin{array}{l}0.028 \\
(0.41)\end{array}$ & $\begin{array}{l}0.022 \\
(0.32)\end{array}$ \\
\hline Bsize & $\begin{array}{l}0.017 \\
(1.55)\end{array}$ & $\begin{array}{l}0.015 \\
(1.40)\end{array}$ & $\begin{array}{l}0.018^{*} \\
(1.69)\end{array}$ & $\begin{array}{l}0.011 \\
(0.87)\end{array}$ & $\begin{array}{l}0.011 \\
(0.87)\end{array}$ & $\begin{array}{l}0.022 \\
(1.05)\end{array}$ & $\begin{array}{l}0.016 \\
(0.76)\end{array}$ \\
\hline CEOage & $\begin{array}{l}-0.061^{* * *} \\
(-4.08)\end{array}$ & $\begin{array}{l}-0.058^{* * *} \\
(-3.89)\end{array}$ & $\begin{array}{l}-0.057^{\text {*** }} \\
(-3.77)\end{array}$ & $\begin{array}{l}-0.070^{* * *} \\
(-3.67)\end{array}$ & $\begin{array}{l}-0.065^{* * *} \\
(-3.41)\end{array}$ & $\begin{array}{l}-0.029 \\
(-1.15)\end{array}$ & $\begin{array}{l}-0.029 \\
(-1.14)\end{array}$ \\
\hline CEOtenure & $\begin{array}{l}0.001 \\
(0.29)\end{array}$ & $\begin{array}{l}0.001 \\
(0.19)\end{array}$ & $\begin{array}{l}0.001 \\
(0.26)\end{array}$ & $\begin{array}{l}-0.003 \\
(-0.48)\end{array}$ & $\begin{array}{l}-0.004 \\
(-0.58)\end{array}$ & $\begin{array}{l}0.010 \\
(1.08)\end{array}$ & $\begin{array}{l}0.009 \\
(1.02)\end{array}$ \\
\hline CEOShare & $\begin{array}{l}1.331^{* * *} \\
(7.11)\end{array}$ & $\begin{array}{l}1.358^{* * *} \\
(7.28)\end{array}$ & $\begin{array}{l}1.261^{* * *} \\
(6.66)\end{array}$ & $\begin{array}{l}1.624^{* *} \\
(2.18)\end{array}$ & $\begin{array}{l}1.741^{* *} \\
(2.34)\end{array}$ & $\begin{array}{l}1.178^{* * *} \\
(5.52)\end{array}$ & $\begin{array}{l}1.192^{* * *} \\
(5.61)\end{array}$ \\
\hline $\mathrm{CF}$ & $\begin{array}{l}0.057^{* * *} \\
(7.44)\end{array}$ & $\begin{array}{l}0.058^{* * *} \\
(7.60)\end{array}$ & $\begin{array}{l}0.057^{* * *} \\
(7.47)\end{array}$ & $\begin{array}{l}0.060^{* * *} \\
(6.02)\end{array}$ & $\begin{array}{l}0.061^{* * *} \\
(6.16)\end{array}$ & $\begin{array}{l}0.053^{* * *} \\
(4.48)\end{array}$ & $\begin{array}{l}0.054^{* * *} \\
(4.59)\end{array}$ \\
\hline Sales $_{t-1}$ & $\begin{array}{l}0.007^{\text {*** }} \\
(5.83)\end{array}$ & $\begin{array}{l}0.007^{\text {*** }} \\
(5.59)\end{array}$ & $\begin{array}{l}0.007^{\text {*** }} \\
(5.88)\end{array}$ & $\begin{array}{l}0.005^{* * *} \\
(3.42)\end{array}$ & $\begin{array}{l}0.005^{\text {*** }} \\
(3.31)\end{array}$ & $\begin{array}{l}0.009^{* * *} \\
(4.54)\end{array}$ & $\begin{array}{l}0.008^{* * *} \\
(4.28)\end{array}$ \\
\hline Roa & $\begin{array}{l}0.420^{* * *} \\
(10.78)\end{array}$ & $\begin{array}{l}0.387^{* * *} \\
(9.90)\end{array}$ & $\begin{array}{l}0.414^{* * *} \\
(10.62)\end{array}$ & $\begin{array}{l}0.444^{* * *} \\
(8.97)\end{array}$ & $\begin{array}{l}0.408^{* * *} \\
(8.21)\end{array}$ & $\begin{array}{l}0.337^{* * *} \\
(5.21)\end{array}$ & $\begin{array}{l}0.307^{* * *} \\
(4.74)\end{array}$ \\
\hline Size & $\begin{array}{l}0.052^{* * *} \\
(19.97)\end{array}$ & $\begin{array}{l}0.057^{* * *} \\
(21.31)\end{array}$ & $\begin{array}{l}0.052^{* * *} \\
(20.04)\end{array}$ & $\begin{array}{l}0.056^{* * *} \\
(17.34)\end{array}$ & $\begin{array}{l}0.060^{* * *} \\
(18.28)\end{array}$ & $\begin{array}{l}0.048^{* * *} \\
(10.36)\end{array}$ & $\begin{array}{l}0.054^{* * *} \\
(11.37)\end{array}$ \\
\hline Market & $\begin{array}{l}-0.009^{* *} \\
(-7.96)\end{array}$ & $\begin{array}{l}-0.009^{* * *} \\
(-8.02)\end{array}$ & $\begin{array}{l}-0.009^{* * *} \\
(-8.09)\end{array}$ & $\begin{array}{l}-0.011^{* *} \\
(-7.67)\end{array}$ & $\begin{array}{l}-0.011^{\text {*** }} \\
(-7.75)\end{array}$ & $\begin{array}{l}-0.006^{* * *} \\
(-3.19)\end{array}$ & $\begin{array}{l}-0.006^{* * *} \\
(-3.12)\end{array}$ \\
\hline Industry dummy & Included & Included & Included & Included & Included & Included & Included \\
\hline Year dummy & Included & Included & Included & Included & Included & Included & Included \\
\hline Adjusted $\mathrm{R}^{2}$ & 0.1337 & 0.1391 & 0.1342 & 0.1334 & 0.1380 & 0.1397 & 0.1467 \\
\hline Observations & 10,451 & 10,451 & 10,451 & 6945 & 6945 & 3506 & 3506 \\
\hline
\end{tabular}

Panel B. Short-term loans. Panel B reports the effect of short-term loans on investment using the instrumental variable: inventory ratio. Two-step least square regressions are applied. In the first step, we run the regression in which the short-term loan ratio is predicted by the inventory ratio. Then we use the predicted value of the short-term loan ratio in the second-stage regressions which are defined in Regression 1 and Regression 2 . The sample includes all the observations in our refined data set and the sample period is from 2000 to 2011. t-statistics are in parentheses. *, **, *** denote significance levels of $10 \%, 5 \%$, and $1 \%$, respectively, two-tailed.

\begin{tabular}{|c|c|c|c|c|c|c|c|}
\hline Intercept & $\begin{array}{l}-0.164 \\
(-1.21)\end{array}$ & $\begin{array}{l}-0.243^{*} \\
(-1.80)\end{array}$ & $\begin{array}{l}-0.161 \\
(-1.03)\end{array}$ & $\begin{array}{l}-0.262 \\
(-1.49)\end{array}$ & $\begin{array}{l}-0.341^{*} \\
(-1.95)\end{array}$ & $\begin{array}{l}-0.139 \\
(-0.62)\end{array}$ & $\begin{array}{l}-0.234 \\
(-1.04)\end{array}$ \\
\hline Sdebt $_{\mathrm{t}-1}$ & $\begin{array}{l}-3.021^{* * *} \\
(-5.25)\end{array}$ & $\begin{array}{l}-3.054^{\text {*** }} \\
(-5.32)\end{array}$ & $\begin{array}{l}-2.231^{\text {*** }} \\
(-4.66)\end{array}$ & $\begin{array}{l}-2.649^{* * *} \\
(-3.56)\end{array}$ & $\begin{array}{l}-2.700^{* * *} \\
(-3.64)\end{array}$ & $\begin{array}{l}-3.515^{* * *} \\
(-3.71)\end{array}$ & $\begin{array}{l}-3.465^{* * *} \\
(-3.67)\end{array}$ \\
\hline $\operatorname{Sdebt}_{\mathrm{t}-1} \times \mathrm{DQ}_{\mathrm{t}-1}$ & & $\begin{array}{l}0.228^{* * *} \\
(8.40)\end{array}$ & & & $\begin{array}{l}0.220^{* * *} \\
(6.61)\end{array}$ & & $\begin{array}{l}0.243^{* * *} \\
(5.06)\end{array}$ \\
\hline Sdebt $_{t-1} \times$ Nature & & & $\begin{array}{l}-1.568^{* *} \\
(-2.10)\end{array}$ & & & & \\
\hline Nature & & & $\begin{array}{l}-0.100 \\
(-0.54)\end{array}$ & & & & \\
\hline$Q_{t-1}$ & $\begin{array}{l}0.029^{* * *} \\
(7.76)\end{array}$ & $\begin{array}{l}0.010^{* *} \\
(2.44)\end{array}$ & $\begin{array}{l}0.029^{* * *} \\
(7.75)\end{array}$ & $\begin{array}{l}0.034^{\text {*** }} \\
(7.01)\end{array}$ & $\begin{array}{l}0.014^{* *} \\
(2.55)\end{array}$ & $\begin{array}{l}0.023^{* * *} \\
(3.96)\end{array}$ & $\begin{array}{l}0.007 \\
(0.99)\end{array}$ \\
\hline Topshare & $\begin{array}{l}0.002 \\
(0.16)\end{array}$ & $\begin{array}{l}0.004 \\
(0.31)\end{array}$ & $\begin{array}{l}0.008 \\
(0.56)\end{array}$ & $\begin{array}{l}-0.025 \\
(-1.49)\end{array}$ & $\begin{array}{l}-0.024 \\
(-1.42)\end{array}$ & $\begin{array}{l}0.090^{* * *} \\
(3.26)\end{array}$ & $\begin{array}{l}0.095^{* * *} \\
(3.43)\end{array}$ \\
\hline
\end{tabular}


Table 4 (continued)

\begin{tabular}{|c|c|c|c|c|c|c|c|}
\hline & \multicolumn{3}{|l|}{ Total sample } & \multicolumn{2}{|l|}{ SOES } & \multicolumn{2}{|l|}{ Non-SOEs } \\
\hline & $(1)$ & $(2)$ & (3) & $(4)$ & $(5)$ & (6) & (7) \\
\hline \multicolumn{8}{|c|}{$\begin{array}{l}\text { Panel B. Short-term loans. Panel B reports the effect of short-term loans on investment using the instrumental variable: inventory ratio. Two-step least square } \\
\text { regressions are applied. In the first step, we run the regression in which the short-term loan ratio is predicted by the inventory ratio. Then we use the } \\
\text { predicted value of the short-term loan ratio in the second-stage regressions which are defined in Regression } 1 \text { and Regression } 2 \text {. The sample includes all the } \\
\text { observations in our refined data set and the sample period is from } 2000 \text { to } 2011 \text { t t-statistics are in parentheses. }{ }^{*}, * * * * * \text { denote significance levels of } 10 \%, 5 \% \text {, } \\
\text { and } 1 \% \text {, respectively, two-tailed. }\end{array}$} \\
\hline Director & $\begin{array}{l}0.009 \\
(1.50)\end{array}$ & $\begin{array}{l}0.008 \\
(1.35)\end{array}$ & $\begin{array}{l}0.009 \\
(1.41)\end{array}$ & $\begin{array}{l}0.003 \\
(0.28)\end{array}$ & $\begin{array}{l}0.001 \\
(0.17)\end{array}$ & $\begin{array}{l}0.012 \\
(1.19)\end{array}$ & $\begin{array}{l}0.010 \\
(1.05)\end{array}$ \\
\hline Indepen & $\begin{array}{l}0.018 \\
(0.51)\end{array}$ & $\begin{array}{l}0.012 \\
(0.33)\end{array}$ & $\begin{array}{l}0.018 \\
(0.48)\end{array}$ & $\begin{array}{l}0.004 \\
(0.09)\end{array}$ & $\begin{array}{l}-0.005 \\
(-0.12)\end{array}$ & $\begin{array}{l}0.035 \\
(0.51)\end{array}$ & $\begin{array}{l}0.030 \\
(0.44)\end{array}$ \\
\hline Bsize & $\begin{array}{l}0.014 \\
(1.28)\end{array}$ & $\begin{array}{l}0.012 \\
(1.15)\end{array}$ & $\begin{array}{l}0.016 \\
(1.52)\end{array}$ & $\begin{array}{l}0.009 \\
(0.68)\end{array}$ & $\begin{array}{l}0.009 \\
(0.69)\end{array}$ & $\begin{array}{l}0.021 \\
(1.01)\end{array}$ & $\begin{array}{l}0.016 \\
(0.76)\end{array}$ \\
\hline CEOage & $\begin{array}{l}-0.065^{* * *} \\
(-4.30)\end{array}$ & $\begin{array}{l}-0.062^{* * *} \\
(-4.14)\end{array}$ & $\begin{array}{l}-0.060^{* * *} \\
(-3.98)\end{array}$ & $\begin{array}{l}-0.071^{* * *} \\
(-3.73)\end{array}$ & $\begin{array}{l}-0.066 * * * \\
(-3.47)\end{array}$ & $\begin{array}{l}-0.034 \\
(-1.33)\end{array}$ & $\begin{array}{l}-0.034 \\
(-1.36)\end{array}$ \\
\hline CEOtenure & $\begin{array}{l}0.001 \\
(0.20)\end{array}$ & $\begin{array}{l}0.001 \\
(0.10)\end{array}$ & $\begin{array}{l}0.001 \\
(0.21)\end{array}$ & $\begin{array}{l}-0.004 \\
(-0.62)\end{array}$ & $\begin{array}{l}-0.004 \\
(-0.72)\end{array}$ & $\begin{array}{l}0.010 \\
(1.13)\end{array}$ & $\begin{array}{l}0.010 \\
(1.06)\end{array}$ \\
\hline CEOShare & $\begin{array}{l}1.353^{* * *} \\
(7.21)\end{array}$ & $\begin{array}{l}1.372^{* * *} \\
(7.34)\end{array}$ & $\begin{array}{l}1.290^{* * *} \\
(6.80)\end{array}$ & $\begin{array}{l}1.833^{* *} \\
(2.46)\end{array}$ & $\begin{array}{l}1.925^{\text {**** }} \\
(2.59)\end{array}$ & $\begin{array}{l}1.195^{* * *} \\
(5.58)\end{array}$ & $\begin{array}{l}1.201^{* * *} \\
(5.63)\end{array}$ \\
\hline $\mathrm{CF}$ & $\begin{array}{l}0.061^{* * *} \\
(7.99)\end{array}$ & $\begin{array}{l}0.061^{* * *} \\
(8.10)\end{array}$ & $\begin{array}{l}0.061^{* * *} \\
(8.03)\end{array}$ & $\begin{array}{l}0.064^{* * *} \\
(6.45)\end{array}$ & $\begin{array}{l}0.065^{* * *} \\
(6.54)\end{array}$ & $\begin{array}{l}0.057^{* * *} \\
(4.81)\end{array}$ & $\begin{array}{l}0.058^{* * *} \\
(4.91)\end{array}$ \\
\hline Sales $t-1$ & $\begin{array}{l}0.013^{* * *} \\
(11.63)\end{array}$ & $\begin{array}{l}0.013^{* * *} \\
(11.54)\end{array}$ & $\begin{array}{l}0.013^{* * *} \\
(11.61)\end{array}$ & $\begin{array}{l}0.011^{* * *} \\
(7.73)\end{array}$ & $\begin{array}{l}0.011^{* * *} \\
(7.72)\end{array}$ & $\begin{array}{l}0.015^{* * *} \\
(8.41)\end{array}$ & $\begin{array}{l}0.015^{* * *} \\
(8.26)\end{array}$ \\
\hline Roa & $\begin{array}{l}0.403^{\text {*** }} \\
(10.31)\end{array}$ & $\begin{array}{l}0.367^{\text {**** }} \\
(9.36)\end{array}$ & $\begin{array}{l}0.397^{* * * *} \\
(10.15)\end{array}$ & $\begin{array}{l}0.424^{* * *} \\
(8.55)\end{array}$ & $\begin{array}{l}0.385^{* * *} \\
(7.75)\end{array}$ & $\begin{array}{l}0.324^{* * *} \\
(4.98)\end{array}$ & $\begin{array}{l}0.291^{* * *} \\
(4.48)\end{array}$ \\
\hline Size & $\begin{array}{l}0.048^{* * *} \\
(18.80)\end{array}$ & $\begin{array}{l}0.053^{\text {*** }} \\
(20.21)\end{array}$ & $\begin{array}{l}0.050^{* * *} \\
(18.91)\end{array}$ & $\begin{array}{l}0.052^{* * *} \\
(16.41)\end{array}$ & $\begin{array}{l}0.057^{* * *} \\
(17.47)\end{array}$ & $\begin{array}{l}0.050^{* * *} \\
(9.70)\end{array}$ & $\begin{array}{l}0.050^{* * *} \\
(10.60)\end{array}$ \\
\hline Market & $\begin{array}{l}-0.009^{* * *} \\
(-8.00)\end{array}$ & $\begin{array}{l}-0.009^{* * * *} \\
(-8.05)\end{array}$ & $\begin{array}{l}-0.009^{* * *} \\
(-8.12)\end{array}$ & $\begin{array}{l}-0.011^{* * *} \\
(-7.76)\end{array}$ & $\begin{array}{l}-0.011^{* * *} \\
(-7.84)\end{array}$ & $\begin{array}{l}-0.006^{* * *} \\
(-3.27)\end{array}$ & $\begin{array}{l}-0.006^{* * *} \\
(-3.20)\end{array}$ \\
\hline Industry dummy & Included & Included & Included & Included & Included & Included & Included \\
\hline Year dummy & Included & Included & Included & Included & Included & Included & Included \\
\hline Adjusted $\mathrm{R}^{2}$ & 0.1292 & 0.1350 & 0.1295 & 0.1291 & 0.1344 & 0.1336 & 0.1397 \\
\hline Observations & 10,451 & 10,451 & 10,451 & 6945 & 6945 & 3506 & 3506 \\
\hline
\end{tabular}

Non-SOES

Panel C. Long-term loans. Panel C reports the effect of long-term loans on investment using the instrumental variable: fixed-assets ratio. Two-step least square regressions are applied. In the first step, we run the regression in which the long-term loan ratio is predicted by the fixed-assets ratio. Then we use the predicted value of the long-term loan ratio in the second-stage regressions which are defined in Regression 1 and Regression 2 . The sample includes all the observations in our refined data set and the sample period is from 2000 to 2011 . t-statistics are in parentheses. *, **,*** denote significance levels of $10 \%$, $5 \%$, and $1 \%$, respectively, two-tailed.

\begin{tabular}{|c|c|c|c|c|c|c|c|}
\hline Intercept & & & & & & & \\
\hline Ldebt $_{\mathrm{t}-1}$ & $\begin{array}{l}(-9.76)^{* * *} \\
-0.566^{* * *} \\
(-4.48)\end{array}$ & $\begin{array}{l}(-9.67) \\
-0.665^{* * *} \\
(-5.24)\end{array}$ & $\begin{array}{l}(-10.03) \\
-0.415^{* * *} \\
(-2.91)\end{array}$ & $\begin{array}{l}(-8.08) \\
-0.599^{* * *} \\
(-3.80)\end{array}$ & $\begin{array}{l}(-8.10) \\
-0.696^{* * *} \\
(-4.40)\end{array}$ & $\begin{array}{l}(-5.61)^{* * *} \\
-0.610^{* * *} \\
(-2.82)\end{array}$ & $\begin{array}{l}(-5.29) \\
-0.720^{* * *} \\
(-3.32)\end{array}$ \\
\hline Ldebt $_{\mathrm{t}-1} \times \mathrm{DQ}_{\mathrm{t}-1}$ & & $\begin{array}{l}0.271^{\text {*** }} \\
(7.09)\end{array}$ & & & $\begin{array}{l}0.270^{* * *} \\
(5.63)\end{array}$ & & $\begin{array}{l}0.269^{* * *} \\
(4.19)\end{array}$ \\
\hline Ldebt $_{\mathrm{t}-1} \times$ Nature & & & $\begin{array}{l}-0.423 \\
(-1.45)\end{array}$ & & & & \\
\hline Nature & & & $\begin{array}{l}0.026^{* * *} \\
(2.92)\end{array}$ & & & & \\
\hline$Q_{t-1}$ & $\begin{array}{l}0.031^{\text {*** }} \\
(8.36)\end{array}$ & $\begin{array}{l}0.027^{* * *} \\
(7.14)\end{array}$ & $\begin{array}{l}0.031^{* * *} \\
(8.37)\end{array}$ & $\begin{array}{l}0.036^{* * *} \\
(7.46)\end{array}$ & $\begin{array}{l}0.031^{\text {*** }} \\
(6.41)\end{array}$ & $\begin{array}{l}0.026^{\text {*** }} \\
(4.34)\end{array}$ & $\begin{array}{l}0.022^{* * *} \\
(3.71)\end{array}$ \\
\hline Topshare & $\begin{array}{l}0.002 \\
(0.17)\end{array}$ & $\begin{array}{l}0.008 \\
(0.56)\end{array}$ & $\begin{array}{l}0.008 \\
(0.56)\end{array}$ & $\begin{array}{l}-0.024 \\
(-1.43)\end{array}$ & $\begin{array}{l}-0.019 \\
(-1.13)\end{array}$ & $\begin{array}{l}0.086^{* * *} \\
(3.10)\end{array}$ & $\begin{array}{l}0.090^{* * *} \\
(3.24)\end{array}$ \\
\hline Director & $\begin{array}{l}0.008 \\
(1.29)\end{array}$ & $\begin{array}{l}0.007 \\
(1.13)\end{array}$ & $\begin{array}{l}0.007 \\
(1.19)\end{array}$ & $\begin{array}{l}0.000 \\
(0.02)\end{array}$ & $\begin{array}{l}-0.000 \\
(-0.04)\end{array}$ & $\begin{array}{l}0.012 \\
(1.21)\end{array}$ & $\begin{array}{l}0.011 \\
(1.07)\end{array}$ \\
\hline Indepen & $\begin{array}{l}0.017 \\
(0.46)\end{array}$ & $\begin{array}{l}0.014 \\
(0.38)\end{array}$ & $\begin{array}{l}0.016 \\
(0.43)\end{array}$ & $\begin{array}{l}0.002 \\
(0.04)\end{array}$ & $\begin{array}{l}-0.002 \\
(-0.04)\end{array}$ & $\begin{array}{l}0.034 \\
(0.50)\end{array}$ & $\begin{array}{l}0.035 \\
(0.51)\end{array}$ \\
\hline Bsize & $\begin{array}{l}0.015 \\
(1.37)\end{array}$ & $\begin{array}{l}0.015 \\
(1.36)\end{array}$ & $\begin{array}{l}0.017 \\
(1.58)\end{array}$ & $\begin{array}{l}0.010 \\
(0.75)\end{array}$ & $\begin{array}{l}0.010 \\
(0.75)\end{array}$ & $\begin{array}{l}0.022 \\
(1.04)\end{array}$ & $\begin{array}{l}0.020 \\
(0.96)\end{array}$ \\
\hline CEOage & $\begin{array}{l}-0.063^{\text {*** }} \\
(-4.21)\end{array}$ & $\begin{array}{l}-0.061^{* * *} \\
(-4.05)\end{array}$ & $\begin{array}{l}-0.060^{* * *} \\
(-3.89)\end{array}$ & $\begin{array}{l}-0.071^{\text {*** }} \\
(-3.70)\end{array}$ & $\begin{array}{l}-0.066^{* * *} \\
(-3.47)\end{array}$ & $\begin{array}{l}-0.033 \\
(-1.30)\end{array}$ & $\begin{array}{l}-0.036 \\
(-1.40)\end{array}$ \\
\hline CEOtenure & $\begin{array}{l}0.001 \\
(0.14)\end{array}$ & $\begin{array}{l}0.000 \\
(0.02)\end{array}$ & $\begin{array}{l}0.001 \\
(0.12)\end{array}$ & $\begin{array}{l}-0.004 \\
(-0.62)\end{array}$ & $\begin{array}{l}-0.004 \\
(-0.69)\end{array}$ & $\begin{array}{l}0.010 \\
(1.06)\end{array}$ & $\begin{array}{l}0.008 \\
(0.94)\end{array}$ \\
\hline CEOShare & $\begin{array}{l}1.366^{\text {*** }} \\
(7.28)\end{array}$ & $\begin{array}{l}1.401^{* * *} \\
(7.48)\end{array}$ & $\begin{array}{l}1.284^{\text {*** }} \\
(6.76)\end{array}$ & $\begin{array}{l}1.910^{* *} \\
(2.56)\end{array}$ & $\begin{array}{l}1.982^{\text {*** }} \\
(2.67)\end{array}$ & $\begin{array}{l}1.171^{\text {*** }} \\
(5.46)\end{array}$ & $\begin{array}{l}1.198^{* * *} \\
(5.60)\end{array}$ \\
\hline $\mathrm{CF}$ & $\begin{array}{l}0.060^{* * *} \\
(7.84)\end{array}$ & $\begin{array}{l}0.061^{* * *} \\
(8.04)\end{array}$ & $\begin{array}{l}0.060^{* * *} \\
(7.89)\end{array}$ & $\begin{array}{l}0.063^{* * *} \\
(6.28)\end{array}$ & $\begin{array}{l}0.064^{* * *} \\
(6.45)\end{array}$ & $\begin{array}{l}0.057^{* *} \\
(4.74)\end{array}$ & $\begin{array}{l}0.057^{\text {*** }} \\
(4.82)\end{array}$ \\
\hline Sales ${ }_{t-1}$ & $\begin{array}{l}0.008^{* * *} \\
(6.49)\end{array}$ & $\begin{array}{l}0.008^{* * *} \\
(6.55)\end{array}$ & $\begin{array}{l}0.008^{* * *} \\
(6.50)\end{array}$ & $\begin{array}{l}0.006^{\text {*** }} \\
(3.70)\end{array}$ & $\begin{array}{l}0.006^{\text {*** }} \\
(3.69)\end{array}$ & $\begin{array}{l}0.011^{\text {*** }} \\
(5.21)\end{array}$ & $\begin{array}{l}0.011^{* * *} \\
(5.33)\end{array}$ \\
\hline
\end{tabular}


Table 4 (continued)

$$
\text { Total sample }
$$

(1)

(2)

SOES

(4)
Non-SOEs

(6)

(7)

Panel C. Long-term loans. Panel C reports the effect of long-term loans on investment using the instrumental variable: fixed-assets ratio. Two-step least square regressions are applied. In the first step, we run the regression in which the long-term loan ratio is predicted by the fixed-assets ratio. Then we use the predicted value of the long-term loan ratio in the second-stage regressions which are defined in Regression 1 and Regression 2 . The sample includes all the observations in our refined data set and the sample period is from 2000 to 2011 . t-statistics are in parentheses. *, **, *** denote significance levels of $10 \%$, $5 \%$, and $1 \%$, respectively, two-tailed.

\begin{tabular}{|c|c|c|c|c|c|c|c|}
\hline Roa & $\begin{array}{l}0.415^{\text {*** }} \\
(10.60)\end{array}$ & $\begin{array}{l}0.401^{* * *} \\
(10.26)\end{array}$ & $\begin{array}{l}0.408^{* * *} \\
(10.41)\end{array}$ & $\begin{array}{l}0.437^{* * *} \\
(8.81)\end{array}$ & $\begin{array}{l}0.425^{\text {*** }} \\
(8.58)\end{array}$ & $\begin{array}{l}0.337^{\text {*** }} \\
(5.19)\end{array}$ & $\begin{array}{l}0.321^{\text {*** }} \\
(4.94)\end{array}$ \\
\hline Size & $0.050^{* *}$ & $\begin{array}{l}0.050^{* * *} \\
(1885)\end{array}$ & $\begin{array}{l}0.050^{* * *} \\
(1920)\end{array}$ & $0.054^{\text {*** }}$ & $0.053^{\text {*** }}$ & $0.044^{* * *}$ & $0.043^{* * *}$ \\
\hline Market & $\begin{array}{l}-0.009^{\text {*** }} \\
(-7.92)\end{array}$ & $\begin{array}{l}-0.008^{* * *} \\
(-7.44)\end{array}$ & $\begin{array}{l}-0.009^{* * *} \\
(-8.06)\end{array}$ & $\begin{array}{l}-0.011^{* * *} \\
(-7.64)\end{array}$ & $\begin{array}{l}-0.010^{* * *} \\
(-7.27)\end{array}$ & $\begin{array}{l}-0.006^{* * *} \\
(-3.23)\end{array}$ & $\begin{array}{l}-0.005^{\text {*** }} \\
(-2.93)\end{array}$ \\
\hline Industry dummy & Included & Included & Included & Included & Included & Included & Included \\
\hline Year dummy & Included & Included & Included & Included & Included & Included & Included \\
\hline Adjusted $\mathrm{R}^{2}$ & 0.1286 & 0.1327 & 0.1292 & 0.1293 & 0.1332 & 0.1322 & 0.1363 \\
\hline Observations & 10,451 & 10,451 & 10,451 & 6945 & 6945 & 3506 & 3506 \\
\hline
\end{tabular}

several improvements (Garcia-Herrero et al., 2006) to China's banking system. At first, the loan classification system was enhanced and made fully compulsory for all banks by the end of 2005, which helps banks to review the quality of their loan portfolios more efficiently than before. It is also helpful for banks to assign loans by categories or grades based on the perceived risk and other relevant characteristics of loans. Secondly, risk-based supervision started to be implemented through a new CAMEL-type risk assessment system, which evaluates firms' asset quality, management competence, liquidity, and profitability by not only quantitative criteria but also qualitative ones. Thirdly, related-party lending has been limited. Banks lend mostly to the corporate sector, in many cases large SOEs. Lastly, governance and enforcement have been improved since the CBRC started to impose sanctions for infractions. At the same time, under the commitments of the WTO agreement in 2001, China speeded up its full opening up of the banking system to foreign affiliates. For example, the Chinese government encourages foreign banks to compete with domestic banks and has set up policies to attract strategic foreign investors to purchase shares of Chinese state-owned banks. In 2003, the wholesale market in domestic currency to Chinese enterprises was opened to foreign competition for most provinces. Also in 2003, the CBRC updated the guidelines to encourage foreign share purchases of up to $25 \%$ of any domestic bank, with the ownership from any one investor allowed between $5 \%$ and $20 \%$.

The reforms of China's banking system in 2003 may indicate that state-owned banks make more economic-oriented lending decisions and that their disciplining role has been strengthened. The negative relation between bank loans and investment is supposed to be strengthened. Table 8 reports the effect of China's banking reform in 2003 on the relation between bank loans and investment by using the instrumental variable approach. When we use the firm fixed-effect model, the results are similar. Columns (1)-(3) in Table 8 show that the coefficients of the interaction term between (long-term) bank loan variables and dummy variable Period03 are significantly positive, and the coefficient of the interaction term between short-term loan ratios and dummy variable Period03 is positive, but not significant. This suggests that the reform of China's banking system in 2003 has weakened the disciplining role of the state-owned banks, especially the disciplining role of long-term loans. Columns (4)-(9) present the impact of China's banking system reforms in 2003 on SOEs and non-SOEs, respectively. It can be seen that in SOEs, the coefficients of the interaction term between bank loan variables and dummy variable Period03 are similar to those in Columns (1)-(3), and in non-SOEs, the coefficients of the interaction term between bank loan variables and dummy variable Period03 are all positive but not significant. These results suggest that the reform of China's banking system in 2003 has weakened the disciplining role of the state-owned banks in SOEs but not in non-SOEs, especially the disciplining role of long-term loans.

In brief, China's banking system implemented significant reforms in 2003, such as the establishment of the CBRC, introducing more foreign banks' competition, and speeding up the process of attracting strategic foreign investors. However, the results in Table 8 show that the disciplining role of Chinese state-owned banks in SOEs and non-SOEs has not been strengthened since the 2003 reform. For SOEs, the disciplining role of the state-owned banks has even been weakened, especially regarding long-term loans.

\section{Conclusions}

In this paper, we examine the relation between firms' leverage and investment by focusing on publicly listed firms in China. After mitigating the potential endogeneity problem between leverage and investment, we find that there is a negative relation between bank loan ratios and investment for Chinese publicly listed firms and that the correlation is much stronger for firms with low growth. This result is consistent with the evidence in developed markets such as the U.S. and Canada, but partly consistent with the findings of Firth et al. (2008). When we separate bank loans into short-term and long-term loans, we find that both 
Table 5

Robustness tests using the firm fixed-effect model.

\begin{tabular}{|c|c|c|c|c|c|c|c|}
\hline & \multicolumn{3}{|l|}{ Total sample } & \multicolumn{2}{|l|}{ SOEs } & \multicolumn{2}{|l|}{ Non-SOEs } \\
\hline & (1) & $(2)$ & (3) & $(4)$ & $(5)$ & $(6)$ & $(7)$ \\
\hline \multicolumn{8}{|c|}{$\begin{array}{l}\text { Panel A. Total bank loans. Panel A reports the effect of total bank loans on investment using the firm fixed-effect model. The model specifications are given in } \\
\text { Regression } 1 \text { and Regression } 2 \text {. The independent variable is the total bank loan ratio. The sample includes all the observations in our refined data set and the } \\
\text { sample period is from } 2000 \text { to } 2011 \text {. t-statistics are in parentheses. }{ }^{*}{ }^{* *} \text {, }{ }^{* *} \text { denote significance levels of } 10 \%, 5 \% \text {, and } 1 \% \text {, respectively, two-tailed. }\end{array}$} \\
\hline \multirow[t]{2}{*}{ Intercept } & $-2.237^{* * *}$ & $-2.350^{* * *}$ & $-2.234^{* * *}$ & $-2.443^{* * *}$ & $-2.565^{* * *}$ & $-2.350^{* * *}$ & $-2.406^{* * *}$ \\
\hline & $(-14.81)$ & $(-15.55)$ & $(-14.76)$ & $(-12.71)$ & $(-13.33)$ & $(-8.23)$ & $(-8.44)$ \\
\hline \multirow[t]{2}{*}{ Debt $_{t-1}$} & $-0.297^{* * *}$ & $-0.373^{* * *}$ & $-0.281^{* * *}$ & $-0.287^{* * *}$ & $-0.353^{* * *}$ & $-0.339^{* * *}$ & $-0.432^{* * *}$ \\
\hline & $(-13.09)$ & $(-15.27)$ & $(-10.71)$ & $(-10.05)$ & $(-11.68)$ & $(-7.96)$ & $(-9.15)$ \\
\hline \multirow{2}{*}{$\operatorname{Debt}_{t-1} \times \mathrm{DQ}_{\mathrm{t}-1}$} & & $0.156^{* * *}$ & & & $0.156^{* * *}$ & & $0.156^{* * *}$ \\
\hline & & $(8.20)$ & & & (6.49) & & $(4.51)$ \\
\hline Debt $_{\mathrm{t}-1} \times$ Nature & & & $\begin{array}{l}-0.047^{*} \\
(-1.78)\end{array}$ & & & & \\
\hline Nature & & & $\begin{array}{l}0.008 \\
(0.60)\end{array}$ & & & & \\
\hline \multirow[t]{2}{*}{$Q_{t-1}$} & $0.046^{* * *}$ & $0.035^{* * *}$ & $0.046^{* * *}$ & $0.048^{* * *}$ & $0.036^{* * *}$ & $0.037^{* * *}$ & $0.027^{* * *}$ \\
\hline & $(10.30)$ & $(7.47)$ & (10.27) & (8.19) & (5.89) & $(4.93)$ & $(3.45)$ \\
\hline \multirow[t]{2}{*}{ Topshare } & -0.046 & -0.043 & -0.047 & -0.010 & -0.006 & -0.074 & -0.073 \\
\hline & $(-1.55)$ & $(-1.45)$ & $(-1.58)$ & $(-0.26)$ & $(-0.15)$ & $(-1.23)$ & $(-1.21)$ \\
\hline \multirow[t]{2}{*}{ Director } & 0.001 & 0.000 & 0.001 & 0.010 & 0.008 & -0.011 & -0.011 \\
\hline & $(0.15)$ & $(0.04)$ & $(0.17)$ & $(0.84)$ & $(0.73)$ & $(-0.74)$ & $(-0.70)$ \\
\hline \multirow[t]{2}{*}{ Indepen } & 0.030 & 0.039 & 0.030 & 0.004 & 0.010 & -0.008 & 0.012 \\
\hline & $(0.68)$ & $(0.89)$ & $(0.68)$ & $(0.07)$ & $(0.18)$ & $(-0.08)$ & $(0.13)$ \\
\hline \multirow[t]{2}{*}{ Bsize } & -0.023 & -0.021 & -0.022 & -0.020 & -0.017 & -0.038 & -0.036 \\
\hline & $(-1.28)$ & $(-1.19)$ & $(-1.27)$ & $(-0.97)$ & $(-0.82)$ & $(-1.03)$ & $(-0.97)$ \\
\hline \multirow[t]{2}{*}{ CEOage } & $-0.073^{\text {*** }}$ & $-0.069^{* * *}$ & $-0.073^{* * *}$ & $-0.103^{\text {*** }}$ & $-0.096^{\text {*** }}$ & 0.035 & 0.033 \\
\hline & $(-3.40)$ & $(-3.21)$ & $(-3.39)$ & $(-3.77)$ & $(-3.52)$ & $(0.89)$ & $(0.83)$ \\
\hline \multirow[t]{2}{*}{ CEOtenure } & 0.001 & 0.000 & 0.001 & -0.003 & -0.004 & 0.012 & 0.011 \\
\hline & $(0.14)$ & $(0.06)$ & $(0.12)$ & $(-0.53)$ & $(-0.69)$ & $(1.22)$ & $(1.11)$ \\
\hline \multirow[t]{2}{*}{ CEOShare } & 0.849 & 0.876 & 0.842 & $6.227^{* *}$ & $6.128^{* *}$ & 0.467 & 0.545 \\
\hline & $(1.34)$ & $(1.38)$ & $(1.33)$ & $(2.13)$ & $(2.10)$ & $(0.67)$ & $(0.78)$ \\
\hline \multirow[t]{2}{*}{$\mathrm{CF}$} & $0.089^{* * *}$ & $0.090^{* * *}$ & $0.089^{* * *}$ & $0.097^{* * *}$ & $0.097^{* * *}$ & $0.083^{* * *}$ & $0.084^{* * *}$ \\
\hline & $(10.86)$ & $(11.05)$ & $(10.86)$ & $(8.95)$ & $(9.02)$ & $(6.17)$ & $(6.32)$ \\
\hline \multirow[t]{2}{*}{ Sales $t-1$} & $0.019^{* * *}$ & $0.018^{* * *}$ & $0.019^{* * *}$ & $0.017^{* * *}$ & $0.017^{* * *}$ & $0.020^{* * *}$ & $0.020^{* * *}$ \\
\hline & $(10.63)$ & $(10.53)$ & $(10.65)$ & $(7.49)$ & $(7.33)$ & $(6.63)$ & $(6.64)$ \\
\hline \multirow[t]{2}{*}{ Roa } & $0.132^{* * *}$ & $0.108^{* *}$ & $0.135^{* * *}$ & $0.115^{*}$ & 0.098 & 0.117 & 0.083 \\
\hline & $(2.82)$ & $(2.31)$ & $(2.89)$ & $(1.87)$ & $(1.60)$ & $(1.44)$ & $(1.02)$ \\
\hline \multirow{2}{*}{ Size } & $0.129^{* * *}$ & $0.134^{* * *}$ & $0.129^{* * *}$ & $0.139^{* * *}$ & $0.144^{* * *}$ & $0.128^{* * *}$ & $0.132^{* * *}$ \\
\hline & $(22.16)$ & $(22.98)$ & $(22.05)$ & $(18.65)$ & $(19.25)$ & $(11.52)$ & $(11.86)$ \\
\hline \multirow[t]{2}{*}{ Market } & $-0.011^{*}$ & -0.009 & $-0.011^{*}$ & 0.001 & 0.003 & $-0.034^{* * *}$ & $-0.032^{* * *}$ \\
\hline & $(-1.70)$ & $(-1.39)$ & $(-1.67)$ & $(0.12)$ & $(0.42)$ & $(-2.87)$ & $(-2.77)$ \\
\hline Industry dummy & Included & Included & Included & Included & Included & Included & Included \\
\hline Year dummy & Included & Included & Included & Included & Included & Included & Included \\
\hline Adjusted $\mathrm{R}^{2}$ & 0.1319 & 0.1384 & 0.1321 & 0.1252 & 0.1314 & 0.1550 & 0.1613 \\
\hline Observations & 10,451 & 10,451 & 10,451 & 6945 & 6945 & 3506 & 3506 \\
\hline
\end{tabular}

Panel B. Short-term loans. Panel B reports the effect of short-term loans on investment using the firm fixed-effect model. The model specifications are given in Regression 1 and Regression 2. The independent variable is the short-term loan ratio. The sample includes all the observations in our refined data set and the sample period is from 2000 to 2011 . t-statistics are in parentheses. *, **, *** denote significance levels of $10 \%, 5 \%$, and $1 \%$, respectively, two-tailed.

\begin{tabular}{|c|c|c|c|c|c|c|c|}
\hline Intercept & $-2.011^{\text {*** }}$ & $-2.092^{\text {*** }}$ & $-2.015^{* * *}$ & & & $-2.189^{\text {*** }}$ & $-2.243^{* * *}$ \\
\hline & $(-13.35)$ & $(-13.88)$ & $(-13.35)$ & $(-11.41)$ & $(-11.85)$ & $(-7.68)$ & $(-7.88)$ \\
\hline Sdebt $_{\mathrm{t}-1}$ & $\begin{array}{l}-0.266^{\text {*** }} \\
(-10.42)\end{array}$ & $\begin{array}{l}-0.349^{* * *} \\
(-12.29)\end{array}$ & $\begin{array}{l}-0.237^{\text {*** }} \\
(-7.85)\end{array}$ & $\begin{array}{l}-0.226^{\text {*** }} \\
(-6.94)\end{array}$ & $\begin{array}{l}-0.303^{* * *} \\
(-8.52)\end{array}$ & $\begin{array}{l}-0.347^{\text {*** }} \\
(-7.39)\end{array}$ & $\begin{array}{l}-0.444^{* * *} \\
(-8.34)\end{array}$ \\
\hline Sdebt $_{\mathrm{t}-1} \times \mathrm{DQ}_{\mathrm{t}-1}$ & & $\begin{array}{l}0.160^{* * *} \\
(6.61)\end{array}$ & & & $\begin{array}{l}0.164^{\text {*** }} \\
(5.31)\end{array}$ & & $\begin{array}{l}0.163^{* * *} \\
(3.83)\end{array}$ \\
\hline Sdebt $_{\mathrm{t}-1} \times$ Nature & & & $\begin{array}{l}-0.081^{*} \\
(-1.81)\end{array}$ & & & & \\
\hline Nature & & & $\begin{array}{l}0.012 \\
(0.98)\end{array}$ & & & & \\
\hline$Q_{t-1}$ & $\begin{array}{l}0.049^{\text {*** }} \\
(11.13)\end{array}$ & $\begin{array}{l}0.041^{\text {*** }} \\
(9.01)\end{array}$ & $\begin{array}{l}0.049^{* * *} \\
(11.09)\end{array}$ & $\begin{array}{l}0.052^{\text {*** }} \\
(8.92)\end{array}$ & $\begin{array}{l}0.044^{\text {*** }} \\
(7.13)\end{array}$ & $\begin{array}{l}0.041^{\text {*** }} \\
(5.42)\end{array}$ & $\begin{array}{l}0.033^{* * *} \\
(4.30)\end{array}$ \\
\hline Topshare & $\begin{array}{l}-0.043 \\
(-1.43)\end{array}$ & $\begin{array}{l}-0.044 \\
(-1.48)\end{array}$ & $\begin{array}{l}-0.045 \\
(-1.50)\end{array}$ & $\begin{array}{l}0.001 \\
(0.02)\end{array}$ & $\begin{array}{l}0.003 \\
(0.07)\end{array}$ & $\begin{array}{l}-0.087 \\
(-1.44)\end{array}$ & $\begin{array}{l}-0.094 \\
(-1.55)\end{array}$ \\
\hline Director & $\begin{array}{l}0.002 \\
(0.22)\end{array}$ & $\begin{array}{l}0.001 \\
(0.14)\end{array}$ & $\begin{array}{l}0.002 \\
(0.24)\end{array}$ & $\begin{array}{l}0.012 \\
(1.02)\end{array}$ & $\begin{array}{l}0.011 \\
(0.91)\end{array}$ & $\begin{array}{l}-0.011 \\
(-0.73)\end{array}$ & $\begin{array}{l}-0.010 \\
(-0.68)\end{array}$ \\
\hline Indepen & $\begin{array}{l}0.029 \\
(0.66)\end{array}$ & $\begin{array}{l}0.035 \\
(0.79)\end{array}$ & $\begin{array}{l}0.030 \\
(0.68)\end{array}$ & $\begin{array}{l}-0.002 \\
(-0.03)\end{array}$ & $\begin{array}{l}0.003 \\
(0.05)\end{array}$ & $\begin{array}{l}-0.002 \\
(-0.02)\end{array}$ & $\begin{array}{l}0.010 \\
(0.11)\end{array}$ \\
\hline Bsize & $\begin{array}{l}-0.022 \\
(-1.27)\end{array}$ & $\begin{array}{l}-0.021 \\
(-1.20)\end{array}$ & $\begin{array}{l}-0.023 \\
(-1.28)\end{array}$ & $\begin{array}{l}-0.018 \\
(-0.85)\end{array}$ & $\begin{array}{l}-0.015 \\
(-0.72)\end{array}$ & $\begin{array}{l}-0.046 \\
(-1.24)\end{array}$ & $\begin{array}{l}-0.046 \\
(-1.23)\end{array}$ \\
\hline
\end{tabular}


Table 5 (continued)

Total sample $\quad$ SOEs $\quad$ Non-SOEs
(1)
(2)
(3)
(4)
(5)
(6)

(7)

\begin{tabular}{|c|c|c|c|c|c|c|c|}
\hline CEOage & $\begin{array}{l}-0.075^{* * *} \\
(-3.47)\end{array}$ & $\begin{array}{l}-0.071^{* * *} \\
(-3.27)\end{array}$ & $\begin{array}{l}-0.074^{* * *} \\
(-3.42)\end{array}$ & $\begin{array}{l}-0.105^{\text {*** }} \\
(-3.80)\end{array}$ & $\begin{array}{l}-0.098^{* * *} \\
(-3.56)\end{array}$ & $\begin{array}{l}0.039 \\
(0.98)\end{array}$ & $\begin{array}{l}0.039 \\
(0.99)\end{array}$ \\
\hline CEOtenure & $\begin{array}{l}0.000 \\
(0.09)\end{array}$ & $\begin{array}{l}0.000 \\
(0.03)\end{array}$ & $\begin{array}{l}0.000 \\
(0.05)\end{array}$ & $\begin{array}{l}-0.004 \\
(-0.60)\end{array}$ & $\begin{array}{l}-0.005 \\
(-0.74)\end{array}$ & $\begin{array}{l}0.012 \\
(1.21)\end{array}$ & $\begin{array}{l}0.011 \\
(1.16)\end{array}$ \\
\hline CEOShare & $\begin{array}{l}0.911 \\
(1.43)\end{array}$ & $\begin{array}{l}0.929 \\
(1.46)\end{array}$ & $\begin{array}{l}0.892 \\
(1.40)\end{array}$ & $\begin{array}{l}5.772^{* *} \\
(1.96)\end{array}$ & $\begin{array}{l}5.540^{*} \\
(1.89)\end{array}$ & $\begin{array}{l}0.502 \\
(0.72)\end{array}$ & $\begin{array}{l}0.556 \\
(0.80)\end{array}$ \\
\hline $\mathrm{CF}$ & $\begin{array}{l}0.088^{* * *} \\
(10.69)\end{array}$ & $\begin{array}{l}0.089^{* * *} \\
(10.84)\end{array}$ & $\begin{array}{l}0.088^{* * *} \\
(10.69)\end{array}$ & $\begin{array}{l}0.095^{\text {*** }} \\
(8.75)\end{array}$ & $\begin{array}{l}0.095^{\text {*** }} \\
(8.78)\end{array}$ & $\begin{array}{l}0.082^{* * *} \\
(6.08)\end{array}$ & $\begin{array}{l}0.083^{* * *} \\
(6.23)\end{array}$ \\
\hline Sales $\mathrm{t}-1$ & $\begin{array}{l}0.020^{* * *} \\
(11.70)\end{array}$ & $\begin{array}{l}0.020^{* * *} \\
(11.64)\end{array}$ & $\begin{array}{l}0.021^{* * *} \\
(11.73)\end{array}$ & $\begin{array}{l}0.020^{\text {*** }} \\
(8.53)\end{array}$ & $\begin{array}{l}0.019^{* * *} \\
(8.44)\end{array}$ & $\begin{array}{l}0.022^{\text {*** }} \\
(7.09)\end{array}$ & $\begin{array}{l}0.022^{* * *} \\
(7.07)\end{array}$ \\
\hline Roa & $\begin{array}{l}0.148^{\text {*** }} \\
(3.17)\end{array}$ & $\begin{array}{l}0.131^{* * *} \\
(2.80)\end{array}$ & $\begin{array}{l}0.153^{\text {*** }} \\
(3.26)\end{array}$ & $\begin{array}{l}0.150^{* *} \\
(2.43)\end{array}$ & $\begin{array}{l}0.137^{* *} \\
(2.23)\end{array}$ & $\begin{array}{l}0.111 \\
(1.36)\end{array}$ & $\begin{array}{l}0.085 \\
(1.04)\end{array}$ \\
\hline Size & $\begin{array}{l}0.117^{\text {*** }} \\
(20.40)\end{array}$ & $\begin{array}{l}0.120^{* * *} \\
(20.95)\end{array}$ & $\begin{array}{l}0.117^{* * *} \\
(20.34)\end{array}$ & $\begin{array}{l}0.125^{\text {*** }} \\
(17.10)\end{array}$ & $\begin{array}{l}0.128^{* * *} \\
(17.50)\end{array}$ & $\begin{array}{l}0.120^{* * *} \\
(10.81)\end{array}$ & $\begin{array}{l}0.123^{* * *} \\
(11.09)\end{array}$ \\
\hline Market & $\begin{array}{l}-0.011^{*} \\
(-1.67)\end{array}$ & $\begin{array}{l}-0.009 \\
(-1.38)\end{array}$ & $\begin{array}{l}-0.010 \\
(-1.61)\end{array}$ & $\begin{array}{l}0.001 \\
(0.17)\end{array}$ & $\begin{array}{l}0.003 \\
(0.40)\end{array}$ & $\begin{array}{l}-0.033^{* * *} \\
(-2.82)\end{array}$ & $\begin{array}{l}-0.031^{* * *} \\
(-2.69)\end{array}$ \\
\hline Industry dummy & Included & Included & Included & Included & Included & Included & Included \\
\hline Year dummy & Included & Included & Included & Included & Included & Included & Included \\
\hline Adjusted $\mathrm{R}^{2}$ & 0.1259 & 0.1301 & 0.1262 & 0.1173 & 0.1216 & 0.1523 & 0.1569 \\
\hline Observations & 10,451 & 10,451 & 10,451 & 6945 & 6945 & 3506 & 3506 \\
\hline
\end{tabular}

Panel C. Long-term loans. Panel C reports the effect of long-term loans on investment using the firm fixed-effect model. The model specifications are given in Regression 1 and Regression 2. The independent variable is the long-term loan ratio. The sample includes all the observations in our refined data set and the sample period is from 2000 to 2011. t-statistics are in parentheses. *, **, *** denote significance levels of $10 \%, 5 \%$, and $1 \%$, respectively, two-tailed.

\begin{tabular}{|c|c|c|c|c|c|c|c|}
\hline Intercept & $\begin{array}{l}-2.158^{* * *} \\
(-14.03)\end{array}$ & $\begin{array}{l}-2.210^{* * *} \\
(-14.39)\end{array}$ & $\begin{array}{l}-2.154^{* * *} \\
(-13.98)\end{array}$ & $\begin{array}{l}-2.397^{* * *} \\
(-12.25)\end{array}$ & $\begin{array}{l}-2.454^{* * *} \\
(-12.55)\end{array}$ & $\begin{array}{l}-2.228^{\text {*** }} \\
(-7.68)\end{array}$ & $\begin{array}{l}-2.228^{* * *} \\
(-7.70)\end{array}$ \\
\hline Ldebt $_{\mathrm{t}-1}$ & & & & & & $-0.129^{*}$ & $-0.328^{* * *}$ \\
\hline Ldebt $_{\mathrm{t}-1} \times \mathrm{DQ}_{\mathrm{t}-1}$ & $(-5.26)$ & $\begin{array}{l}(-8.17) \\
0.374^{* * *} \\
(7.24)\end{array}$ & $(-4.96)$ & $(-5.30)$ & $\begin{array}{l}(-7.08) \\
0.345^{* * *} \\
(5.40)\end{array}$ & $(-1.84)$ & $\begin{array}{l}(-3.68) \\
0.362^{* * *} \\
(3.61)\end{array}$ \\
\hline Ldebt $_{\mathrm{t}-1} \times$ Nature & & & $\begin{array}{l}0.061 \\
(0.88)\end{array}$ & & & & \\
\hline Nature & & & $\begin{array}{l}-0.009 \\
(-0.95)\end{array}$ & & & & \\
\hline$Q_{t-1}$ & $\begin{array}{l}0.049^{* * *} \\
(11.04)\end{array}$ & $\begin{array}{l}0.042^{* * *} \\
(9.21)\end{array}$ & $\begin{array}{l}0.049^{* * *} \\
(11.04)\end{array}$ & $\begin{array}{l}0.052^{* * *} \\
(8.76)\end{array}$ & $\begin{array}{l}0.045^{\text {*** }} \\
(7.41)\end{array}$ & $\begin{array}{l}0.041^{\text {*** }} \\
(5.30)\end{array}$ & $\begin{array}{l}0.034^{\text {*** }} \\
(4.32)\end{array}$ \\
\hline Topshare & $\begin{array}{l}-0.009 \\
(-0.31)\end{array}$ & $\begin{array}{l}-0.000 \\
(-0.01)\end{array}$ & $\begin{array}{l}-0.011 \\
(-0.38)\end{array}$ & $\begin{array}{l}0.025 \\
(0.65)\end{array}$ & $\begin{array}{l}0.029 \\
(0.74)\end{array}$ & $\begin{array}{l}-0.039 \\
(-0.65)\end{array}$ & $\begin{array}{l}-0.023 \\
(-0.38)\end{array}$ \\
\hline Director & $\begin{array}{l}0.000 \\
(0.03)\end{array}$ & $\begin{array}{l}-0.000 \\
(-0.03)\end{array}$ & $\begin{array}{l}0.000 \\
(0.02)\end{array}$ & $\begin{array}{l}0.010 \\
(0.85)\end{array}$ & $\begin{array}{l}0.010 \\
(0.85)\end{array}$ & $\begin{array}{l}-0.014 \\
(-0.93)\end{array}$ & $\begin{array}{l}-0.014 \\
(-0.92)\end{array}$ \\
\hline Indepen & $\begin{array}{l}0.034 \\
(0.77)\end{array}$ & $\begin{array}{l}0.042 \\
(0.94)\end{array}$ & $\begin{array}{l}0.036 \\
(0.80)\end{array}$ & $\begin{array}{l}0.010 \\
(0.19)\end{array}$ & $\begin{array}{l}0.013 \\
(0.24)\end{array}$ & $\begin{array}{l}0.003 \\
(0.03)\end{array}$ & $\begin{array}{l}0.022 \\
(0.23)\end{array}$ \\
\hline Bsize & $\begin{array}{l}-0.022 \\
(-1.22)\end{array}$ & $\begin{array}{l}-0.021 \\
(-1.17)\end{array}$ & $\begin{array}{l}-0.022 \\
(-1.25)\end{array}$ & $\begin{array}{l}-0.022 \\
(-1.03)\end{array}$ & $\begin{array}{l}-0.020 \\
(-0.93)\end{array}$ & $\begin{array}{l}-0.035 \\
(-0.92)\end{array}$ & $\begin{array}{l}-0.031 \\
(-0.84)\end{array}$ \\
\hline CEOage & $\begin{array}{l}-0.069^{* * *} \\
(-3.16)\end{array}$ & $\begin{array}{l}-0.069^{* * *} \\
(-3.18)\end{array}$ & $\begin{array}{l}-0.069^{* * *} \\
(-3.16)\end{array}$ & $\begin{array}{l}-0.090^{* * *} \\
(-3.27)\end{array}$ & $\begin{array}{l}-0.089^{* * *} \\
(-3.24)\end{array}$ & $\begin{array}{l}0.032 \\
(0.80)\end{array}$ & $\begin{array}{l}0.026 \\
(0.64)\end{array}$ \\
\hline CEOtenure & $\begin{array}{l}0.001 \\
(0.27)\end{array}$ & $\begin{array}{l}0.001 \\
(0.18)\end{array}$ & $\begin{array}{l}0.001 \\
(0.28)\end{array}$ & $\begin{array}{l}-0.004 \\
(-0.57)\end{array}$ & $\begin{array}{l}-0.004 \\
(-0.65)\end{array}$ & $\begin{array}{l}0.014 \\
(1.42)\end{array}$ & $\begin{array}{l}0.012 \\
(1.29)\end{array}$ \\
\hline CEOShare & $\begin{array}{l}0.955 \\
(1.49)\end{array}$ & $\begin{array}{l}0.991 \\
(1.55)\end{array}$ & $\begin{array}{l}0.957 \\
(1.49)\end{array}$ & $\begin{array}{l}6.289^{* *} \\
(2.14)\end{array}$ & $\begin{array}{l}6.470^{* *} \\
(2.20)\end{array}$ & $\begin{array}{l}0.621 \\
(0.88)\end{array}$ & $\begin{array}{l}0.698 \\
(0.99)\end{array}$ \\
\hline $\mathrm{CF}$ & $\begin{array}{l}0.081^{\text {*** }} \\
(9.78)\end{array}$ & $\begin{array}{l}0.081^{* * *} \\
(9.92)\end{array}$ & $\begin{array}{l}0.080^{* * *} \\
(9.77)\end{array}$ & $\begin{array}{l}0.088^{* * *} \\
(8.11)\end{array}$ & $\begin{array}{l}0.089^{\text {*** }} \\
(8.24)\end{array}$ & $\begin{array}{l}0.074^{\text {*** }} \\
(5.47)\end{array}$ & $\begin{array}{l}0.074^{\text {*** }} \\
(5.48)\end{array}$ \\
\hline Sales $t-1$ & $\begin{array}{l}0.021^{\text {*** }} \\
(12.06)\end{array}$ & $\begin{array}{l}0.021^{* * *} \\
(12.00)\end{array}$ & $\begin{array}{l}0.021^{* * *} \\
(12.08)\end{array}$ & $\begin{array}{l}0.020^{* * *} \\
(8.52)\end{array}$ & $\begin{array}{l}0.019^{* * *} \\
(8.39)\end{array}$ & $\begin{array}{l}0.023^{* * *} \\
(7.46)\end{array}$ & $\begin{array}{l}0.023^{* * *} \\
(7.54)\end{array}$ \\
\hline Roa & $\begin{array}{l}0.225^{\text {*** }} \\
(4.85)\end{array}$ & $\begin{array}{l}0.209^{\text {*** }} \\
(4.51)\end{array}$ & $\begin{array}{l}0.226^{\text {*** }} \\
(4.87)\end{array}$ & $\begin{array}{l}0.226^{\text {*** }} \\
(3.74)\end{array}$ & $\begin{array}{l}0.211^{\text {*** }} \\
(3.49)\end{array}$ & $\begin{array}{l}0.145^{*} \\
(1.76)\end{array}$ & $\begin{array}{l}0.129 \\
(1.57)\end{array}$ \\
\hline Size & $\begin{array}{l}0.121^{* * *} \\
(20.47)\end{array}$ & $\begin{array}{l}0.124^{* * *} \\
(20.96)\end{array}$ & $\begin{array}{l}0.121^{* * *} \\
(20.45)\end{array}$ & $\begin{array}{l}0.132^{\text {*** }} \\
(17.43)\end{array}$ & $\begin{array}{l}0.134^{\text {**** }} \\
(17.77)\end{array}$ & $\begin{array}{l}0.121^{\text {*** }} \\
(10.68)\end{array}$ & $\begin{array}{l}0.122^{* * *} \\
(10.81)\end{array}$ \\
\hline Market & $\begin{array}{l}-0.015^{* *} \\
(-2.31)\end{array}$ & $\begin{array}{l}-0.014^{* *} \\
(-2.22)\end{array}$ & $\begin{array}{l}-0.015^{* *} \\
(-2.31)\end{array}$ & $\begin{array}{l}-0.002 \\
(-0.25)\end{array}$ & $\begin{array}{l}-0.000 \\
(-0.03)\end{array}$ & $\begin{array}{l}-0.043^{* * *} \\
(-3.69)\end{array}$ & $\begin{array}{l}-0.044^{* * *} \\
(-3.76)\end{array}$ \\
\hline Industry dummy & Included & Included & Included & Included & Included & Included & Included \\
\hline Year dummy & Included & Included & Included & Included & Included & Included & Included \\
\hline Adjusted $\mathrm{R}^{2}$ & 0.1180 & 0.1232 & 0.1181 & 0.1143 & 0.1187 & 0.1362 & 0.1404 \\
\hline Observations & 10,451 & 10,451 & 10,451 & 6945 & 6945 & 3506 & 3506 \\
\hline
\end{tabular}


Table 6

Regression analysis using sales growth as the proxy for firms' future growth opportunities.

Total sample SOEs

(1)

(2)

(3)

(4)

5)

Non-SOEs

Panel A. Total bank loans. Panel A reports the effect of total bank loans on investment using sales growth as the proxy for firms' future growth opportunities. Two-step least square regressions are applied. In the first step, we run the regression in which the bank loan ratio is predicted by the fixed-assets ratio and the inventory ratio. Then we use the predicted value of the bank loan ratio in the second-stage regressions which are defined in Regression 1 and Regression 2. The sample includes all the observations in our refined data set and the sample period is from 2000 to 2011 . $t$-statistics are in parentheses. $*, * *, * *$ denote significance levels of $10 \%, 5 \%$, and $1 \%$, respectively, two-tailed.

\begin{tabular}{|c|c|c|c|c|c|c|c|}
\hline Intercept & $-0.479^{* * *}$ & $-0.449^{* * *}$ & $-0.523^{* * *}$ & $-0.431^{* * *}$ & $-0.411^{* * *}$ & $-0.551^{\text {*** }}$ & $-0.510^{* * *}$ \\
\hline & $(-6.67)$ & $(-6.22)$ & $(-6.99)$ & $(-4.74)$ & $(-4.51)$ & $(-4.21)$ & $(-3.88)$ \\
\hline \multirow[t]{2}{*}{ Debt $_{t-1}$} & $-0.702^{* * *}$ & $-0.753^{* * *}$ & $-0.589^{* * *}$ & $-0.676^{* * *}$ & $-0.720^{* * *}$ & $-0.801^{* * *}$ & $-0.850^{* * *}$ \\
\hline & $(-10.02)$ & $(-10.66)$ & $(-7.17)$ & $(-7.79)$ & $(-8.22)$ & $(-6.61)$ & $(-6.95)$ \\
\hline \multirow[t]{2}{*}{$\operatorname{Debt}_{\mathrm{t}-1} \times \mathrm{DG}$} & & $0.109^{* * *}$ & & & $0.090^{* * *}$ & & $0.119^{* * *}$ \\
\hline & & (5.11) & & & (3.53) & & $(2.96)$ \\
\hline \multirow[t]{2}{*}{ Debt $_{\mathrm{t}-1} \times$ Nature } & & & $-0.304^{* *}$ & & & & \\
\hline & & & $(-2.53)$ & & & & \\
\hline \multirow[t]{2}{*}{ Nature } & & & $0.076^{* * *}$ & & & & \\
\hline & & & $(2.67)$ & & & & \\
\hline \multirow[t]{2}{*}{ Growth } & $0.090^{* * *}$ & $0.068^{* * *}$ & $0.090^{* * *}$ & $0.114^{* * *}$ & $0.094^{* * *}$ & $0.059^{* * *}$ & $0.038^{* * *}$ \\
\hline & (15.05) & $(9.18)$ & (14.99) & $(14.30)$ & $(9.60)$ & $(6.38)$ & $(3.25)$ \\
\hline \multirow[t]{2}{*}{ Topshare } & -0.008 & -0.007 & -0.005 & $-0.033^{* *}$ & $-0.032^{*}$ & $0.065^{* *}$ & $0.066^{* *}$ \\
\hline & $(-0.60)$ & $(-0.50)$ & $(-0.33)$ & $(-2.02)$ & $(-1.96)$ & $(2.36)$ & $(2.41)$ \\
\hline \multirow[t]{2}{*}{ Director } & 0.008 & 0.008 & 0.007 & 0.000 & 0.000 & 0.011 & 0.011 \\
\hline & $(1.25)$ & (1.29) & (1.15) & $(0.06)$ & $(0.06)$ & $(1.08)$ & (1.15) \\
\hline \multirow[t]{2}{*}{ Indepen } & 0.003 & 0.002 & 0.001 & -0.005 & -0.005 & 0.014 & 0.010 \\
\hline & $(0.08)$ & $(0.06)$ & $(0.02)$ & $(-0.12)$ & $(-0.12)$ & $(0.20)$ & $(0.15)$ \\
\hline \multirow[t]{2}{*}{ Bsize } & $0.018^{*}$ & $0.018^{*}$ & $0.019^{*}$ & 0.012 & 0.012 & 0.024 & 0.024 \\
\hline & (1.73) & (1.73) & (1.79) & $(0.94)$ & $(0.94)$ & (1.13) & (1.14) \\
\hline \multirow[t]{2}{*}{ CEOage } & $-0.046^{* * *}$ & $-0.046^{* * *}$ & $-0.044^{* * *}$ & $-0.060^{* * *}$ & $-0.060^{* *}$ & -0.016 & -0.016 \\
\hline & $(-3.11)$ & $(-3.11)$ & $(-2.91)$ & $(-3.16)$ & $(-3.16)$ & $(-0.63)$ & $(-0.62)$ \\
\hline \multirow[t]{2}{*}{ CEOtenure } & 0.003 & 0.003 & 0.003 & -0.001 & -0.001 & 0.012 & 0.012 \\
\hline & $(0.65)$ & $(0.63)$ & $(0.62)$ & $(-0.23)$ & $(-0.24)$ & $(1.33)$ & $(1.33)$ \\
\hline \multirow[t]{2}{*}{ CEOShare } & $1.291^{* * * *}$ & $1.240^{* * *}$ & $1.240^{* * *}$ & $1.827^{* *}$ & $1.795^{* *}$ & $1.124^{* * *}$ & $1.069^{* * *}$ \\
\hline & $(6.95)$ & $(6.68)$ & $(6.60)$ & $(2.48)$ & $(2.44)$ & $(5.29)$ & $(5.02)$ \\
\hline \multirow[t]{2}{*}{$\mathrm{CF}$} & $0.053^{* * *}$ & $0.053^{* * *}$ & $0.053^{* * *}$ & $0.053^{* * *}$ & $0.054^{\text {*** }}$ & $0.052^{* * *}$ & $0.052^{* * *}$ \\
\hline & $(7.07)$ & $(7.06)$ & $(7.08)$ & $(5.40)$ & $(5.44)$ & $(4.42)$ & $(4.37)$ \\
\hline \multirow[t]{2}{*}{ Sales $\mathrm{t}-1$} & $0.005^{* * *}$ & $0.005^{* * *}$ & $0.005^{* * *}$ & $0.003^{*}$ & $0.002^{*}$ & $0.008^{* * *}$ & $0.008^{* *}$ \\
\hline & $(4.40)$ & $(4.36)$ & $(4.44)$ & $(1.75)$ & $(1.72)$ & (4.17) & $(4.17)$ \\
\hline \multirow[t]{2}{*}{ Roa } & $0.359^{* * *}$ & $0.339^{* * *}$ & $0.355^{* * *}$ & $0.364^{* * *}$ & $0.346^{* * *}$ & $0.308^{* * *}$ & $0.290^{* * *}$ \\
\hline & $(9.27)$ & $(8.72)$ & (9.16) & $(7.42)$ & $(7.03)$ & $(4.79)$ & $(4.49)$ \\
\hline \multirow[t]{2}{*}{ Size } & $0.042^{* * *}$ & $0.041^{* * *}$ & $0.042^{* * *}$ & $0.043^{* * *}$ & $0.043^{* * *}$ & $0.040^{* * * *}$ & $0.038^{* * *}$ \\
\hline & $(17.47)$ & $(16.88)$ & $(17.47)$ & $(14.70)$ & $(14.40)$ & $(9.30)$ & $(8.81)$ \\
\hline \multirow[t]{2}{*}{ Market } & $-0.008^{* *}$ & $-0.008^{* * *}$ & $-0.008^{* * *}$ & $-0.009^{* * *}$ & $-0.009^{* * *}$ & $-0.005^{* * *}$ & $-0.006^{* * *}$ \\
\hline & $(-7.09)$ & $(-7.01)$ & $(-7.18)$ & $(-6.63)$ & $(-6.51)$ & $(-2.94)$ & $(-2.98)$ \\
\hline Industry dummy & Included & Included & Included & Included & Included & Included & Included \\
\hline Year dummy & Included & Included & Included & Included & Included & Included & Included \\
\hline Adjusted $\mathrm{R}^{2}$ & 0.1470 & 0.1491 & 0.1475 & 0.1521 & 0.1535 & 0.1458 & 0.1477 \\
\hline Observations & 10,446 & 10,446 & 10,446 & 6943 & 6943 & 3503 & 3503 \\
\hline
\end{tabular}

Panel B. Short-term loans. Panel B reports the effect of short-term loans on investment using sales growth as the proxy for firms' future growth opportunities. Two-step least square regressions are applied. In the first step, we run the regression in which the short-term loan ratio is predicted by the inventory ratio. Then we use the predicted value of the short-term loan ratio in the second-stage regressions which are defined in Regression 1 and Regression 2 . The sample includes all the observations in our refined data set and the sample period is from 2000 to 2011 . t-statistics are in parentheses. *,**,*** denote significance levels of $10 \%, 5 \%$, and $1 \%$, respectively, two-tailed.

\begin{tabular}{|c|c|c|c|c|c|c|c|}
\hline Intercept & $\begin{array}{l}0.159 \\
(1.23)\end{array}$ & $\begin{array}{l}0.194 \\
(1.50)\end{array}$ & $\begin{array}{l}0.145 \\
(0.96)\end{array}$ & $\begin{array}{l}0.127 \\
(0.76)\end{array}$ & $\begin{array}{l}0.152 \\
(0.91)\end{array}$ & $\begin{array}{l}0.142 \\
(0.66)\end{array}$ & $\begin{array}{l}0.187 \\
(0.87)\end{array}$ \\
\hline Sdebt $_{\mathrm{t}-1}$ & $\begin{array}{l}-3.665^{\text {*** }} \\
(-6.43)\end{array}$ & $\begin{array}{l}-3.772^{\text {*** }} \\
(-6.62)\end{array}$ & $\begin{array}{l}-3.226^{* * *} \\
(-5.42)\end{array}$ & $\begin{array}{l}-3.278^{\text {*** }} \\
(-4.47)\end{array}$ & $\begin{array}{l}-3.370^{* * *} \\
(-4.59)\end{array}$ & $\begin{array}{l}-4.133^{\text {*** }} \\
(-4.39)\end{array}$ & $\begin{array}{l}-4.241^{* * *} \\
(-4.50)\end{array}$ \\
\hline Sdebt $_{\mathrm{t}-1} \times \mathrm{DG}$ & & $\begin{array}{l}0.125^{* * *} \\
(4.65)\end{array}$ & & & $\begin{array}{l}0.102^{* * *} \\
(3.15)\end{array}$ & & $\begin{array}{l}0.139^{* * *} \\
(2.83)\end{array}$ \\
\hline Sdebt $_{\mathrm{t}-1} \times$ Nature & & & $\begin{array}{l}-0.688^{* *} \\
(-2.20)\end{array}$ & & & & \\
\hline Nature & & & $\begin{array}{l}-0.030 \\
(-0.16)\end{array}$ & & & & \\
\hline Growth & $\begin{array}{l}0.089^{\text {*** }} \\
(14.78)\end{array}$ & $\begin{array}{l}0.068^{* * *} \\
(9.06)\end{array}$ & $\begin{array}{l}0.088^{* * *} \\
(14.67)\end{array}$ & $\begin{array}{l}0.112^{\text {*** }} \\
(13.97)\end{array}$ & $\begin{array}{l}0.093^{\text {*** }} \\
(9.39)\end{array}$ & $\begin{array}{l}0.059^{\text {*** }} \\
(6.33)\end{array}$ & $\begin{array}{l}0.038^{* * *} \\
(3.23)\end{array}$ \\
\hline Topshare & $\begin{array}{l}-0.010 \\
(-0.70)\end{array}$ & $\begin{array}{l}-0.008 \\
(-0.58)\end{array}$ & $\begin{array}{l}-0.005 \\
(-0.39)\end{array}$ & $\begin{array}{l}-0.033^{* *} \\
(-2.00)\end{array}$ & $\begin{array}{l}-0.032^{*} \\
(-1.93)\end{array}$ & $\begin{array}{l}0.066^{* *} \\
(2.40)\end{array}$ & $\begin{array}{l}0.068^{* *} \\
(2.48)\end{array}$ \\
\hline Director & $\begin{array}{l}0.009 \\
(1.43)\end{array}$ & $\begin{array}{l}0.009 \\
(1.45)\end{array}$ & $\begin{array}{l}0.008 \\
(1.36)\end{array}$ & $\begin{array}{l}0.001 \\
(0.17)\end{array}$ & $\begin{array}{l}0.001 \\
(0.16)\end{array}$ & $\begin{array}{l}0.012 \\
(1.20)\end{array}$ & $\begin{array}{l}0.012 \\
(1.24)\end{array}$ \\
\hline
\end{tabular}


Table 6 (continued)

Total sample

(1)

(2)

(3)
Non-SOES

(6)

Panel B. Short-term loans. Panel B reports the effect of short-term loans on investment using sales growth as the proxy for firms' future growth opportunities. Two-step least square regressions are applied. In the first step, we run the regression in which the short-term loan ratio is predicted by the inventory ratio. Then we use the predicted value of the short-term loan ratio in the second-stage regressions which are defined in Regression 1 and Regression 2 . The sample includes all the observations in our refined data set and the sample period is from 2000 to 2011 . t-statistics are in parentheses. *, **, *** denote significance levels of $10 \%, 5 \%$, and $1 \%$, respectively, two-tailed.

\begin{tabular}{|c|c|c|c|c|c|c|c|}
\hline Indepen & $\begin{array}{l}0.004 \\
(0.10)\end{array}$ & $\begin{array}{l}0.003 \\
(0.09)\end{array}$ & $\begin{array}{l}0.003 \\
(0.08)\end{array}$ & $\begin{array}{l}-0.008 \\
(-0.18)\end{array}$ & $\begin{array}{l}-0.007 \\
(-0.17)\end{array}$ & $\begin{array}{l}0.020 \\
(0.29)\end{array}$ & $\begin{array}{l}0.017 \\
(0.25)\end{array}$ \\
\hline Bsize & 0.015 & 0.015 & 0.017 & 0.009 & 0.009 & 0.023 & 0.023 \\
\hline & $(1.43)$ & $(1.44)$ & (1.59) & $(0.72)$ & $(0.72)$ & $(1.07)$ & (1.09) \\
\hline CEOage & $\begin{array}{l}-0.050^{* * *} \\
(-3.37)\end{array}$ & $\begin{array}{l}-0.050^{* * *} \\
(-3.36)\end{array}$ & $\begin{array}{l}-0.048^{* * *} \\
(-3.15)\end{array}$ & $\begin{array}{l}-0.061^{\text {*** }} \\
(-3.24)\end{array}$ & $\begin{array}{l}-0.061^{* * *} \\
(-3.24)\end{array}$ & $\begin{array}{l}-0.021 \\
(-0.83)\end{array}$ & $\begin{array}{l}-0.021 \\
(-0.82)\end{array}$ \\
\hline CEOtenure & $\begin{array}{l}0.003 \\
(0.55)\end{array}$ & $\begin{array}{l}0.003 \\
(0.53)\end{array}$ & $\begin{array}{l}0.003 \\
(0.55)\end{array}$ & $\begin{array}{l}-0.002 \\
(-0.39)\end{array}$ & $\begin{array}{l}-0.002 \\
(-0.40)\end{array}$ & $\begin{array}{l}0.012 \\
(1.37)\end{array}$ & $\begin{array}{l}0.012 \\
(1.36)\end{array}$ \\
\hline CEOShare & $\begin{array}{l}1.314^{* * *} \\
(7.06)\end{array}$ & $\begin{array}{l}1.265^{* * *} \\
(6.79)\end{array}$ & $\begin{array}{l}1.273^{* * *} \\
(6.76)\end{array}$ & $\begin{array}{l}2.039^{* * *} \\
(2.76)\end{array}$ & $\begin{array}{l}1.996^{* * *} \\
(2.70)\end{array}$ & $\begin{array}{l}1.145^{* * *} \\
(5.37)\end{array}$ & $\begin{array}{l}1.093^{* * *} \\
(5.11)\end{array}$ \\
\hline $\mathrm{CF}$ & $\begin{array}{l}0.058^{\text {*** }} \\
(7.66)\end{array}$ & $\begin{array}{l}0.057^{\text {*** }} \\
(7.62)\end{array}$ & $\begin{array}{l}0.058^{\text {*** }} \\
(7.69)\end{array}$ & $\begin{array}{l}0.058^{* * *} \\
(5.90)\end{array}$ & $\begin{array}{l}0.058^{\text {*** }} \\
(5.91)\end{array}$ & $\begin{array}{l}0.056^{\text {*** }} \\
(4.76)\end{array}$ & $\begin{array}{l}0.056^{* * *} \\
(4.69)\end{array}$ \\
\hline Sales ${ }_{t-1}$ & $\begin{array}{l}0.012^{* * *} \\
(10.94)\end{array}$ & $\begin{array}{l}0.012^{* * *} \\
(10.86)\end{array}$ & $\begin{array}{l}0.012^{* * *} \\
(10.92)\end{array}$ & $\begin{array}{l}0.009^{* * *} \\
(6.75)\end{array}$ & $\begin{array}{l}0.009^{* * *} \\
(6.69)\end{array}$ & $\begin{array}{l}0.015^{* * *} \\
(8.37)\end{array}$ & $\begin{array}{l}0.015^{* * *} \\
(8.34)\end{array}$ \\
\hline Roa & $\begin{array}{l}0.339^{* * *} \\
(8.73)\end{array}$ & $\begin{array}{l}0.319^{* * *} \\
(8.17)\end{array}$ & $\begin{array}{l}0.336^{* * *} \\
(8.65)\end{array}$ & $\begin{array}{l}0.342^{* * *} \\
(6.95)\end{array}$ & $\begin{array}{l}0.325^{\text {*** }} \\
(6.57)\end{array}$ & $\begin{array}{l}0.292^{* * *} \\
(4.51)\end{array}$ & $\begin{array}{l}0.272^{* * *} \\
(4.19)\end{array}$ \\
\hline Size & $\begin{array}{l}0.038^{* * *} \\
(16.17)\end{array}$ & $\begin{array}{l}0.037^{* * *} \\
(15.65)\end{array}$ & $\begin{array}{l}0.039^{* * *} \\
(16.21)\end{array}$ & $\begin{array}{l}0.040^{* * *} \\
(13.64)\end{array}$ & $\begin{array}{l}0.039^{* * *} \\
(13.39)\end{array}$ & $\begin{array}{l}0.037^{* * *} \\
(8.60)\end{array}$ & $\begin{array}{l}0.035^{\text {*** }} \\
(8.17)\end{array}$ \\
\hline Market & $\begin{array}{l}-0.008^{* * *} \\
(-7.16)\end{array}$ & $\begin{array}{l}-0.008^{* * *} \\
(-7.09)\end{array}$ & $\begin{array}{l}-0.008^{* * *} \\
(-7.24)\end{array}$ & $\begin{array}{l}-0.009^{* * *} \\
(-6.77)\end{array}$ & $\begin{array}{l}-0.009^{* * *} \\
(-6.66)\end{array}$ & $\begin{array}{l}-0.006^{* * *} \\
(-3.02)\end{array}$ & $\begin{array}{l}-0.006^{* * *} \\
(-3.07)\end{array}$ \\
\hline Industry dummy & Included & Included & Included & Included & Included & Included & Included \\
\hline Year dummy & Included & Included & Included & Included & Included & Included & Included \\
\hline Adjusted $\mathrm{R}^{2}$ & 0.1422 & 0.1439 & 0.1426 & 0.1471 & 0.1482 & 0.1398 & 0.1415 \\
\hline Observations & 10,446 & 10,446 & 10,446 & 6943 & 6943 & 3503 & 3503 \\
\hline
\end{tabular}

Panel C. Long-term Loans. Panel C reports the effect of long-term loans on investment using sales growth as the proxy for firms' future growth opportunities. Two-step least square regressions are applied. In the first step, we run the regression in which the long-term loan ratio is predicted by the fixed-assets ratio. Then we use the predicted value of the long-term loan ratio in the second-stage regressions which are defined in Regression 1 and Regression 2 . The sample includes all the observations in our refined data set and the sample period is from 2000 to 2011 . t-statistics are in parentheses. ${ }^{*},{ }^{* *},{ }^{* * *}$ denote significance levels of $10 \%, 5 \%$, and $1 \%$, respectively, two-tailed.

\begin{tabular}{|c|c|c|c|c|c|c|c|}
\hline Intercept & $-0.545^{* * *}$ & $-0.509^{* * *}$ & $-0.573^{* * *}$ & $-0.513^{\text {*** }}$ & $-0.486^{\text {*** }}$ & $-0.602^{\text {*** }}$ & $-0.562^{* * *}$ \\
\hline Ldebt $_{\mathrm{t}-1}$ & $\begin{array}{l}(-7.56) \\
-0.570^{* * *} \\
(-4.54)\end{array}$ & $\begin{array}{l}(-7.05) \\
-0.871^{* * *} \\
(-6.51)\end{array}$ & $\begin{array}{l}(-7.71) \\
-0.632^{* * *} \\
(-3.05)\end{array}$ & $\begin{array}{l}(-5.65) \\
-0.629^{* * *} \\
(-4.03)\end{array}$ & $\begin{array}{l}(-5.35) \\
-0.863^{* * *} \\
(-5.22)\end{array}$ & $\begin{array}{l}(-4.59) \\
-0.587^{\text {*** }} \\
(-2.72)\end{array}$ & $\begin{array}{l}(-4.27) \\
-0.938^{* * *} \\
(-4.02)\end{array}$ \\
\hline Ldebt $_{\mathrm{t}-1} \times \mathrm{DG}$ & & $\begin{array}{l}0.641^{* * *} \\
(6.38)\end{array}$ & & & $\begin{array}{l}0.500^{* * *} \\
(4.27)\end{array}$ & & $\begin{array}{l}0.773^{* * *} \\
(3.89)\end{array}$ \\
\hline Ldebt $_{\mathrm{t}-1} \times$ Nature & & & $\begin{array}{l}0.091 \\
(1.01)\end{array}$ & & & & \\
\hline Nature & & & $\begin{array}{l}0.022^{* *} \\
(2.44)\end{array}$ & & & & \\
\hline Growth & $\begin{array}{l}0.088^{* * *} \\
(14.64)\end{array}$ & $\begin{array}{l}0.066^{* * *} \\
(9.61)\end{array}$ & $\begin{array}{l}0.088^{* * *} \\
(14.54)\end{array}$ & $\begin{array}{l}0.112^{* * *} \\
(13.99)\end{array}$ & $\begin{array}{l}0.092^{* * *} \\
(9.98)\end{array}$ & $\begin{array}{l}0.057^{* * *} \\
(6.09)\end{array}$ & $\begin{array}{l}0.036^{* * *} \\
(3.34)\end{array}$ \\
\hline Topshare & $\begin{array}{l}-0.010 \\
(-0.76)\end{array}$ & $\begin{array}{l}-0.009 \\
(-0.71)\end{array}$ & $\begin{array}{l}-0.007 \\
(-0.48)\end{array}$ & $\begin{array}{l}-0.032^{*} \\
(-1.96)\end{array}$ & $\begin{array}{l}-0.032^{*} \\
(-1.92)\end{array}$ & $\begin{array}{l}0.060^{* *} \\
(2.18)\end{array}$ & $\begin{array}{l}0.060^{* *} \\
(2.18)\end{array}$ \\
\hline Director & $\begin{array}{l}0.007 \\
(1.21)\end{array}$ & $\begin{array}{l}0.008 \\
(1.34)\end{array}$ & $\begin{array}{l}0.007 \\
(1.13)\end{array}$ & $\begin{array}{l}-0.001 \\
(-0.16)\end{array}$ & $\begin{array}{l}-0.001 \\
(-0.10)\end{array}$ & $\begin{array}{l}0.012 \\
(1.26)\end{array}$ & $\begin{array}{l}0.014 \\
(1.41)\end{array}$ \\
\hline Indepen & $\begin{array}{l}0.002 \\
(0.05)\end{array}$ & $\begin{array}{l}-0.000 \\
(-0.00)\end{array}$ & $\begin{array}{l}0.001 \\
(0.03)\end{array}$ & $\begin{array}{l}-0.010 \\
(-0.24)\end{array}$ & $\begin{array}{l}-0.011 \\
(-0.26)\end{array}$ & $\begin{array}{l}0.022 \\
(0.32)\end{array}$ & $\begin{array}{l}0.018 \\
(0.27)\end{array}$ \\
\hline Bsize & $\begin{array}{l}0.016 \\
(1.52)\end{array}$ & $\begin{array}{l}0.016 \\
(1.50)\end{array}$ & $\begin{array}{l}0.018^{*} \\
(1.65)\end{array}$ & $\begin{array}{l}0.009 \\
(0.77)\end{array}$ & $\begin{array}{l}0.009 \\
(0.76)\end{array}$ & $\begin{array}{l}0.023 \\
(1.12)\end{array}$ & $\begin{array}{l}0.024 \\
(1.16)\end{array}$ \\
\hline CEOage & $\begin{array}{l}-0.049^{* * *} \\
(-3.29)\end{array}$ & $\begin{array}{l}-0.050^{* * *} \\
(-3.33)\end{array}$ & $\begin{array}{l}-0.046^{\text {*** }} \\
(-3.07)\end{array}$ & $\begin{array}{l}-0.061^{* * *} \\
(-3.21)\end{array}$ & $\begin{array}{l}-0.062^{* * *} \\
(-3.26)\end{array}$ & $\begin{array}{l}-0.021 \\
(-0.81)\end{array}$ & $\begin{array}{l}-0.020 \\
(-0.78)\end{array}$ \\
\hline CEOtenure & $\begin{array}{l}0.002 \\
(0.47)\end{array}$ & $\begin{array}{l}0.002 \\
(0.47)\end{array}$ & $\begin{array}{l}0.002 \\
(0.45)\end{array}$ & $\begin{array}{l}-0.002 \\
(-0.41)\end{array}$ & $\begin{array}{l}-0.002 \\
(-0.41)\end{array}$ & $\begin{array}{l}0.012 \\
(1.30)\end{array}$ & $\begin{array}{l}0.012 \\
(1.33)\end{array}$ \\
\hline CEOShare & $\begin{array}{l}1.329^{\text {*** }} \\
(7.13)\end{array}$ & $\begin{array}{l}1.274^{* * *} \\
(6.84)\end{array}$ & $\begin{array}{l}1.268^{* * *} \\
(6.72)\end{array}$ & $\begin{array}{l}2.155^{* * *} \\
(2.92)\end{array}$ & $\begin{array}{l}2.119^{* * *} \\
(2.88)\end{array}$ & $\begin{array}{l}1.115^{\text {*** }} \\
(5.22)\end{array}$ & $\begin{array}{l}1.056^{* * *} \\
(4.94)\end{array}$ \\
\hline $\mathrm{CF}$ & $\begin{array}{l}0.057^{\text {*** }} \\
(7.59)\end{array}$ & $\begin{array}{l}0.058^{* * *} \\
(7.64)\end{array}$ & $\begin{array}{l}0.058^{* * *} \\
(7.62)\end{array}$ & $\begin{array}{l}0.057^{\text {*** }} \\
(5.77)\end{array}$ & $\begin{array}{l}0.058^{\text {*** }} \\
(5.87)\end{array}$ & $\begin{array}{l}0.056^{\text {*** }} \\
(4.73)\end{array}$ & $\begin{array}{l}0.057^{* * *} \\
(4.69)\end{array}$ \\
\hline Sales $t-1$ & $\begin{array}{l}0.007^{\text {*** }} \\
(5.53)\end{array}$ & $\begin{array}{l}0.007^{\text {*** }} \\
(5.70)\end{array}$ & $\begin{array}{l}0.007^{* * *} \\
(5.54)\end{array}$ & $\begin{array}{l}0.004^{* *} \\
(2.44)\end{array}$ & $\begin{array}{l}0.004^{* *} \\
(2.57)\end{array}$ & $\begin{array}{l}0.010^{\text {*** }} \\
(5.06)\end{array}$ & $\begin{array}{l}0.011^{\text {*** }} \\
(5.18)\end{array}$ \\
\hline Roa & $\begin{array}{l}0.359^{\text {*** }} \\
(9.23)\end{array}$ & $\begin{array}{l}0.338^{* * *} \\
(8.66)\end{array}$ & $\begin{array}{l}0.355^{\text {*** }} \\
(9.11)\end{array}$ & $\begin{array}{l}0.361^{\text {*** }} \\
(7.34)\end{array}$ & $\begin{array}{l}0.344^{\text {*** }} \\
(6.97)\end{array}$ & $\begin{array}{l}0.317^{\text {*** }} \\
(4.89)\end{array}$ & $\begin{array}{l}0.295^{\text {*** }} \\
(4.55)\end{array}$ \\
\hline
\end{tabular}


Table 6 (continued)

Total sample

(1)

(2)

(3)

SOE

(4)
Non-SOES

(6)

(7)

Table 7

Regression analysis comparing the disciplining roles between short-term and long-term loans. This table compares the disciplining roles between short-term and long-term loans. We use the ordinary least square regression (OLS), the instrumental variable approach (IV), and the firm fixed-effect model (FEM), respectively. In Columns (1)-(3), we use Tobin's Q as the proxy for firms' future growth. In Columns (4)-(6), we use sales growth as the proxy for firms' future growth. The regression model is defined in Regression 3. The sample includes all the observations in our refined data set and the sample period is from 2000 to 2011. t-statistics are in parentheses. *, **, ${ }^{* * *}$ denote significance levels of $10 \%, 5 \%$, and $1 \%$, respectively, two-tailed.

\begin{tabular}{|c|c|c|c|c|c|c|}
\hline & OLS & IV & FEM & OLS & IV & FEM \\
\hline & (1) & (2) & (3) & $(4)$ & (5) & (6) \\
\hline Intercept & $\begin{array}{l}-0.739^{* * *} \\
(-9.08)\end{array}$ & $\begin{array}{l}-0.557^{\text {*** }} \\
(-6.67)\end{array}$ & $\begin{array}{l}-2.262^{\text {*** }} \\
(-14.28)\end{array}$ & $\begin{array}{l}-0.496^{* * *} \\
(-6.55)\end{array}$ & $\begin{array}{l}-0.352^{\text {*** }} \\
(-4.55)\end{array}$ & $\begin{array}{l}-1.747^{\text {*** }} \\
(-11.18)\end{array}$ \\
\hline Debt $_{t-1}$ & $\begin{array}{l}-0.102^{* * *} \\
(-5.10)\end{array}$ & $\begin{array}{l}-1.219^{* * *} \\
(-8.48)\end{array}$ & $\begin{array}{l}-0.333^{* * *} \\
(-11.29)\end{array}$ & $\begin{array}{l}-0.119^{* * *} \\
(-5.99)\end{array}$ & $\begin{array}{l}-1.341^{\text {*** }} \\
(-9.42)\end{array}$ & $\begin{array}{l}-0.341^{* * *} \\
(-11.52)\end{array}$ \\
\hline $\operatorname{Debt}_{\mathrm{t}-1} \times \mathrm{DM}_{\mathrm{t}-1}$ & $\begin{array}{l}0.236^{* * *} \\
(4.50)\end{array}$ & $\begin{array}{l}3.015^{* * *} \\
(3.93)\end{array}$ & $\begin{array}{l}0.093^{* * *} \\
(3.39)\end{array}$ & $\begin{array}{l}0.195^{* * *} \\
(3.75)\end{array}$ & $\begin{array}{l}3.059^{* * *} \\
(4.02)\end{array}$ & $\begin{array}{l}0.038^{* * *} \\
(3.57)\end{array}$ \\
\hline $\mathrm{DM}_{\mathrm{t}-1}$ & $\begin{array}{l}-0.029^{* *} \\
(-2.00)\end{array}$ & $\begin{array}{l}-0.615^{* * *} \\
(-3.18)\end{array}$ & $\begin{array}{l}-0.024 \\
(-1.36)\end{array}$ & $\begin{array}{l}-0.023 \\
(-1.62)\end{array}$ & $\begin{array}{l}-0.580^{* * *} \\
(-3.02)\end{array}$ & $\begin{array}{l}-0.016 \\
(-0.91)\end{array}$ \\
\hline $\mathrm{Q}_{\mathrm{t}-1}$ & $\begin{array}{l}0.037^{* * *} \\
(9.42)\end{array}$ & $\begin{array}{l}0.028^{* * *} \\
(7.61)\end{array}$ & $\begin{array}{l}0.053^{* * *} \\
(11.28)\end{array}$ & & & \\
\hline Growth & & & & $\begin{array}{l}0.088^{* * * *} \\
(14.25)\end{array}$ & $\begin{array}{l}0.091^{\text {*** }} \\
(15.10)\end{array}$ & $\begin{array}{l}0.054^{* * *} \\
(7.81)\end{array}$ \\
\hline Topshare & $\begin{array}{l}0.000 \\
(0.02)\end{array}$ & $\begin{array}{l}0.003 \\
(0.22)\end{array}$ & $\begin{array}{l}-0.053^{*} \\
(-1.73)\end{array}$ & $\begin{array}{l}-0.018 \\
(-1.25)\end{array}$ & $\begin{array}{l}-0.008 \\
(-0.60)\end{array}$ & $\begin{array}{l}-0.080^{* * *} \\
(-2.60)\end{array}$ \\
\hline Director & $\begin{array}{l}0.011^{*} \\
(1.68)\end{array}$ & $\begin{array}{l}0.009 \\
(1.39)\end{array}$ & $\begin{array}{l}0.006 \\
(0.66)\end{array}$ & $\begin{array}{l}0.010 \\
(1.60)\end{array}$ & $\begin{array}{l}0.008 \\
(1.31)\end{array}$ & $\begin{array}{l}0.004 \\
(0.42)\end{array}$ \\
\hline Indepen & $\begin{array}{l}0.018 \\
(0.49)\end{array}$ & $\begin{array}{l}0.019 \\
(0.54)\end{array}$ & $\begin{array}{l}0.034 \\
(0.74)\end{array}$ & $\begin{array}{l}0.004 \\
(0.09)\end{array}$ & $\begin{array}{l}0.004 \\
(0.12)\end{array}$ & $\begin{array}{l}0.021 \\
(0.46)\end{array}$ \\
\hline Bsize & $\begin{array}{l}0.012 \\
(1.13)\end{array}$ & $\begin{array}{l}0.016 \\
(1.46)\end{array}$ & $\begin{array}{l}-0.022 \\
(-1.20)\end{array}$ & $\begin{array}{l}0.014 \\
(1.24)\end{array}$ & $\begin{array}{l}0.018^{*} \\
(1.66)\end{array}$ & $\begin{array}{l}-0.013 \\
(-0.71)\end{array}$ \\
\hline CEOage & $\begin{array}{l}-0.069^{\text {*** }} \\
(-4.48)\end{array}$ & $\begin{array}{l}-0.062^{* * *} \\
(-4.15)\end{array}$ & $\begin{array}{l}-0.074^{* * *} \\
(-3.32)\end{array}$ & $\begin{array}{l}-0.055^{* * *} \\
(-3.62)\end{array}$ & $\begin{array}{l}-0.047^{\text {*** }} \\
(-3.18)\end{array}$ & $\begin{array}{l}-0.064^{* * *} \\
(-2.87)\end{array}$ \\
\hline CEOtenure & $\begin{array}{l}-0.001 \\
(-0.15)\end{array}$ & $\begin{array}{l}0.002 \\
(0.35)\end{array}$ & $\begin{array}{l}0.002 \\
(0.29)\end{array}$ & $\begin{array}{l}0.000 \\
(0.09)\end{array}$ & $\begin{array}{l}0.004 \\
(0.73)\end{array}$ & $\begin{array}{l}0.001 \\
(0.18)\end{array}$ \\
\hline CEOShare & $\begin{array}{l}1.341^{* * *} \\
(6.78)\end{array}$ & $\begin{array}{l}1.314^{* * *} \\
(7.02)\end{array}$ & $\begin{array}{l}0.755 \\
(1.15)\end{array}$ & $\begin{array}{l}1.298^{* * *} \\
(6.60)\end{array}$ & $\begin{array}{l}1.274^{\text {*** }} \\
(6.87)\end{array}$ & $\begin{array}{l}0.598 \\
(0.90)\end{array}$ \\
\hline $\mathrm{CF}$ & $\begin{array}{l}0.066^{* * *} \\
(8.35)\end{array}$ & $\begin{array}{l}0.055^{* * *} \\
(7.31)\end{array}$ & $\begin{array}{l}0.094^{* * *} \\
(10.99)\end{array}$ & $\begin{array}{l}0.062^{* * *} \\
(7.89)\end{array}$ & $\begin{array}{l}0.052^{\text {*** }} \\
(6.91)\end{array}$ & $\begin{array}{l}0.089^{* * *} \\
(10.31)\end{array}$ \\
\hline Sales t-1 & $\begin{array}{l}0.011^{* * *} \\
(9.82)\end{array}$ & $\begin{array}{l}0.007^{* * *} \\
(5.46)\end{array}$ & $\begin{array}{l}0.018^{\text {*** }} \\
(9.66)\end{array}$ & $\begin{array}{l}0.009^{* * *} \\
(8.20)\end{array}$ & $\begin{array}{l}0.006^{* *} \\
(4.59)\end{array}$ & $\begin{array}{l}0.017^{\text {*** }} \\
(9.22)\end{array}$ \\
\hline Roa & $\begin{array}{l}0.366^{\text {*** }} \\
(8.83)\end{array}$ & $\begin{array}{l}0.424^{* * *} \\
(10.86)\end{array}$ & $\begin{array}{l}0.145^{\text {*** }} \\
(3.03)\end{array}$ & $\begin{array}{l}0.300^{* * *} \\
(7.21)\end{array}$ & $\begin{array}{l}0.357^{\text {*** }} \\
(9.21)\end{array}$ & $\begin{array}{l}0.138^{\text {*** }} \\
(2.82)\end{array}$ \\
\hline Size & $\begin{array}{l}0.049^{* * *} \\
(17.69)\end{array}$ & $\begin{array}{l}0.052^{* * *} \\
(19.91)\end{array}$ & $\begin{array}{l}0.130^{* * * *} \\
(21.08)\end{array}$ & $\begin{array}{l}0.038^{* * *} \\
(14.72)\end{array}$ & $\begin{array}{l}0.042^{* * * *} \\
(17.56)\end{array}$ & $\begin{array}{l}0.108^{* * *} \\
(17.57)\end{array}$ \\
\hline Market & $\begin{array}{l}-0.008^{* * *} \\
(-7.26)\end{array}$ & $\begin{array}{l}-0.009^{* * *} \\
(-7.95)\end{array}$ & $\begin{array}{l}-0.009 \\
(-1.43)\end{array}$ & $\begin{array}{l}-0.007^{* * *} \\
(-6.46)\end{array}$ & $\begin{array}{l}-0.008^{* * *} \\
(-7.09)\end{array}$ & $\begin{array}{l}-0.011 \\
(-1.63)\end{array}$ \\
\hline Industry dummy & Included & Included & Included & Included & Included & Included \\
\hline Year dummy & Included & Included & Included & Included & Included & Included \\
\hline Adjusted $\mathrm{R}^{2}$ & 0.1334 & 0.1354 & 0.1360 & 0.1433 & 0.1492 & 0.1494 \\
\hline Observations & 9814 & 9814 & 9814 & 9810 & 9810 & 9810 \\
\hline
\end{tabular}


Table 8

The effect of China's banking reform in 2003. This table reports the effect of China's banking reform in 2003 on the relation between bank loans and investment. Period03 is a dummy variable which is equal to 1 if the observation year is after 2003 and 0 otherwise. The sample includes all the observations in our refined data set and the sample period is from 2000 to 2011 . t-statistics are in parentheses. ${ }^{*},{ }^{* *}$, ${ }^{* * *}$ denote significance levels of $10 \%, 5 \%$, and $1 \%$, respectively, two-tailed.

\begin{tabular}{|c|c|c|c|c|c|c|c|c|c|}
\hline & \multicolumn{3}{|l|}{ Total sample } & \multicolumn{3}{|l|}{ SOEs } & \multicolumn{3}{|l|}{ Non-SOEs } \\
\hline & $(1)$ & $(2)$ & $(3)$ & $(4)$ & $(5)$ & (6) & $(7)$ & $(8)$ & (9) \\
\hline $\begin{array}{l}\text { Intercept } \\
\text { Debt }_{\mathrm{t}-1}\end{array}$ & $\begin{array}{l}-0.421^{\text {*** }} \\
(-5.45) \\
-0.954^{* * *} \\
(-7.37)\end{array}$ & $\begin{array}{l}0.168 \\
(0.69)\end{array}$ & $\begin{array}{l}-0.529^{* * *} \\
(-7.23)\end{array}$ & $\begin{array}{l}-0.407^{\text {*** }} \\
(-4.21) \\
-0.896^{* * *} \\
(-6.08)\end{array}$ & $\begin{array}{l}0.082 \\
(0.29)\end{array}$ & $\begin{array}{l}-0.525^{* * *} \\
(-5.69)\end{array}$ & $\begin{array}{l}-0.485^{\text {*** }} \\
(-3.42) \\
-1.113^{* * *} \\
(-4.06)\end{array}$ & $\begin{array}{l}0.292 \\
(0.62)\end{array}$ & $\begin{array}{l}-0.586^{* * *} \\
(-4.45)\end{array}$ \\
\hline Debt $_{\mathrm{t}-1} \times$ Period03 & $\begin{array}{l}0.351^{* *} \\
(2.48)\end{array}$ & & & $\begin{array}{l}0.362^{* *} \\
(2.20)\end{array}$ & & & $\begin{array}{l}0.346 \\
(1.19)\end{array}$ & & \\
\hline Sebt $t_{t-1}$ & & $\begin{array}{l}-3.770^{* * *} \\
(-3.11)\end{array}$ & & & $\begin{array}{l}-3.258^{* *} \\
(-2.30)\end{array}$ & & & $\begin{array}{l}-4.955^{* *} \\
(-2.07)\end{array}$ & \\
\hline Sebt $_{\mathrm{t}-1} \times$ Period03 & & $\begin{array}{l}0.206 \\
(0.16)\end{array}$ & & & $\begin{array}{l}-0.001 \\
(-0.00)\end{array}$ & & & $\begin{array}{l}0.844 \\
(0.34)\end{array}$ & \\
\hline Ldebt $_{t-1}$ & & & $\begin{array}{l}-1.078^{\text {*** }} \\
(-4.78)\end{array}$ & & & $\begin{array}{l}-1.061^{* * *} \\
(-4.13)\end{array}$ & & & $\begin{array}{l}-1.174^{* *} \\
(-2.41)\end{array}$ \\
\hline Ldebt $_{\mathrm{t}-1} \times$ Period03 & & & $\begin{array}{l}0.650^{* * *} \\
(2.77)\end{array}$ & & & $\begin{array}{l}0.645^{* *} \\
(2.42)\end{array}$ & & & $\begin{array}{l}0.647 \\
(1.28)\end{array}$ \\
\hline Period03 & $\begin{array}{l}-0.111^{\text {*** }} \\
(-3.32)\end{array}$ & $\begin{array}{l}-0.073 \\
(-0.30)\end{array}$ & $\begin{array}{l}-0.061^{\text {*** }} \\
(-5.35)\end{array}$ & $\begin{array}{l}-0.106^{\text {*** }} \\
(-2.70)\end{array}$ & $\begin{array}{l}-0.025 \\
(-0.09)\end{array}$ & $\begin{array}{l}-0.053^{* * *} \\
(-3.91)\end{array}$ & $\begin{array}{l}-0.133^{* *} \\
(-2.00)\end{array}$ & $\begin{array}{l}-0.221 \\
(-0.46)\end{array}$ & $\begin{array}{l}-0.087^{* * *} \\
(-3.90)\end{array}$ \\
\hline$Q_{t-1}$ & $\begin{array}{l}0.016^{* * *} \\
(5.72)\end{array}$ & $\begin{array}{l}0.016^{* * *} \\
(5.80)\end{array}$ & $\begin{array}{l}0.017^{* * *} \\
(6.02)\end{array}$ & $\begin{array}{l}0.018^{* * *} \\
(4.81)\end{array}$ & $\begin{array}{l}0.018^{* * *} \\
(4.85)\end{array}$ & $\begin{array}{l}0.019^{* * *} \\
(4.99)\end{array}$ & $\begin{array}{l}0.014^{* * *} \\
(3.29)\end{array}$ & $\begin{array}{l}0.014^{* * *} \\
(3.32)\end{array}$ & $\begin{array}{l}0.015^{* * *} \\
(3.51)\end{array}$ \\
\hline Topshare & $\begin{array}{l}0.025^{*} \\
(1.80)\end{array}$ & $\begin{array}{l}0.023^{*} \\
(1.70)\end{array}$ & $\begin{array}{l}0.025^{*} \\
(1.82)\end{array}$ & $\begin{array}{l}0.001 \\
(0.06)\end{array}$ & $\begin{array}{l}0.001 \\
(0.07)\end{array}$ & $\begin{array}{l}0.004 \\
(0.22)\end{array}$ & $\begin{array}{l}0.100^{* * *} \\
(3.62)\end{array}$ & $\begin{array}{l}0.101^{* * *} \\
(3.64)\end{array}$ & $\begin{array}{l}0.098^{* * *} \\
(3.54)\end{array}$ \\
\hline Director & $\begin{array}{l}0.009 \\
(1.40)\end{array}$ & $\begin{array}{l}0.010 \\
(1.54)\end{array}$ & $\begin{array}{l}0.008 \\
(1.37)\end{array}$ & $\begin{array}{l}0.003 \\
(0.32)\end{array}$ & $\begin{array}{l}0.003 \\
(0.39)\end{array}$ & $\begin{array}{l}0.001 \\
(0.15)\end{array}$ & $\begin{array}{l}0.011 \\
(1.07)\end{array}$ & $\begin{array}{l}0.012 \\
(1.19)\end{array}$ & $\begin{array}{l}0.012 \\
(1.26)\end{array}$ \\
\hline Indepen & $\begin{array}{l}0.018 \\
(0.65)\end{array}$ & $\begin{array}{l}0.013 \\
(0.48)\end{array}$ & $\begin{array}{l}0.016 \\
(0.58)\end{array}$ & $\begin{array}{l}0.021 \\
(0.66)\end{array}$ & $\begin{array}{l}0.013 \\
(0.40)\end{array}$ & $\begin{array}{l}0.017 \\
(0.54)\end{array}$ & $\begin{array}{l}-0.016 \\
(-0.28)\end{array}$ & $\begin{array}{l}-0.008 \\
(-0.15)\end{array}$ & $\begin{array}{l}-0.011 \\
(-0.20)\end{array}$ \\
\hline Bsize & $\begin{array}{l}0.027^{* *} \\
(2.56)\end{array}$ & $\begin{array}{l}0.024^{* *} \\
(2.23)\end{array}$ & $\begin{array}{l}0.025^{* *} \\
(2.40)\end{array}$ & $\begin{array}{l}0.023^{*} \\
(1.86)\end{array}$ & $\begin{array}{l}0.020 \\
(1.63)\end{array}$ & $\begin{array}{l}0.022^{*} \\
(1.74)\end{array}$ & $\begin{array}{l}0.027 \\
(1.33)\end{array}$ & $\begin{array}{l}0.026 \\
(1.27)\end{array}$ & $\begin{array}{l}0.028 \\
(1.38)\end{array}$ \\
\hline CEOage & $\begin{array}{l}-0.070^{* * *} \\
(-4.65)\end{array}$ & $\begin{array}{l}-0.074^{* * *} \\
(-4.92)\end{array}$ & $\begin{array}{l}-0.073^{\text {*** }} \\
(-4.85)\end{array}$ & $\begin{array}{l}-0.078^{\text {*** }} \\
(-4.08)\end{array}$ & $\begin{array}{l}-0.079^{\text {*** }} \\
(-4.15)\end{array}$ & $\begin{array}{l}-0.078^{* * *} \\
(-4.10)\end{array}$ & $\begin{array}{l}-0.042 \\
(-1.64)\end{array}$ & $\begin{array}{l}-0.047^{*} \\
(-1.86)\end{array}$ & $\begin{array}{l}-0.048^{*} \\
(-1.91)\end{array}$ \\
\hline CEOtenure & $\begin{array}{l}0.001 \\
(0.23)\end{array}$ & $\begin{array}{l}0.000 \\
(0.09)\end{array}$ & $\begin{array}{l}0.000 \\
(0.07)\end{array}$ & $\begin{array}{l}-0.003 \\
(-0.57)\end{array}$ & $\begin{array}{l}-0.004 \\
(-0.72)\end{array}$ & $\begin{array}{l}-0.004 \\
(-0.72)\end{array}$ & $\begin{array}{l}0.009 \\
(1.02)\end{array}$ & $\begin{array}{l}0.009 \\
(1.01)\end{array}$ & $\begin{array}{l}0.009 \\
(0.96)\end{array}$ \\
\hline CEOShare & $\begin{array}{l}1.315^{* * *} \\
(7.02)\end{array}$ & $\begin{array}{l}1.321^{* * *} \\
(7.04)\end{array}$ & $\begin{array}{l}1.349^{* * *} \\
(7.18)\end{array}$ & $\begin{array}{l}1.714^{* *} \\
(2.29)\end{array}$ & $\begin{array}{l}1.813^{* *} \\
(2.42)\end{array}$ & $\begin{array}{l}1.989^{* * *} \\
(2.66)\end{array}$ & $\begin{array}{l}1.174^{* * *} \\
(5.51)\end{array}$ & $\begin{array}{l}1.186^{* * *} \\
(5.54)\end{array}$ & $\begin{array}{l}1.166^{* * *} \\
(5.44)\end{array}$ \\
\hline $\mathrm{CF}$ & $\begin{array}{l}0.062^{* * *} \\
(8.19)\end{array}$ & $\begin{array}{l}0.065^{* * *} \\
(8.65)\end{array}$ & $\begin{array}{l}0.065^{* * *} \\
(8.60)\end{array}$ & $\begin{array}{l}0.067^{* * *} \\
(6.80)\end{array}$ & $\begin{array}{l}0.071^{* * *} \\
(7.13)\end{array}$ & $\begin{array}{l}0.070^{* * *} \\
(7.03)\end{array}$ & $\begin{array}{l}0.0568^{* * *} \\
(4.72)\end{array}$ & $\begin{array}{l}0.059^{* * *} \\
(5.01)\end{array}$ & $\begin{array}{l}0.060^{* * *} \\
(5.03)\end{array}$ \\
\hline Sales t-1 & $\begin{array}{l}0.006^{* * *} \\
(5.55)\end{array}$ & $\begin{array}{l}0.013^{* * *} \\
(11.71)\end{array}$ & $\begin{array}{l}0.008^{* * *} \\
(6.49)\end{array}$ & $\begin{array}{l}0.005^{* * *} \\
(3.36)\end{array}$ & $\begin{array}{l}0.011^{* * *} \\
(7.92)\end{array}$ & $\begin{array}{l}0.006^{\text {*** }} \\
(3.91)\end{array}$ & $\begin{array}{l}0.008^{* * *} \\
(4.24)\end{array}$ & $\begin{array}{l}0.015^{* * *} \\
(8.42)\end{array}$ & $\begin{array}{l}0.010^{* * *} \\
(5.05)\end{array}$ \\
\hline Roa & $\begin{array}{l}0.416^{\text {*** }} \\
(10.77)\end{array}$ & $\begin{array}{l}0.390^{* * *} \\
(10.09)\end{array}$ & $\begin{array}{l}0.410^{* * *} \\
(10.57)\end{array}$ & $\begin{array}{l}0.456^{\text {*** }} \\
(9.32)\end{array}$ & $\begin{array}{l}0.428^{* * *} \\
(8.74)\end{array}$ & $\begin{array}{l}0.450^{* * *} \\
(9.16)\end{array}$ & $\begin{array}{l}0.310^{* * *} \\
(4.84)\end{array}$ & $\begin{array}{l}0.289^{* * *} \\
(4.49)\end{array}$ & $\begin{array}{l}0.307^{* * *} \\
(4.76)\end{array}$ \\
\hline Size & $\begin{array}{l}0.045^{* * *} \\
(18.48)\end{array}$ & $\begin{array}{l}0.042^{* * *} \\
(17.51)\end{array}$ & $\begin{array}{l}0.042^{* * *} \\
(17.43)\end{array}$ & $\begin{array}{l}0.046^{\text {*** }} \\
(15.64)\end{array}$ & $\begin{array}{l}0.043^{* * *} \\
(14.89)\end{array}$ & $\begin{array}{l}0.044^{* * *} \\
(15.00)\end{array}$ & $\begin{array}{l}0.044^{* * *} \\
(10.03)\end{array}$ & $\begin{array}{l}0.041^{* * *} \\
(9.43)\end{array}$ & $\begin{array}{l}0.039^{* * *} \\
(9.07)\end{array}$ \\
\hline Market & $\begin{array}{l}-0.011^{\text {*** }} \\
(-9.85)\end{array}$ & $\begin{array}{l}-0.011^{* * *} \\
(-9.98)\end{array}$ & $\begin{array}{l}-0.011^{\text {*** }} \\
(-9.98)\end{array}$ & $\begin{array}{l}-0.013^{\text {*** }} \\
(-9.21)\end{array}$ & $\begin{array}{l}-0.013^{\text {*** }} \\
(-9.35)\end{array}$ & $\begin{array}{l}-0.013^{* * *} \\
(-9.28)\end{array}$ & $\begin{array}{l}-0.008^{* * *} \\
(-4.40)\end{array}$ & $\begin{array}{l}-0.008^{* * *} \\
(-4.56)\end{array}$ & $\begin{array}{l}-0.008^{* * *} \\
(-4.63)\end{array}$ \\
\hline Industry dummy & Included & Included & Included & Included & Included & Included & Included & Included & Included \\
\hline Year dummy & Included & Included & Included & Included & Included & Included & Included & Included & Included \\
\hline Adjusted $\mathrm{R}^{2}$ & 0.1249 & 0.1197 & 0.1187 & 0.1244 & 0.1196 & 0.1195 & 0.1307 & 0.1238 & 0.1213 \\
\hline Observations & 10,451 & 10,451 & 10,451 & 6945 & 6945 & 6945 & 3506 & 3506 & 3506 \\
\hline
\end{tabular}

short-term and long-term loan ratios are negatively correlated with investment. The negative correlations are much stronger for firms with low growth. We also find that the higher the long-term loan ratios in firms' total bank loans are, the weaker the negative relation between firms' bank loan ratios and investment is. What is more, the negative relation between short-term loan ratios and investment is weaker for SOEs than for non-SOEs. However there is no difference between these two types of firms in the relation between long-term loan ratios and investment. Finally, we show that the reform of China's banking system in 2003 has not strengthened the negative relation between bank loans and investment.

Overall, our results imply that Chinese state-owned banks still play a disciplining role in Chinese publicly listed firms even though their leading decisions are severely intervened by government policies. In particular, firms with low growth are monitored by Chinese state-owned banks, but this disciplining role is mainly imposed through short-term loans. However, in regard to short-term bank loans, Chinese state-owned banks impose a weaker disciplining role in SOEs than non-SOEs. 


\section{Appendix A}

This table shows the detail definition of all key variables in our regression models.

\begin{tabular}{|c|c|}
\hline Variables & Definition \\
\hline Investment & The ratio of net capital expenditure to lagged fixed assets \\
\hline Debt $_{\mathrm{t}-1}$ & The lagged ratio of total bank loans to book value of total assets \\
\hline Sdebt $_{\mathrm{t}-1}$ & The lagged ratio of short-term loans to book value of total assets \\
\hline Ldebt $_{\mathrm{t}-1}$ & The lagged ratio of long-term loans to book value of total assets \\
\hline $\mathrm{DM}_{\mathrm{t}-1}$ & The lagged ratio of long-term loans to total bank loans \\
\hline Nature & Dummy variable, 1 if the ultimate controller of a firm is an individual and 0 otherwise \\
\hline$Q_{t-1}$ & $\begin{array}{l}\text { The lagged Tobin's } \mathrm{Q} \text {, which is calculated as the market value of common stock plus the book value of debt divided by } \\
\text { the book value of total assets. The book value per share is used as a proxy for the market value of non-tradable shares }\end{array}$ \\
\hline Growth & The average of net sales growth from $t-2$ to $t-1$ and from $t-1$ to $t$ \\
\hline Topshare & Shareholdings of the largest shareholder \\
\hline Director & Dummy variable, 1 if CEO is the chairman and 0 otherwise \\
\hline Indepen & The percentage of the independent directors in the board \\
\hline Bsize & The nature logarithm of board size \\
\hline CEOage & The nature logarithm of CEO age \\
\hline CEOtenure & The nature logarithm of CEO tenure plus 1 \\
\hline CEOShare & CEO shareholdings \\
\hline $\mathrm{CF}$ & The ratio of the operating cash flow to lagged fixed assets \\
\hline Sales t-1 & The lagged ratio of sales to lagged fixed assets \\
\hline Roa & The ratio of net profits to book value of total assets \\
\hline Size & The nature logarithm of total assets \\
\hline Market & Regional marketization level index, high scores of the index suggest good institutional development \\
\hline
\end{tabular}

\section{References}

Ahn, S., Denis, D. J., \& Denis, D. K. (2006). Leverage and investment in diversified firms. Journal of Financial Economics, 79, $317-337$.

Aivazian, V., Ge, Y., \& Qiu, J. (2005). The impact of leverage on firm investment: Canadian evidence. Journal of Corporate Finance, 11, $277-291$.

Alicia, G., Sergio, G., \& Daniel, S. (2006). China's banking reform: an assessment of its evolution and possible impact. CESifo Economic Studies, 52, $304-363$.

Allen, F., Qian, J., \& Qian, M. (2005). Law, finance and economic growth in China. Journal of Financial Economics, 77, 57-116.

Ayyagari, M., Demirguc-Kunt, A., \& Maksimovic, V. (2010). Formal versus informal finance: Evidence from China. Review of Financial Studies, 23, 3048-3097.

Bai, C., Liu, Q., Lu, J., Song, F. M., \& Zhang, J. (2004). Corporate governance and market valuation in China. Journal of Comparative Economics, 32, 599-616.

Barth, J. R., Caprio, G., Jr., \& Levine, R. (2004). Bank supervision and regulation: What works best? Journal of Financial Intermediation, 13, 205-248.

Berger, A. N., Hasan, I., \& Zhou, M. (2009). Bank ownership and efficiency in China: What will happen in the world's largest nation? Journal of Banking and Finance, $33,113-130$.

Bhabra, H., Liu, T., \& Tirtiroglu, D. (2008). Capital structure choice in a nascent market: Evidence from listed firms in China. Financial Management, 37, $341-364$. Booth, L., Aivazian, V., Demirguc-Kunt, A., \& Maksimovic, V. (2001). Capital structures in developing countries. Journal of Finance, 56, 87-130.

Brandt, L., \& Li, H. B. (2003). Bank discrimination in transition economies: Ideology, information or incentives? Journal of Comparative Economics, 31, 387-413.

Chen, S., Sun, Z., Tang, S., \& Wu, D. (2011). Government intervention and investment efficiency: Evidence from China. Journal of Corporate Finance, $17,259-271$.

Chow, C., Song, F., \& Wong, K. (2010). Investment and the soft budget constraint in China. International Review of Economics and Finance, $19,219-227$.

Cull, R., \& Xu, L. C. (2003). Who gets credits? The behavior of bureaucrats and state banks in allocating credit to Chinese state-owned enterprises. Journal of Development Economics, 71, 533-559.

Delcoure, N. (2007). The determinants of capital structure in transitional economies. International Review of Economics and Finance, 16, 400-415.

Demirguc-Kunt, A., \& Maksimovic, V. (1999). Institutions, financial markets, and firm debt maturity. Journal of Financial Economics, 54, 295-336.

Denis, D. J., \& Denis, D. K. (1993). Managerial discretion, organizational structure, and corporate performance: A study of leveraged recapitalizations. Journal of Accounting and Economics, 16, 209-236.

Diamond, D. (1984). Financial intermediation and delegated monitoring. Review of Economic Studies, 51, $393-414$

Diamond, D. (2004). Presidential address, committing to commit: Short-term debt when enforcement is costly. Journal of Finance, 59, $1447-1479$.

Dinc, I. S. (2005). Politicians and banks: Political influences on government-owned banks in emerging markets. Journal of Financial Economics, 77, 453-479.

Dobson, W., \& Kashyap, A. K. (2006). The contradiction in China's gradualist banking reforms. Brookings Papers on Economic Activity, 2, $103-162$.

Dong, J., \& Gou, Y. (2010). Corporate governance structure, managerial discretion, and the R\&D investment in China. International Review of Economics and Finance, $19,180-188$.

Fan, G., \& Wang, X. (2012). The 2011 report on the relative process of marketization of each region in China. Economics Science Press (in Chinese).

Farrell, D., Susan, L., Jaeson, R., Fabrice, M., Niyati, G., \& Greenberg, Ezra (2006). Putting China's capital to work: The value of financial system reform. Working paper: McKinsey Global Institute.

Firth, M., Lin, C., \& Wong, S. (2008). Leverage and investment under a state-owned bank lending environment: Evidence from China. Journal of Corporate Finance, $14,642-653$.

Fu, Xiaoqing, \& Heffernan, S. (2009). The effects of reform on China's bank structure and performance. Journal of Banking and Finance, 33, 39-52.

Garcia-Herrero, A., Gavila, S., \& Santabarbara, D. (2006). China's banking reform: An assessment of its evolution and possible impact. CESifo Economic Studies, 52, 304-363.

Gaver, J., \& Gaver, K. (1993). Additional evidence on the association between the investment opportunity set and corporate financing, dividend, and compensation polices. Journal of Accounting and Economics, 16, 125-160.

Ge, Y., \& Qiu, J. P. (2007). Financial development, bank discrimination and trade credit. Journal of Banking and Finance, 31, 513-530.

Giannetti, M. (2003). Do better institutions mitigate agency problems? Evidence from corporate finance choices. Journal of Financial and Quantitative Analysis, 38, $185-212$.

Goyal, V., Lehn, K., \& Racic, S. (2002). Growth opportunities and corporate debt policy: The case of the U.S. defense industry. Journal of Financial Economics, 64, 35-59.

Hart, O., \& Moore, J. (1995). Debt and seniority: An analysis of the role of hard claims in constraining management. American Economic Review, 85, 567-585.

Huang, G., \& Song, F. (2006). The determinants of capital structure: Evidence from China. China Economic Review, 17, 14-36.

Jensen, M. C. (1986). Agency costs of free cash flow, corporate finance, and takeovers. American Economic Review, 76, 323-329. 
Jung, K., Kim, U. C., \& Stulz, R. M. (1996). Timing, investment opportunities, managerial discretion, and the security issue decision. Journal of Financial Economics, $42,159-185$.

Khwaja, A., \& Mian, A. (2005). Do lenders favor politically connected firms? Rent provision in an emerging financial market. Quarterly Journal of Economics, 120 , $1371-1411$

Kornai, J., Maskin, E., \& Roland, G. (2003). Understanding the soft budget constraint. Journal of Economic Literature, 41, 1095-1136.

Kudrna, Z. (2007). Banking reform in China: Driven by international standards and Chinese specifics. Working paper.

La Porta, R., López de Silanes, F., \& Shleifer, A. (2002). Government ownership of banks. Journal of Finance, 57, 265-301.

La Porta, R., Lopez-de-Silanes, F., Shleifer, A., \& Vishny, R. (1997). Legal determinants of eternal finance. Journal of Finance, 52, 1131-1150.

Lang, L., Ofek, E., \& Stulz, R. M. (1996). Leverage, investment and firm growth. Journal of Financial Economics, 40, 3-29.

Levine, R. (1997). Financial development and economic growth: Views and agenda. Journal of Economic Literature, 35, 688-726.

Levine, R. (2002). Bank-based or market-based financial systems: Which is better? Journal of Financial Intermediation, 11, 1-30.

Li, Kai, Yue, Heng, \& Longkai, Zhao (2009). Ownership, institutions, and capital structure: Evidence from Chinese firms. Journal of Comparative Economics, 37, 471-490.

Lin, X., \& Zhang, Y. (2009). Bank ownership reform and bank performance in China. Journal of Banking and Finance, 33, $20-29$.

McConnell, J. J., \& Servaes, H. (1995). Equity ownership and the two faces of debt. Journal of Financial Economics, 39, 131-157.

Modigliani, F., \& Miller, M. H. (1958). The cost of capital, corporation finance, and the theory of investment. American Economic Review, 53, 433-443.

Morck, R., Yueng, B., \& Yu, W. (2000). The information content of stock market: Why do emerging markets have synchronous stock price movement? Journal of Financial Economics, 58, 215-220.

Myers, S. (1977). Determinants of corporate borrowing. Journal of Financial Economics, 5, 147-175.

Park, A., \& Sehrt, K. (2001). Tests of financial intermediation and banking reform in China. Journal of Comparative Economics, 29, 608-644.

Peyer, U. C., \& Shivdasani, A. (2001). Leverage and internal capital markets: Evidence from leveraged recapitalizations. Journal of Financial Economics, 59, 477-515.

Qian, J., \& Strahan, P. (2007). How laws and institutions shape financial contracts: The case of bank loans. Journal of Finance, 62, $2803-2834$.

Rajan, R. (1992). Insiders and outsiders: The choice between informed and arm's-length debt. Journal of Finance, 47, 1367-1400.

Rajan, R., \& Zingales, L. (1995). What do we really know about capital structure? Some evidence from international data. Journal of Finance, 50, $1421-1460$.

Sapienza, P. (2004). The effects of government ownership on bank lending. Journal of Financial Economics, 72, 357-384.

Smith, C., \& Watts, R. (1992). The investment opportunity set and corporate financing, dividend, and compensation polices. Journal of Financial Economics, 32, $263-292$.

Stulz, R. M. (1990). Managerial discretion and optimal financing policies. Journal of Financial Economics, 26, 3-27.

Tian, L., \& Estrin, S. (2007). Debt financing, soft budget constraints, and government ownership: Evidence from China. Economics of Transition, $15,461-481$.

Wang, Q., Wong, T. J., \& Xia, L. (2008). State ownership, the institutional environment, and auditor choice: Evidence from China. Journal of Accounting and Economics, 46, 112-134.

Zhou, X. C. (2004). Some issues concerning the reform of the State-owned commercial banks. Speech by the Governor of the People's Bank of China, at the IIF Spring Membership Conference, Shanghai, April 16. 